\title{
Probleemgestuurd leren als kennisconstructie
}

Citation for published version (APA):

de Grave, W. S. (1998). Probleemgestuurd leren als kennisconstructie. [Doctoral Thesis, Maastricht University]. Datawyse / Universitaire Pers Maastricht. https://doi.org/10.26481/dis.19980604wg

Document status and date:

Published: 01/01/1998

DOI:

10.26481/dis.19980604wg

Document Version:

Publisher's PDF, also known as Version of record

\section{Please check the document version of this publication:}

- A submitted manuscript is the version of the article upon submission and before peer-review. There can be important differences between the submitted version and the official published version of record.

People interested in the research are advised to contact the author for the final version of the publication, or visit the DOI to the publisher's website.

- The final author version and the galley proof are versions of the publication after peer review.

- The final published version features the final layout of the paper including the volume, issue and page numbers.

Link to publication

\footnotetext{
General rights rights.

- You may freely distribute the URL identifying the publication in the public portal. please follow below link for the End User Agreement:

www.umlib.nl/taverne-license

Take down policy

If you believe that this document breaches copyright please contact us at:

repository@maastrichtuniversity.nl

providing details and we will investigate your claim.
}

Copyright and moral rights for the publications made accessible in the public portal are retained by the authors and/or other copyright owners and it is a condition of accessing publications that users recognise and abide by the legal requirements associated with these

- Users may download and print one copy of any publication from the public portal for the purpose of private study or research.

- You may not further distribute the material or use it for any profit-making activity or commercial gain

If the publication is distributed under the terms of Article $25 \mathrm{fa}$ of the Dutch Copyright Act, indicated by the "Taverne" license above, 
Probleemgestuurd leren als kennisconstructie 
1998 W.5 de Grave, Madstricht. The Netherlands ISBN 9053980474

Vormgeving en druk: Datamyse I Unversitaire Pers Maastricht 


\title{
Probleemgestuurd leren als kennisconstructie
}

\author{
Proefschrift
}

ter verkrijging van de graad wan doctor

aan de Universiteit Maastricht.

op gezag van de Rector Magnificus.

Prof.dr. A.C. Niewwenthuizen Kruseman

volgens het bestuit van het College van Decanen,

in het openbar te verdedigen op

donderdag 4 jun 1998 om 14.00 uur

door

Willem simon de Grave 


\section{Promotar}

Profdr. H.G. Schmidt

Co-promoror:

Dr. H.P.A. Boshuizen

Beaordelingscommissie:

Prof.dr. C.P.M. van der Vleuten (voorziter)

Brofdr. B.H.A.M. van Hour-Wolrers (Universiteit van Amstendam)

Prof.dr. G.. Kok

Dr. I.L. wan der Linden (Uniwersiteir Utrech)

Dr. J.H.C. Moust 
Voor Dinceke, Linda, Lawra, Joris, Niels en Lars Mijn Moeder 


\section{Inhoudsopgave}

Hootostuk 1

inleiding 7

Hoofdstuk 2

Probleemanalyse: Activatie van, en elaboratie op, voorkennis. en de effecten hiervan op het leren van nieuwe informatie 15

Hoofdstuk 3

Differentiële effecten van probleemanalyse in de kleine groep op het verwerken van tekst bij beginners en gevorderden 31

Hoofdstuk 4

Relatieve effectiviteit van probleemanalyse in de groep vergeleken met individuele probleemanalyse en activatie van voorkennis 43

Hoofolstuk 5

Eflecten van probleemanalyse in een kleine groep bij eerstejaars medische studenten 55

Hoofolstuk 6

Probleemgestuurd leren: Cognitieve en metacognitieve processen tijdens probleemanalyse 69

Hootolstuk 7

Problemanalyse als methode om misconcepties te identificeren

Hoofdstuk 8

Algemene discussie $\quad 111$

Samenvatting $\quad 121$
Summary 127
Literatuur 133
Appendix $1 \quad 147$
Appendix $2 \quad 147$
Dankwoord $\quad 155$
Curriculum vitae $\quad 157$


Hoofdstuk 1

Inleiding 


\section{Inleiding}

In meer recente onderwijsbenaderingen is er een toenemende belangstelling woor de sociale aspecren van het leren. In de prakrijk van het onderwijs, maar ook in het onderzoek daarvan word bijoorbedd nagegaan hoe de sociale aspecten van her leren belangrijke processen, zoals het zelf reguleren wan het leerproces en her construcren van betckenissen, beinvloeden. In deze opvartingen over her onderwijs en in her onderzock wan her leren worde uitgegaan van cen (sociaal)-construcrivistische benadering van het leren (Steffe \& Gale, 1995). Uitgangspunt van deze manier van denken over onderwijzen en leren is dar studenten acrief hun eigen kennis en begrip varn de leerstof construeren, vooral door interactie met anderen.

Her constructieve karakter van het leerproces blijkt uit het feit dat lerenden de nieuw te leven lecrstof interpreteren in termen van wat ze reeds weten en dac ze proberen deze nieuwe informatie actief te relateren an de bestaande kennis die hen het meest relevant lijkt. I's er geen relevante voorkennis, of wordt deze niet als zodanig herkend, dan kan de lerende in principe wee wegen bewandelen; zelf iers bedenken of de nieuwe leerstof uit het hoofd leren. Dit uit her hoofd leren is echter een onvoldoende voorwaarde voor leren. Her leren wan een tekst betekent her activeren van de voorkennis en bewust relaties leggen tussen de nieuwe informatie en de voorkennis. Alleen hierdoor zal deze kennis larer ook bruikbaar zijn in nieuwe situaties. Leerlingen acriveren echter walk onvoldoende de voorkennis en leggen vaak niet spontaan relaties tussen de nieuw te leren leerstof en bestaande voorkennis, vooral als her wetenschappelijke teksten betreft, tenzij de lerenden hiertoe bewust gestimuleerd worden (Ali, 1990; King, 1992). Dit leggen van relaties russen wat men al weet en het nieuwe wordt elaboreren genoemd. Wanneer men als uirgangspunt heef dat leren een actief proces is, dan is een essentieel kenmerk van cen onderwijsstrategie de lerende te activeren. Dit acriveren kan bevorderd worden door studenten zelf elaboraties te laten genereren.

Socialc intoractic russen leefrijdgenoten kan het genereren wan elaboraries sterk stimulcren. Champagne en Bunce (1991) constateerden dat: "Reports of the effects of incractions in ducarional setrings describe various conceptual changes, including claborarion of concepts, hecoming aware of one's owa learning process, taising cognirive level, and improving problem solving capabilities"(p. 30). Interactie russen lectijdgenowen is verder van belang ondar de afstand in begrip van deleerstolt tussen de studernten onderling veel kleiner is dan die tussen studenten en de docent, watdoor communicatic van ideeën wordt vergemakkelijkt.

De beteken is voor het onderwijs van deze oncwikkelingen in de psychologie van het leren wind men onder andere terug in de onderwijsbenadering die probleemgestuud leren genoend wordt. In kleine groepen wordt studenten gevratagd op basis van ecn probleem hun woorkennis te activeren en hierop in de groep gezamenlijk te elaboreren, zodat zij op een actieve wijze een relatie leggen russen de 
voorkennis en de nieuw te leren informanie: zelfsudie vult dan verwolgens leemten in de kennis an. In dit proefschrift staar de eerste fase van het proces van problecmgestuurd leren centraal, namelijk de probleemandyse die voorafgaat an de feitelijke studie. Problemanalyse is de fase warin studenten verklaringen genereren voor een voorgelegd probleem. Er is echrer nog weing bekend over de effecren van probleemanalyse in de kleine groep op het leren van nicuwe informatie. Eveneens is er weinig onderzoek gedaan naar de cognitieve processen rijdens deze probleemanalyse, die een verklaring kunnen bieden woor de gevonden effecten.

De centrale vragen van dit proefschrift kunnen als volge worden getormuleerd: "War zijn de effecren van probleemanalyse in de kleine groep op het leren wan nieuwe informatie in een studieteks?" en "Welke cognitieve processen kunnen worden waargenomen tijdens de probleemanalyse?" Doel van de studies die in dit proefschrift gepresenteerd worden is een verdere cmpirische onderbouwing te bieden voor één wan de claims van probleemgestuurd leren, namelijk de claim dat probleengestuurd leren leidt tot het beter leren en onthouden van de nieuwe informatic (Barrows, 1984; Schmidt, 1993).

In dir hoofdsruk wordt allereerst aangegeven wat de plaats is van probleemanalyse in de kleine groep binnen het proces van probleemgestururd leren. Vervolgens wordt probleemanalyse in het kort beschreven en worden de funcries ervan verhelderd. Tenslorte wordt een schers gegeven van her in dir proefschrift te presenteren onderzoek.

\section{Probleemgestuurd leren in een onderwijsgroep}

Probleemgestuurd leren is een onderwijsanpak die haar wortels heeft in de "discovery learning" benadering en in de "case method" benadering (Schmidr, 1984). Het is een onderwijsleermethode die begint met een speciaal voor onderwijsdoeleinden geconstrueerd probleem, dat wan praktische of theoretische ard kan zijn. Onder een probleem word verstaan cen min of meer neurralk beschrijving van een aantal verschijnselen of gebeurtenissen die in een zekere relave met olkar lijken te stan (Schnidt, 1983). De studenten in de kleine groep hebben tot taak dit probleem (indien nodig) re definëren en verklaringen voor dit probleen te bedenken. Daarbij makk men gebruik van de anwerige workennis on dexe verklaringen te genereren. Tijdens dit construeren wan verklaringen kunnen er wagen opkomen en leerntes in kennis gesignaleerd worden. Deze vagen en geconstatecrde leemres vormen de aanleiding om in de groep lecrdoclen te formuleren. Deze leerdoelen zijn richtinggevend voor de individucle studie gedurende de volgende dagen. Voor deze zelfstudie makt men gebruik van een variatic aan informariebronnen. Na deze periode van zelfstudic komt men weer in de groep bijeen om over het geleerde mondeling te rapporteren (xie voor uitgebreide beschrijwingen 
van her proces van problcemgesruurd leren Barrows \& Tamblyn, 1980; Moust, Bouhuijs, \& Schmidt, 1989; Schmidt, 1983; 1993).

\section{Probleemanalyse: beschrijving en functie}

Een kenmerk van probleemgestuurd leren is dat een probleem niet wordt voorgelegd nadar gestudeerd is, maar dat men her voorafgasonde aan de studie gepresenteerd krijgt. Dit probleem dient men re analyseren. Een concrete beschrijving van war daarbij gebeurt, kan wellich helpen bij het verduidelijken wan de functie van deze activiteit. De analyse van het probleem over het gedrag van een rode bloedcel in twee verschillende milieus door lcerlingen van de derde klas van het WWO (Schmidt, 1982) wordt hier als voorbeeld gebruikt. Dit "bloedcel" probleem is gebruikt in een aantal studies die in dit proefschrift beschreven worden. Een excerpt uir een feirelijke probleemanalyse door cen groep lerenden illustreert de kenmerken van problecmanalyse. Het bloedcelprobleem ziet er als volgt uit:

Een rode bloedcel (een rood bloedlichaampje) wordr onder een microscoop in zuiver water gebracht. De bloedcel zwelt in korte rijd op en springt uireindelijk kapot. Een andere bloedcel wordt in een oplossing van zout in water gebracht. Hij schrompelt ineen. Hoe zijn deze verschijnselen te verklaren?

De leerlingen wordt dus gevraagd deze verschijnselen te verklaren. Bij de probleemanalyse gaat het erom dat de groepsleden nagaan wat men weet of denkt te weten over de processen en mechanismen die ten grondslag liggen aan het probleem. Bij het genereren van verklaringen kan ieder groepslid teruggrijpen op eigen voorkennis en/of de voorkennis van andere groepsleden en kan men proberen al redenerend iets meer te begrijpen. De voorkennis van de groepsleden kan verschillen wat betreft zekerheid, juistheid, volledigheid en aard. Tevens kunnen de grocpssleden variëren in de mate warin ze vaardigheid in het redeneren hebben. In her nu volgende excerpt van een protocol van een probleemanalyse vindt men voorbeclden van her genereren van verklaringen. Het betreft de analyse door leerlingen uit de derde klas van het wwo, die nog geen kennis hadden wan het onderwerp osmose, het onderwerp warnat her bloedcelprobleem verwijst.

In dit excerpt van een protocol wordt het constructieve en sociale karakter van het leerproces duidelijk. Verschillende verklaringen worden gegenereerd, verklaringen dic regenstrijdig kunnen zijn, on rkenningen van gegeven verklaringen en verw klaringen die voortbouwen op reeds gegeven verklaringen. Klat denkt bijvoorbeeld dat de oorzaak voor her kapot gaan van de bloedcel te maken heeft met iets dat in het water zit, maar geft nict aan wat dat is. Jos denkt met Klaas mee, bouwt daarop voort en noeme zuurstof in her water als mogelijke oorzaak. Tevens wordt 
Tabel 1.1. Excerpt ut een protocol van analyse wan he bloedceloroblem ultgewoerd toon leerlingen unt de derde klas van het wo.

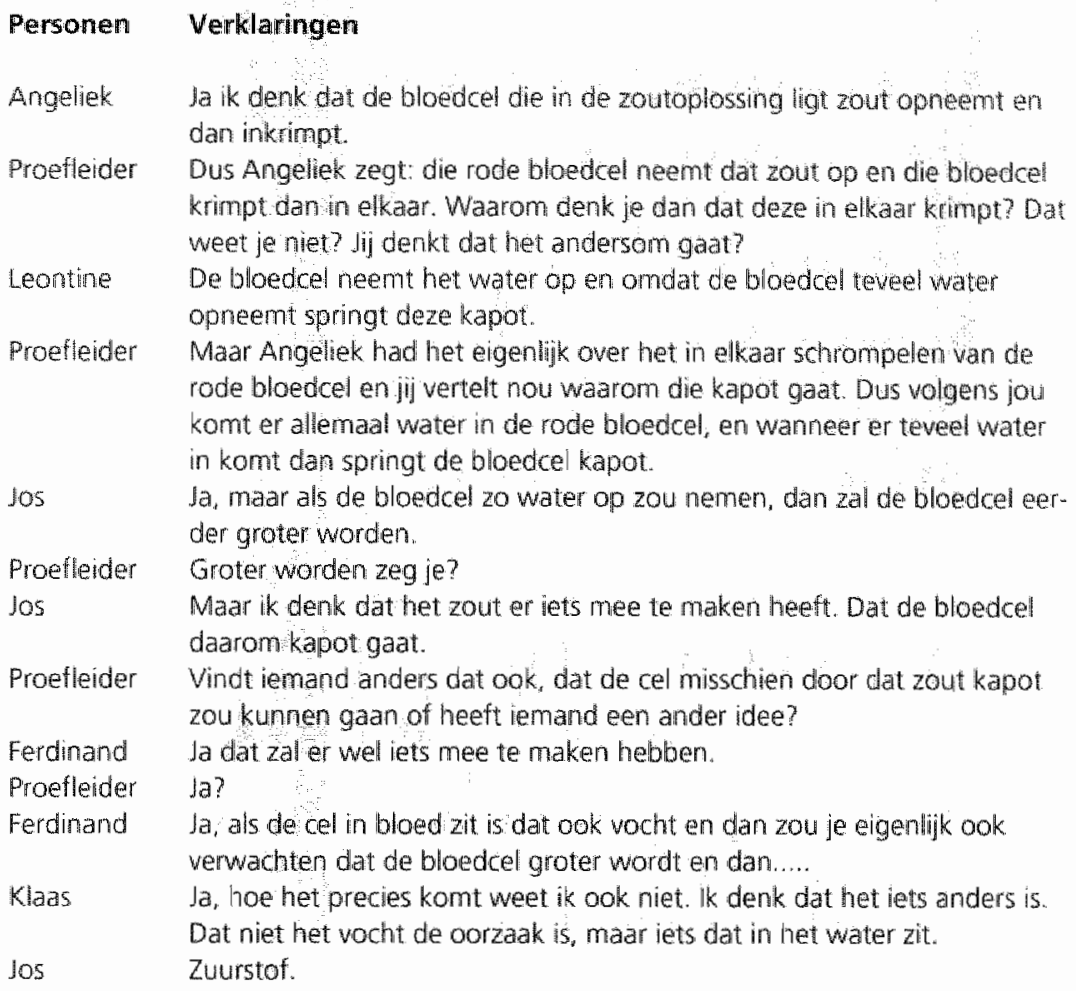

uir her excerpt duidelijk dat er ook onzekerheid is over her warheidsgehalte van de verklaringen, hergeen tot uiring komt in: "Ik denk dat..."; "Ik denk dat het iers anders is....". Tegelijkertijd is er een bewustwording van de leemtes in de voorkennis. "Ja hoe het precies komt weet ik ook niet". De leerlingen beperken zich nicr alleen tot de gegeven probleembeschrijuing maar proberen via gedachtenexperimc1.ten verder te komen: "Ja als de cel in bloed komt is dat ook vocht en dan zou jo eigenlijk ook verwachten dat de bloedcel groter wordt en dan..." Deze cognitieve processen, worden verondersteld van invloed te zijn op het leren wan nieuwe informatic. 


\section{Een schets van het in dit proefschrift te presenteren onderzoek}

In cen drietal cxperimenten werd onderzocht of de bypothese dat het genereren van verklaringen (problecmanalyse in een grocp) leidr tor her beter leren en onthouden var nicuwe informatie ondersteund wordt. Recente inzichren in de psychologie van het leren bieden ook aanknopingspunten voor meer gederaillecrde analyses van de cogniricve processen die platsvinden gedurende de cerste analyse van een probleem. In een tweetal vervolgonderzoken werd daarom de probleemanalyse aan een nader kwaliarief onderzoek onderworpen.

Hoofdstuk 2 geeft allereerst een overzicht van theorieen over de rol wan voorkenniis bij het leren van nieuwe informatie. Vervolgens wordt de relevante onderzockslitcratuur naar de effecten beschreven van aan probleemanalyse verwante taakstructuren op het leren van nicuwe informatie. Tenslotte wordt ingegaan op een mogelijke theoretische verklaring woor de effecten van probleemgestuurd leren, en wordt verslag gedxan van studies die effecten wan probleemanalyse in de kleine groep op her leren wan nieuwe informatie empirisch ondersteunen.

Hoofdstuk 3 rapporteer een experiment waarin differentiele effecten van problemanalyse op het verwerken van een studietekst bij beginners en gevorderden werden bestudeerd. Onderzocht werd wat de effecten van probleemanalyse zijn op de "free" en "cued recall" van de tekst. Bij de recall werd niet alleen gekeken naar het aantal correct herinnerde "proposities" maar ook naar het patroon van de recall. Hiertoe werd gebruik gemaakr van her onderscheid tussen verklarende en descriptieve proposities woor thet vaststellen van de mate van integratie van de nieuwe kennis in de reeds bestande kenmis.

In het vierde hoofdstuk wordt een experiment besproken warin wetd onderzocht of elaboratic, zoals geinduceerd door drie verschillende taken (aktivatie van woorkennis, individuele probleemanalyse, en problecmanalyse in een groep) differentiële effecten heeft op de recall. Als mat voor de tecall werd nier alleen genomen het antal correcre proposities dat in free recall protocollen kan worden teruggevonden; matr ook "cucd" recall. In dic onderroek werd ook gekeken naar het patroon wan de recall.

Her vijfde hoofdstuk presenteet een experiment watin werd onderzocht of de effecten van probleemanalyse op het zich herinneren van een probleem-relevante tekst ook te vinden zijn in ecn cologisch meer valide context. Deze context betreft een medisch curriculum gebaseerd op principes wan probleemgestuurd leren, met complexere leerstof en met proefpersonen dic feirelijk zijn getraind in probleemanalyse. Datarbij werd onderzoch wat de effecten zijn wan probleemanalyse op de reall (antal correcte proposicies herinnerd) en op her patroon van de recall (verklarend versus beschrijvende proposities herimnerd en het aancal inferenties herinnerd). 
Gaan her derde, vierde en vijfde hoofdtstuk over de effecten van problemanalyse op het leren en onthouden van een studierekst, de volgende twee hooflstukken behandelen diepre-analyses van her proces en het produkr van probleemanalyse. In Hoofdstuk 6 wordt een onderzoek gepresenteerd dat gerichr is op de cognitieve en metacognitieve processen die tijdens probleemanalyse bij studenten platsvinden. Als onderzoeksmerhode werd "srimulated recall" gebruikt. Daarbij werden hard-op-denk prococollen gegenereerd bij de observatie van een videoband van een probleemanalyse, waaraan de proefpersonen zojuist hadden deelgenomen. Naast her gebruik van een categoriesysteem voor het caregoriseren wan de propositics, gemaakr tijdens het proces van probleemanalyse, werd er nog een meer diepgaande analyse van her proces van conceptuele verandering uitgevoerd.

In Hoofdstuk 7 wordt cen onderzoek gepresenteerd dat, op basis van theorievorming over misconcepries, nagaat wat de functie is van probleemanalyse voor her signaleren van misconcepties over osmose en diffusie. De prorocollen van de probleemanalyse van her bloedcelprobleem werden daartoe geanalyseerd. De protocollen wan de beginners werden geanalyseerd in vergelijking tot de protocollen van de gevorderden.

In Hoofdstuk 8 worden de resultaten van de verschillende studies in dit proefschrift bediscussieerd; worden paden voor verder onderzock uitgezet; en worden praktische implicaties van het onderzoek voor het onderwijs beschreven. 

Hoofdstuk 2

Probleemanalyse als activatie van, en elaboratie op, voorkennis, en de effecten hiervan op het leren van nieuwe informatie 


\section{De rol van woorkennis bij leerprocessen}

Waarom is het analyseren van een probleem voorafgande an her feirelijk bestuderen wan studicteksten nu eigenlijk zinvol? De veronderstelling is dat door her acciveren van de voorkennis de nieuw te leren informatie in studieteksten beter geleerd wordt. Verder wordt verondersteld dar deze voorbereidende activiteiten leiden rot bepaalde cognitieve processen die de incegratie van de voorkennis mer de nieuw te leren informatie rot sand brengen. In her nu volgende gedeete wordt ingegan op deze cogniticve processen.

\section{Het belang wan wookennis}

Een veronderstelling dic ten grondslag ligt aan her onderzoek naar de rol van voorkennis in lecuprocessen is het belang ervan bij het begrijpen wan nieuwe informatie. Ecm onderzock dat dit belang illustreer is dat van Chiesi, Spilich en Voss $(1979)$. Zij onderzochen war proefpersonen, die verschilden in de hoeveetheid kennis over honkbal, leerden wan een rekst die over honkbal ging. Ze onderscheidden wee groepen, écn met veel en én mer weinig wookennis, en gebruikten darvoor een vagenlijs over honkbal. De groepen waren vergelijkbar in verbatc vardigheden. De tekst die ze ter besudering kregen voorge egd bestond uit een verslag van een ficrieve honkbalwedstrijd. Vervolgens werd hun gevraagd op te schrijwen wat ze van de inhoud van de tekst hadden onthouden. Tevens kregen ze daarna nog cen aantal aanvulvragen. Uit de resultaren bleek dat de proefpersonen met veel woorkennis zich meer herinnerden van de tekst en dar er duidelijke verschillen waren in het patroon van wat zij zich herinnerden. Proefpersonem met veel voorkennis herinnerden zich bijwoorbeld meer informatie die direcr gerelateerd was aan de doelen van her spel dan de proefpersonen met weinig voorkennis. Ook Perferti (1989) conchudeerde, op basis van een onderzoek naar de invloed van de niveaus van voorkennis met betrekking rot foorball op het onthouden van ecn cokst ower foorball. dat de mate wan woorkennis sterk van invloed is op wat men onthoud van de tekst. Dit effect heef nier alleen betrekling op de belangrijke informatic wit de tekst, maar ook op de minder belangrijke informatie.

In het onderzock naar her begrijpen en leren wan teksten is dus gebleken dat de kemis en ervaring dic ecn lerende met zich mebrengt voor een belangrijk deel bepralt wat, hoe en in welke mate de nieuwe informarie geleerd wordo (Wilson \& Anderson 1986). B3lijkbaar hange her begrijpen en herinneren van nieuwe informatie voor een belangrijk deel af van war we al weten. Een consequenrie hiervan is dat nicuwe informarie alloen begrepen kan worden als die nieuwe informatie aan de beschilkbare kennis gerelateerd words. 
Verklaringen woor de effecten van voorkennis

Verkaringen over de manier warop voorkennis her venwerken wan niouwe informatie beinvloed, zin gebaseerd op psychologische modellon woor her verwerken van informatie. Op basis van degelike modellen ain wershillende functios van voorkennis voor her leren wan neuwe informatie re onderscheiden (Alba 8 Hasw her, 1983; Anderson 1984: Anderson \& Pearson 1984: Brewer \& Nakamum. 1984; Mayer, 1989a; 1996; Wilson \& Anderson, 1986.

Allereerst word verondersteld dan de relevante kemnis watrowe men reats beschikt de andacht die men besteed an verschillende onderdeten van exu studierekst beinvloed. Dir wondt ook wel de selectiowandach byothow genoend (Aba \& Hasher, 1983; Brewer \& Nakamura, 1984; Wilson \& Andorson, 1986). De veronderstelling hierbij is dar de extrandache die belangrije (gezien vanuit de wookennis) tekstonderdelen onvangen, tot gevolg heef dar deze berer geleerd en on rhouden worden. Een onderzoek wan Pichere en Anderson (1977) illustrect deze selectieve andachrsfun krie van woorkennis. In hum experimen lazen groepen profpersonen dezelfde tekst vanuic dreverschillonde standpunen, die van huizenkoper, inbreker of hun eigen niet nader gespecificeerde standpunt. De rekst ging over twee spipbelende jongens die nar het huis wan én wan hen gingen. In de rekst werden allerlei zaken beschreven over her huis, zoals ligging, kenmorkon van de bouw en van de inboedel. Voor deze rekst was van revoren bepaald wat belangrijk zou kunnen zijn vanuit het standpunt van een inbreker, wan en huizenkoper, en van iemand die de tekst net wantit cen special standpunt las. Zo is bijvoorbeeld informarie over cen muntencollectic of een kleurencevisie bolangrijket woor de inbreker dan voor de huizenkoper. Het lekkende dak darentegen. zal de inbreker weinig interesseren. Uit wat de proefpersonen zich na het bestaderen van de rekst herinnerden, bleek dat er cen duidelijke relatic was ussen het belang van de rekstelementen (gezien vanuit cen bepaald perspectief) en wat men zich herin-

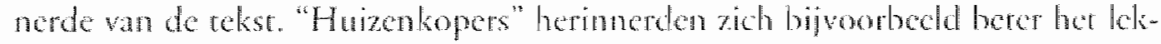
kende dak en minder goed de munenotlectic en de klewentevisio. Bij "inbre kers" was dir ongekernd.

Een andere hyporhese is dar woortennis ook een reker interpetatickado bieden

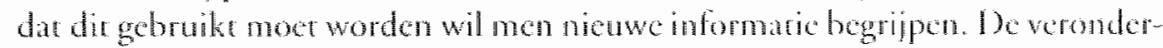

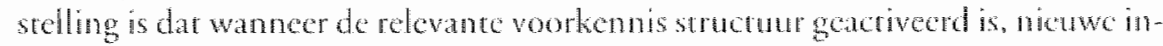
formate berer onthouden zal wonden dan nicuwe in formatic die nier an de voor-

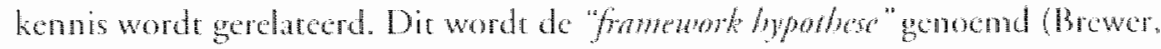
1987; Wilson \& Anderson, 1986). Fen onderock van Bransand en fohnson (1972) illusteer deze funcre van wookennis. In dio onderzok werd gebruikgemake van ambigue reksen. Proefpersonen waren over het algenecen niet in stata deze teksen te begripen of te herinneren. Een voorbed van wo netest is de volgende: 
The procedure is actually quite simple. First you arrange the items into different groups. Of course one pile may be sufficient depending on how much there is to do. If you have to go somewhere else due to lack of facilities that is the next step: otherwise, you are preny well set. It is important not to overdo things. That is, it is better to do too few things at once than too many. In the short tun this may not seem imporrant bur complicarions can easily arise. A mistake an be expensive as well. At first, the whole procedure will seem complicated. Soon, however, it will become just another facet of life. It is difficult to foresee any end to the necessity for this task in the immediate future, but then, one never can tell. After the procedure is completed one arranges the materials into different groups again. Then they can be pur into their appropriate places. Eventually they will be used once more and the whole cycle will then have to be repeated. However, that is part of life (Bransford \& Johnson, 1972).

Wanneer de proefpersonen een titel kregen voor een rekst als deze, bijvoorbeeld "washing clorhes", werd de tekst wel goed begrepen en herinnerd. Dit onderzoek toont aan dat voor her begrijpen van informatie belangrijk is dat men over een cognicieve structuur of kader beschike en dit acriveert, waardoor de relaries tussen de verschillende tekstonderdelen betekenis krijgen.

De kennis watarover men reeds beschikt, speelt niet alleen een rol bij het verwerven van nieuwe kennis, de aanwezige kennis heef daarnaast ook functies voor her terughalen ("retrieval") van geleerde informatic (Brewer \& Nakamura, 1984; Wilson \&. Anderson, 1986). Zo maakt de kennisstruccuur die men heeft systematische zockprocessen in her geheugen meer of minder goed mogelijk. Een kennisstructur die bijvoorbeeld hiërarchisch georganiseerd is kan als gids dienen voor her vinden van informatie die moet worden herinnerd. Volgens de "retriewat'plan hypothese" (Brewer \& Nakamura, 1984; Wilson \& Anderson, 1986) levert da kennisstructur her kader voor ecen top-down zoekproces wan het gehergen. Dit zockproces levent roegang tor informaric die belangrijk is in het licht van de geacriverde kennisstructur, mala kan geen informatie naar woren halen die niet gerdateerd is an de geacriverde kemisstructuar. Deze hyporhese zegr dus iers over de wegankelijkheid van de informatie in he lange termiin geheugen. Een dordo hypothese heetr te maken mer her feit dar geen enkele tekst volledig explicier is en informatie dic nodig is om de tekst volledig te begrijpen ontbreck vaak. De vook enmis van de lexer van de tekst levert chter de basis voot het maken van inferenties die verder gian dan de expliciere informatic in de rekst on her begrijpen wan de rekst mogelijk te maken. Mer andere woorden voorkennis scimuleert het produceren van claboraties (Anderson \& Pearson, 1984; Brewer \& Nakamura, 1984; Wilson \& Anderson, 1986). Elaboratie is het verrijken van informatie door her bedenken van relaties tussen ideeèn uir de tekst en de voor- 
kennis. Het resultaat hierwan zou een betere integratie vă de nicuwe informatie in de bestaande kennis zijn. De veronderstelling is bovendien dar claboratie leidt tor her uitbreiden van her anntal rerrievalpaden via welke de informatie weer wit her geheugen kan worden gehaald en daamee tot her beter onthouden van de informatie. Deze veronderstelde cognitieve processen en de daarbij behorende effecten wordt de "elaboratie hypothese" genoend (Reder, 1980; 1985; Reder, Charncy, \& Morgan, 1986). Er worden in de literatur vele vormen van elaboraties onderscheiden, zoals het bedenken van voorbeelden en analogieèn, her herformuleren van bepaalde zaken en her afleiden van deducties (Reder, Chamcy, \& Morgan, 1986).

Een voorbeeld van onderzock naar de invloed van elaboraties op het leven van een tekst is een studie van Mayer (1980). In een serie van vijf experimenten lazen proefpersonen een tekst over her progtammeren van een computer en gebruikten daarbij cén van de volgende leerstrategieèn: de eerste groep werd een concreet model over de computer gegeven voorafgaande aan het lezen en voor gebruik tijdens het lezen wan de tekst (Mayer noende dit de advance-organizer groep); de rweede groep kreeg na elke pagina van de tekst de instructie om uit te leggen hoe de tekst gerclateerd was aan een gegeven concreer model over de compurer (de model-elaboratie groep); de derde groep kreeg na elke pagina tekst de instructie om uir te leggen hoc de net geleerde telist gelijk of verschillend was an andere tekstgedeclten (de vergelijkende-elaboratie groep); de controle groep krecg alleen de rekst. Uit de resultaten van deze experimenten bleck dar de twee elaborarie groepen consistent betere resultaten behaalden in vergelijking met de twee andere condities wat betreft het zich herinneren van de belangrijke informatic uit de tekst, maar niet war betreft her zich herinneren van feirelijke informatie uir de rekst. Verder bleek dat de rwee elaboratie groepen betere resultaten behaalden wat betref het tocpassen van de geleerde kennis op nieuwe problemen, maar niet wat betreft prestaties op envoudige problemen.

\section{Voorkennis en verwerven van nieuwe informatie}

De theoricvorming over de rol van kannis heef zich volgens Rumethart en Norman (1978) vooral gericht op het leren van relarief eenvoudige informarie, watabij de relevante kennisschema's reeds aanwezig waren en slechts verder uirgebouwd werden. Fr zijn echter verschillende vormen van lenen (Rumethart, 1984; Vosniadou \& Brewer, 1987). Rumelhare (1984) onderscheide leren door "accretic", "herstructurering" en "runing". Met leren door accretie wordt bedocld een manier van leren warbij de relevante kennisstructuur rects anwezig is en deze kennisbasis toe neem door toevoegen van nieuwe concepten. Fr treden gech strucrurcle veranderingen in de kennis zelf op. Er is sprake van leren door herstructureren wanneer nieuwe kennisstructuren worden geconstrucerd op basis van de bestaande. Er is een herordening van concepten en wel zodanig dat geheel andere verklaringen 


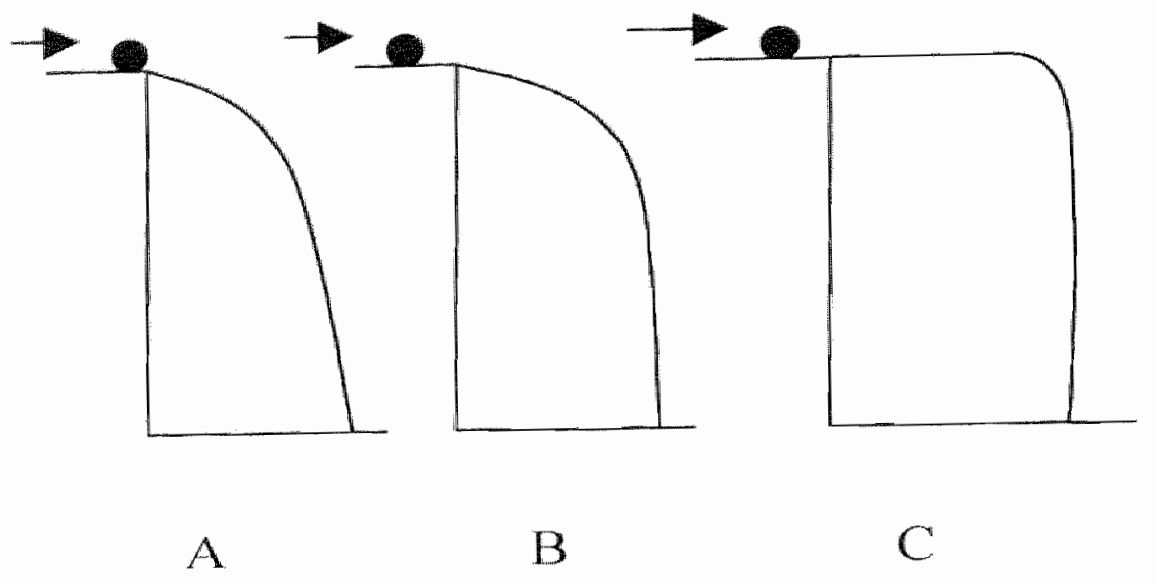

Figuur 2.1. Oplossingen van een expert (A) en twee beginers (B en $C$ ).

ontstaan. Leren door "funing" betekent dat geen structurele verandering van de kennisstucruur optecte maar her geleerde word atangevuld mer informatie die de roepassing ervan vergemakkelijkr, bijworbeeld informatie die aangeefo wanneer bepaalde kennis noet worden gebruikt. De theoricvorming over de rol wan vorkennis heeft zich vooral gericht op het leren door accretie. Veel minder is bekend over de rol van voorkennis bij de herstructurering van kennis.

Her onderzock dar is gedaan naar herstruciurering van kennis beperk zich ror de overgang van moviet nat expert en tot het ontsatan en in stand houden van misconcoptics. Vooral in het onderzock naar misconcepties is duidelijk geworden dat voorkennis niet alken cen positieve, maar ook een belemmerende invloed kan uitoefenen op herstructureren van kennis. Sudenten zijn, zoals gezegd, geen tabulae rasae, maar beschikken reeds over bepaalde voorkennis. In werschillende kennisgethelen is onderzock gedtan nar misconcepties, zoals, de wiskunde, de chemic en de biologie, matr vootal op her gehicd wan de marumktnde (Cardner, Ciremo. Reif, Schocnfeld, DiSessa, \& Sage, 1990; Pfundt \& Duit, 1994). Zo onderzocht McCloskcy (1983) verschillende misconcepties op her gebicd van de mechanica, zouls bet volgende probleem: de proctpersoon moet zich voorstellen dat

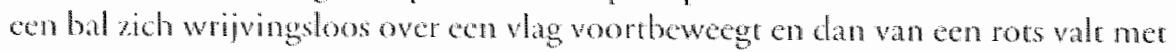
cen snetheid van 50 mph en moer dan de ban tekenen naar de grond. Het correcre ancwoond is een parabolische baan (Figur 2.1 , A), ondat de bal horizontaal bliff gatn met $50 \mathrm{mph}$ matar acelereert in de neergatande beweging die te wijten is ain zwartekrache (dir is de enige krachr die uirgeofend worde op de bal). Veel prodfersonen tekencn oen ruwe parabolische curve, maar sommige (ongeveer een kward rekenen een curve zoals die van panel $B$ of $C$. warin er een periode is van zuvere necraande beweging, soms volgend op een periode van zuwer horizontale 
beweging (C). De proefpersonen verklaren deze banen door te yeggen dat de krachr die de horizontale beweging veroorzakt afneent en dat de zwartekncht her dan overneemt. Deze misconcepries blijven bestaan ondanks her onderwijs dat men op desbetreffende gebied heeft gchad.

Uit onderzoek naar misconcepties blijk dar de kennis wan seholieren en studenten vaak bestaat uit een dun laagje vernis van formele kennis en rekenvardigheid. dau gemakkelijk werwijderd kan worden om ecn kern van incuitieve, a-werenschappeliike ideeën bloor te leggen (Striley, 1988). Wil een leerling werkelijk begrip kriigen van de leerstof dan is het essentieel dat er een integratie van de nieuwe kennis mer de reeds bestaande kennis tor stand komt. De onderwijs-leertheorieën die uir ther misconceprie-onderzoek zijn ontsram, benadrukken her belang van daboraries, zoals het genereren wan analogieen, het construeren van verklaringen en discussie in de groep (Biemans, 1997; Driver, Guesne, \& Tiberghien, 1985; Smith, DiSessa, \& Roschelle, 1994).

Door her misconceptie-onderzock is meer ken nis verkregen van her proces van inregrarie van nieuwe informatie in de bestande liemnis ca van het proces van conceptuele verandering bij lerenden en de voorwarden diarvoor. Zo onderzoch Clement (1989) dir leerproces via het construeren van een model, dat wil zeggen dat proefpersonen verklaringen moesten genereren voor een hen gepresenteerd probleem. Een voorbeeld thiervan is het veerprobleem (Clement, 1989, p.350):

Een gewicht wordt gehangen aan een veer. De oorspronkelijke veer wordt vervangen door een veer gemalke van herzelfde soort draad, mer hetzelfide aantal windingen, maar mer windingen die rwee keer zo breed zijn in diameter. Zal de veer meer, minder of in dezelfde mate uitrekken van haar natuurlijke lengte bij hetzelfde gewicht? (Veronderstel dat de massa van de veer verwaarloosbaar is in vergelijking rot de massa wan her gewicht). Wat denk je en warom?

Op basis van protocolanalyse van her hardop denken dat profpersonen rijdens her oplossen van dit rype problemen uitvoerden. concludecte Cloment dat de verschillende denkprocessen tijdens het genereren van verklaringen verdeck kunnen worden in twee hoofdeategoriën: het produktieve proces van het creèren en veranderen van verklaringen en her evaluatieve proces van her empirisch testen en rationele evaluatie. Deze twee processen incencteren. Bij het genereren wan verklatringen speelden analogieen een belangrijke rol, bij her evaluatieve proces anomalieèn. Tevens bleck uit dit onderzoek het belang van analoog redencren, her introduceren van anomalieën en evaluatieve processen wor het veranderen van misconcepries bij lerenden. 
Elaboratie en het genereren van verklaringen in een kleine groep Het werkelijk leren en begrijpen van wetenschappelijke reksten warin een bepaald mechanisme wordt uitgelegd, betekent dat niet alleen de constructie van een mentale representatie van de tekst vereist is, maar ook moet er elaboratie platsvinden (Kinrsch \& Kintsch, 1995). Dir betekent dat er een mentale representatie van de rekst geconstrueerd moet worden die ingebed is in de voorkennis van de lezer. Verschillende cognirieve processen kunnen een rol spelen bij de constructie van cen dergelijk mentaal model. Mayer (1996) benoeme deze als volgt: Het selecteren van relevante informatie, her organiseren van de geselecteende informatic in ecn coheren gehecl en tenslotte de integratie van de nieuwe informatie met de voorkennis. Daar kome nog bij dat studenten moeten leren deze cogniricve processen te coördineren, hetgeen werwijs naar de rol van metacognitie (Mayer, 1995; 1996).

De integratie van de nicuwe kennis word gestimuleerd door te elaboreren, bijvoorbeld door middel van het construeren van verklaringen. Vooral wanneer deze verklaringen zelf gegenereerd worden en met behulp van interactic in een grocp. (Chi, Bassok, Lewis, Reimann, \& Glaser, 1989; Malyer, 1996; Pressley, Wood, Woloshyn, Martion, King, \& Menke, 1992; Webb, 1989, 1991; Webb \& Sullivan-Palincsar, 1996). De meer speciffeke cognitieve processen die hierbij een rol spelen worden geillustreerd door het onderzock van Clement (1989).

\section{Onderwijsmethoden gericht op de integratie van de voorkennis met de nieuwe of geleerde informatie}

Probleemgesruurd leren is ecn merhode die erop gericht is bij lerenden cen integratic tot stand te brengen russen de voorkennis en de nieuwe informatie. Op drie tercinen is onderzoek gedaan naar de effectiviteir van onderwijsmethoden die verwantschap vertonen met probleengestuurd leren. Allereerst is dat het onderzoek naar de invloed van pre-instructionele strategieèn op het leren en onchouden van studiereksten. Een rwede terrein is het onderzoek nar coöperatief leren. Tenslorte is er vecl onderaok gedaan dat gericht is op het verbeteren van het onderwijs in de natumwetenschappen (science cducation). In dit gedeelte zal een owerzicht worden gegeven van deze onderzocken mer als doel na te gaan welke methoden er zijn en wat de effecten hicrvan zijn op het leren.

Pre-instructionele elaboratie-strategieën

Op her terrein van her leren van nicuwe informatie uit studicteksten zijn verschillende vormen van onderwijsacriviteiten onrwikkeld en voorgesteld die rot doel hebben de student als het ware te "prepareren" op de nieuw te verwerken informatic en hem of hatr aan te zetten tot het leggen wan een relatie tussen voorkennis en de nieuwe te leren informatie. Voorbeelen zijn her gebruilk van "advance organi- 
zers", gestructureerde overzichten, outlines, leerdoelen en vragen vooraf. Deze zijn er alle op gericht het leren van een daaropvolgende studietekst te vergenakkelijken (Alvermann \& Moore, 1991; Pressley \& Afflerbach, 1995; Tieney \& Cunningham, 1984). Tienney en Cunningham concluderen dat er, in regenstelling tot deze leerkracht-geinicieerde en tekstgebaseerde acriviteiten, slechts weinig onderzoek is gedaan naar door de student zelfgegenereede vormen van acriviteiren en naar activiteiten die interactie tussen studenten vereisen.

Onderzoek naar de effecter van zelfgegenereerde verklaringen voorafgande an het leren van nieuwe informatie laat zien dat dir her leren van de nicuwe informatie bevordert (Pressley er al., 1992). In veel studies nar de effecten van gegeven vragen voorafgaande aan het bestuderen van cen tekst, wordr nier wan de proefpersonen gevrangd dar ze zelf een woorlopig antwoord op die vragen bedenken woordar zij de reksr besuderen. Dit is volgens Pressley et al. (1992) een belangriik gemis, want het geven van antwoorden op vragen kan erroe leiden dat de nieuwe informatie beter wordt geleerd. In één onderzock (Pressley. Tanenbaum, McDaniel, \& Wood, 1990) werden de effecten nagegan van vragen voorafgaande aan het bestuderen van de tekst. Alle proefpersonen bestudeerden dezelfde studietekst. Een eerste groep bestudeerde alleen de tekst. Een tweede groep kreeg alleen vagen voorafgaande aan de tekst. Een derde groep kreeg vragen en werd tevens gevragd antwoorden voor deze vragen te genereren. Alle drie groepen mak kten een roers na de bestudering van de tekst. Uit de resultaten van dit onderzoek bleek dar de groep die vragen kreeg en antwoorden op deze vragen moest geven in vergelijking tot de andere twee groepen de grootste leerwinst behaalde. In verschillende andere onderzoeken werd dir effecr bevestigd.

Het onderzoek van Pressley et al. (1990) ondersteunt de veronderstelling van de effectiviteit van het zelf genereren van verklaringen op basis van vragen. Problecmanalyse in de kleine groep hecfechter als startpunt een probleem. Het onderzoek van Alvermann en Hague (1989) laar zien dar ook in dir geval zelfgegenercerde verklaringen woorafgande aan de re leren rekst het leren wan deze tekst bevordert. Alvermann en Hague (1989) gebruikten cen individuele problecmanalyse al preinstructionele strategie. Zij makten darbij gebruik van ecen problecm dar veel in het misconceprie-onderzock gebruikt wordt en warvoor de studenten verklaringen moesten genereren. Zij gingen vervolgens na wat het effect was van dric verschillende experimentele condities op het leren en begrijpen van een problemrelevante studietckst. De drie condities waren: 1. Verklaringen genereren; 2. Genereren van verklaringen plus instructic gericht op bewustwording van mogelijk misconcepties in de verklaringen; 3 . Verklaringen genereren maar nu voor een niet relevant probleem. Uir de resulaten van dit onderzock bleck dat probleemanalyse-plus-bewustwording beter werkte dan problecmanalyse alleen.

Een kenmerk wan probleemanalyse in de groep is verder dat her genereron van verklaringen niet een individuele bezigheid is maar platsvindt in interactic met 
grocpsleden. Een vorm van problemanalyse in de groep is her PREP. Dir staat woor "PrelR Fading l'lan". PREP bestaat uir ecn drierrapsprocedure (Langer. 1981; 1984\%. Voorafgaand aan deze procedure, selecteert de docent cen kernwoord, zin of beeld uit de te bestuderen rekst. Daarna komr de eerste fase, warin leerlingen "brainstormen" over dit kernwoord, deze zin of dat becld. In de rweede fase vinden er vervolgens reflecties plats over de initiele associaries. De derde fase bestaat uit een herformulering van de geacriveerde kennis. Deze fase geef de mogelijkheid aan studenten de inivële associaries die zijn geélaboreerd of veranderd door de discussic re vertbaliseren. Daarna bestudeert men de tekst. Deze PREP-procedure vind vedal plaats in groepen van tien studenten. De functic van deze activitcien voorafgaande aan her bestuderen van dle tekst is voor de docent te identificeren wat studenten teeds weten (Langer, 1981) en voor de student voorkennis re activeren en erop te claboreren (Langer, 1984). Uit de resulaten van ecn onderzoek naar de effecten van PReP'op her begrijpen van teks (Langer 1984 ) bleek dar PREP vooral cen posirief effect had op het leren door gemiddeld presterende studenten en in mincicre mate bij goed presterende studenten, terwijl de laag presrerende studenten geen positieve invloed onderwonden van PREP.

Het onderzock naar de effecten van pre-instructionele onderwijsprocedures die verwant zijn alan probleemgestuurd leren lat zien dar deze procedures een posirief Affecr hebben op her leren van nieuwe informatie.

\section{Coöperatieve onderwijsmethoden}

Coöperatieve onderwijsmethoden hebben op verschillende onderwijsniveaus een hoge vluch genomen en zijn er in vele vormen athankelijk van taakstructur, beloningsstructum, groote van de groep. etc. (Dansereau, 1988; Johnson \& Johnson, 1989; Kanselaar, Van der Linden, \& Erkens, 1997; Lamberigts, Verhagen, Gerris, \& Campbell, 1986; Slavin, 1990). Her onderzoek naar de leereffecten van coöperaticfleren is echter niet all tijd even eenduidig en levert nogal eens tegenstrijdige resulaten op (Slavin, 1991; Van der Linden, 1987; Vedder, 1985; Webb \& Sullivan-Palincsar, 1996). Een belangrijke cognitieve verklaring voor de ffecten van coöperatief leren is de cognitieve elaboratiebenadering (O'Donnell \& O'Kel1y. 1994: Slavin, 1990, 1991: Webb \& Sullivan-Palincsar. 1996). Coüperatiefleren geraen wanuit her cognicicf claboratie perspectief richt zich op de cognirieve processen tijdens de interactic in de groep. Webb $(1989), 1991)$ heef een overzich gegeven van de resulfaren van onderzoek naar de soorten interactic die een positieve reditie hebben met lecrprestaties. Uit dit overzicht bleck dat her geven van gedaborecrde verklaringen positiof correlecte met leerprestatics. Het generen van verklaringen stimulcert volgens Webb cen aantal cognitieve processen die anders nict zonden hebben platasgevonden.

Eun taik in de context van coöperarief leren dic sterk overeenkomt mer probleemanalyse wordt gebruikt in onderzock naar "brainstormen" en groepscreativiteit 
(McGrah, 1984). Brainstomen is en grocpspoces voor het op basis van en problem, genereren en evalueren van crareve ideen. Fen voorbeeld van een vak gehanteerd probleem is her "toerisrenprobleem". De rakk herbij is om maw nieren te bedenken om het antal rocristen dat de Verenigde Staten bezoek te vergroten. Deelnemers worden gesrimuleed om niet onniddellik ellarars of hun cigen ideen re bekritiseren; dar wontr in een lares sadium gedan. Ze worden wel angemoedigd, om voort te bowwen op ideen die al zinn voorgesteld (Osborn, 1957). Brainstormen kan zowel door individuen als door groepen worden gedan. Er is veel onderzoek gedan nar de effecen van deze brainscormedmiok (zic woor ovezichen van onderzock: Dich \& Strocbe 1987; Hill, 1981: Lamm \& Trommsdont, 1973; McGrath, 1984; Mullen, Johnson, \& Salas, 1991: Srroebe \& Diehl, 1994). In dergelijke onderzoeken is nagegan of branstomen werkelijk werkt, dat wil zeggen of de profpersonen kwantitatefen kwalitarief berere presta ties leverden in de groep dan wanneer zij dat alleen doen. Afhankelijke variabelen daarbij zijn onder andere rocale kwaliceit, gemiddelde kwaluteit, antal "goede" ideeën. wniekheid en verscheidenheid an ideeen. Uit deze onderzoeksresultaten concludeert McGrath: "........, the evidence speaks loud and clear: lndividuals working separarely generane more, and more creatve (as rared by judges) ideas than do groups, even when the redundancies anong nember ideas are deleced. and of course, without the stimularion of hearing and piggybacking on the idcas of others. The difference is large, robust and general." (McGrath, 1984, p. 131). Dir resulaar heef geleid tor theorievorming over en onderoek naar de oorzaken hiervan en her heefr geleid ror onderzock naar middelen en methoden voor het verbeteren van de productiviteit bij brainstormen in de groep.

Een belangrijk punt bij de interpretatie van de onderzoekingen naar de relatieve effectiviteit van individued versus groepsbrainstomen is dat men een groepsproduce heefr vergeleken mer de gemiddelde prestaties van individuen. Er kan echter een duidelijke invloed van de groep rijn op de individuele groepsleden, die nier in het gropepsoduct tor wing komt. Meer recent is ondorock gedan natr rans fer wan de groep naar het individu. (abbere, Johnson an Johnson (19)86) licen zien dar op branstormtaken duidelijke transfer van groep natandividu optrad. Op prestarienecsen deden de groepsteden her juist beter dan profpersonen die individued de brainstom taken hadden witgevoerd en darna de toets doder. In her onderzock nar de relatieve effecrivicit van individued versus grocpsbramstormen is echer nog niet nagegan wat de effecten wan dege acriviteiten zijn op het leren van nicuwe informatic.

Methoden ontwikkeld in het kader van onderwijs in de natuurwetenschappen Uit her onderack nat misconcepties in de naruurwetenschappen is gelpleken dar de aard wan de wookennis een belemmering kan aijn bij het leren van nicuwe informarie. Tevens bleek dat ondanks onderwijs op desbetreffend gebiad deac 
misconcepties bleven bestaan. Er is blijkbaar wakk sprake van onvoldoende integratie tussen de voorkennis en de nieuw te leren informatie als het gaat om her begrijpen van moeilijke natuurwetenschappelijke concepten. Deze beide zaken hebben ertoe geleid dat men is gaan zoeken naar onderwijsmethoden speciaal gericht op her voorkómen en veranderen van misconcepties (Driver, Guesne, \& Tiberghien, 1985; Sandowal, 1995). Deze nicuwe onderwijsmethoden vertonen alle sterke overeenkomsten met de uitgangspunten van probleemgestuurd leren. Zo wordt bijwoorbeeld in deze onderwijsmethoden her belang van discussie en interacrie in de groep benadrukt voor het veranderen van misconcepties.

Een voorbedd van een dergelijke merhode is die van Champagne, Gunstone en Klopfer (1985). De onderwijsstrategie "confrontatie van ideeên" gebruikt verbale interactie om conceptuele werandering te bewerkstelligen. Voordat onderwijs plaatsvindt (bijvoorbeeld in de vorm van demonstraties, oefeningen in laboratoria of her bestuderen van een studietekst) is er een fase waarin studenten een probleem analyseren. Een voorbeeld van een te verklaren probleem is de beweging van een ballon, waaruit de lucht ontsnapt. Met dit verschijnsel wordr Newtons derde wet geillustreerd. Ook andere problemen zijn vaak op kwalitatieve wijze geherformuleerde voorbeelden uit leerboeken. Nadat het probleem is gepresenteerd aan de $k_{\text {kas }}$ analyseert elke student (hardop of door her op te schrijven) de begrippen, proposities en variabelen die relevant zijn voor de sicuatie. Nadat elke student de situatic heeft geanalyseerd, vindt er een discussic plaats warin individuele studenten hun analyse van de situatie presenteren. Deze individuele analyses worden aangevuld, uitgewerkr of veranderd door andere studenten. Maar wat belangrijker is in de discussic ontstatan ook controverses. Door deze controverses worden de begrippen beter gedefinieerd en de onderliggende assumpries geexpliciteerd. Het uiteindelijke resultaat van dit alles is dat elke student expliciet bewust wordt wan zijn of haar begrip van het probleem. Na deze fase begint her onderwijs en de confrontatie van de eigen ideeën met de juiste verklaring van het problem. (Champagne et all., 1985; Champagne, Klop fer, \& Gunstone 1982)

Onderzockers naar de effectiviteit van deze interventiestrategieèn voor het veranderen van misconcepties gebruiken meestal een combinatie van onderwijsmethoden (bijv discussic, observatie, cxperimenten, colleges, analogieën) en meten hun gezamenlijkc invloed op de lectprestaties van lerenden. Zelden worden de effecten van enkelvoudige interventies gemeten, afgezet tegen een controle groep. Guzzerti, Snyder, Glass en Savas (1993) condudeerden op basis van een meta-analyse van 47 onderzocken dat de effecten van enkelvoudige interventies daardoor nier geïsoleed kunnen worden. Informatie over de effectiviteit van deze onderwijsmethow den is dan ook niet beschikbaar. Op basis van hun meta-analyse condudeerden Guzzeti et al. (1993) echrer wel dar dic onderwijsbenaderingen (combinatie van onderwijsmethoden) die cognitief conflict bij lerenden stimuleren de sterkste effecten hebben op de leerprestaties. 


\section{Probleemanalyse en de elaboratie theorie}

De theorie met betrelking tot probleemgestuurd leren (Schmidr, 1993) veronderstele dar zelfgegenereerde elaboraties, in de worm van her construeren van verklaringen voor een probleem in een groep voorafgaande aan het leren van nicuwe informatie, her leren van deze nieuwe probleenrelevante informatie bevordert. Deze theorievorming kan ondersteund worden door na te gaan war de heorievorming is wat betreft de effecten van elaboraties in het algemeen, de effecren van zelfgegenereerde elaboraties versus gegeven elaboraties en de effecten van individuele elaboraties versus elaboraties in growepverband. Tevens wordr deze theorievorming onderbouwd door na te gaan wac de empirische ondersteuning is van effecten van probleemanalyse en verwante vormen daarvan. Tenslotte zal worden nagegaan waar leemtes in de theorievorming over probleemgestuurd leren aanwezig zijn en welke empirische ondersteuning nodig is.

In de liceratuur (Alba \& Hasher, 1983, Hamilon, 1989; Kintsch; 1994; Mayer, 1996; Prawat, 1989; Pressley \& Afferbach, 1995; Schmidr, 1993) zijn, zoals gezegd, verschillende redenen te vinden voor de positreve effecten van claboratie. Hamilton $(1989$, p. 2) vat deze als volgt samen: "Elaborations may increase the redundancy of stored information, impose an organizational scheme on stored information, increase the number of contexual elements that will overlap between the encoding context and the retrieval context and/or increase the distincriveness of stored information". Naast een betere organisatie van de kennis als voorwatrde voor de roegankelijkheid en bruikbaarheid van de kennis wordt ook gewezen op her belang van bewustwording van woorkennis voor de toegankelijkheid en bruikbaarheid van die kennis (Levin, 1988; Prawat, 1989; Pressley \& Afflerbach, 1995). Met andere woorden, de theorie over elaboratie veronderstelt dat door her genereren van verklaringen er cen betere organisatie en bewustwording van deze nieuwe kennis ontstat, wardoor deze kennis berer toegankelijk en bruikbaar is. Zelfgegenereerde elaboraties bevorderen her leren meer dan elaboraties geleverd door docent, tekstboek of andere externe bronnen (Hamilion, 1989; King, 1992; Reder, 1985; Reder, Chancy \& Morgan, 1986; Wong, 1993). Hamilton (1989) concludeerde op basis van cen overziche van onderzoek op dir gebied: "In summary, learner-generated elaborations have produced more robust, consistently positive effects on the retention of verbal information than author-gencrated claborations" (p. 206). Er wordt verondersteld dat zulke gepersonaliseerde claboratice beter te herinneren ziin voor de lerende ondat zij meer consistent zijn met de ervaring en kennisbasis van de lerende (King, 1992; Levine, 1988). Zelfgegenereerde elaboraties in vergelijking met docent of tekstbock geleverde elaboratios worden verondersteld meer relaties te leggen met de voorkennis, watardoor er meer en sterkere aanknopingspunten zijn voor het zich herinneren van de informate (King, 1992). Een andere verklaring voor de grotere effectiviteit van welfgegenercerde ela- 
boraties is dat deze meer bewust worden ervaren en grotere cognirieve inspanning vereisen, dan elaboraties die door docenten worden geleverd (Pressley er al., 1992). Tenslotre bestat de mogelijkheid dat persoonlijke elaboratics moriverender (intrinsieke motivarie) zijn dan door docenten angeboden elaboraties (King, 1992).

Elaboraries die in de groep worden gegenereerd, worden verondersteld effectiever te zijn dan individueel gegenereerde elaboraties. Empirische ondersteuning woor deze veronderstelling is volgens King (1992) te vinden in her peer cutoring onderzoek en in onderzock nar coöperatief leren (Webb, 1989). Uit dit onderzoek blijkt dar her geven van werklaringen in de groep posirieve effecten heeft op de leerprestaties van studenten (King, 1992; Pressley, et al., 1992; Webb, 1989). Leerlingen blijken meer te leren wanneer zij eikaar iets uirleggen. Zo kan her geven van verklaringen in de groep de lerende stimuleren tot: verheldering of reorganisarie won kemnis op nicuwe manieren, bewustwording van leemres in kennis, herkennen en oplossen van inconsistenties in kennis, ontwikkelen van nieuwe perspecrieven en genereren wan mecr geèlaboreerde verklaringen dan wanneer de lerende de informanie alleen leert (Webb. Troper \& Fall, 1995). Verbaliseren van kennis in inreracrie met anderen heeft volgens Prawat (1989) een grotere bewustwording van die kennis tot gevolg. Pressley et al. (1992) veronderstellen dat wanneer studenten werklaringen geven aan anderen dit meer eisen suel. aan de lerende. Empirische ondersteuning voor deze elaboracie theoric over de effecten van zelfgegenereerde verklaringen in de groep voorafgaande aan de te leren srudierekst is te vinden in onderzock hoe men leert van teksten, in onderzoek maar coöperatief leren en in misconcepric-onderzoek. Taakvormen die verwant zijn aan probleemanalyse in de groep zijn in deze drie onderzoeksstromen te vinden. Hoewel er een grore variatic is in onderzockstesigns, ondersteunen deze onderzoeken de elaboratictheorie.

De directe empirische ondersteuning voor de theoric over problecmgestuund leren is beperk en rich zich alleen op de directe effecten van probleemanalyse op het leren van nicuwe informatic. Schmidr (1982) heef bijvoorbecld in verschillende $x$ perimenten de effecter van problemanalyse in de groep op her leren van een sudictckst onderzocht en rapporteert positieve effecten. In twee experimenten werd onderzocht wat de effecten van probleemanalyse waren op het leren en zich herinneren van cen studietckst. Het bloedcelprobleem dat in het begin van dit hoofdsruk is beschreven werd daarbijgebruikt. Proefpersonen waren eerstejaars studenton alan $\mathrm{HBO}$-inswellingen. Probleemanalyse in de kleine groep werd vergeleken met en controle groep dic het probleen niet analyseedde maar wel dezalfde tekst las. Vit de resultaten van de rwee experimenten bleek dat de probleemanalyse grocp signilicant hoger scoorde op en tranfertoers dan de controle groep. Tewens scoorden xij significant hoger op een herkenningstest. De problecmanalysegroep reproduceerde daumatst significant meer correcte proposities uit de rekst dan de 
controlegroep. Het antal geproduceerde inferenties verschilde echter niet significant tussen beide groepen. Schmidr concludeerde dat probleemanalyse in de kleine groep een algemeen faciliarief effect heef op her leren van cen problecmrelevante studieteksr.

De theorievorming over en de empirische ondersteuning van de effecten van probleemanalyse voor her leren van nieuwe informatie zijn beperkt en moeten verder uirgewerk worden. Zo is bijvoorbeeld onduidelijk of de gevonden effecten van probleemanalyse generaliseerbaar zijn. Meer onderzock is nodig naar de voorwarden waaronder probleemanalyse positieve ffecten op het leren van nieuwe informatie veroorzaakt. Verder worden bepalde cognirieve processen tijdens probleemanalyse verondersteld die de gevonden positieve effecten verklaren. Over de aard van deze cognitieve processen (elaboraties) is echter weinig bekend. Vooral wat berreft de relarie tussen de interactic in de groep en deze cognitieve processen. Daarbij komt dat ook de merhodologie voor dergelijk onderzoek nog onvoldoende voorhanden is. Kortom ook op dit gebied is er meer onderzock nodig. Het onderzock waarover in dit procfschrift verslig word gedaan richt zich op deze onderwerpen. 



\section{Differentiële effecten van probleemanalyse in de kleine groep op het verwerken van tekst bij beginners en gevorderden'}

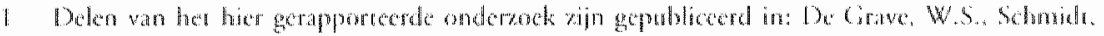

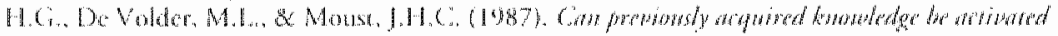

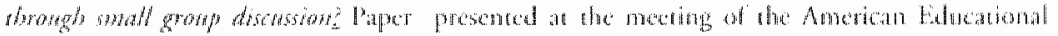

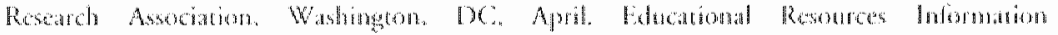

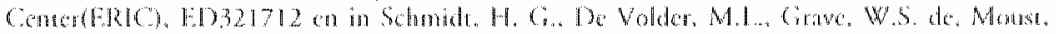

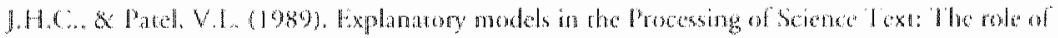

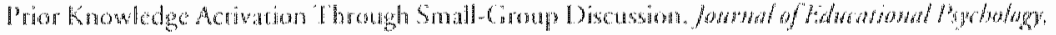
$89(4), 610019$ 


\section{Inleiding}

En belangrijk uitgangspunt van de cognirieve psychologie is de veronderstelling dar het begrijpen van een tekst een actief en constructef proces is. Begrijpen van cen tekst implicecrt dat de nicuwe kennis geintegreerd moet worden met het reeds bestaande kennisbestand. Het begrijpen van wetenschappelijke teksren berekent her bouwen van een mentaal model van her systeem of proces dat in de tekst worde beschreven (Mayer, 1996; Kintsch, 1994). Een belangrijk kenmerk wan informatie die geintegreerd is in de reeds anwezige kennis is dat deze kennis gemakkelijk te herinneren en re gebruiken is. Nier geintegreerde kennis daarentegen is moeilijker roegankelijk en moeilijker te gebruiken.

Problecmanalyse in de groep, zoals in Hoofdsruk 1 beschreven, is een onderwijsprocedure die erop gericht is on de integratie te vergroten tussen de reeds aanwerige kennis en de nieuwe, nog te leren informatie. Kort samengevat wordt verondersteld dat problecmanalyse relevante voorkennis acriveert en daardoor de leerlingen in staat stelt om, op een bepaald niveau van begrip. mer het probleem on te gaan. De tak is het vinden van verklaringen voor de verschijnselen in termen van cen onderliggend proces. Dekennis die wordt geacriveerd door de analyse van her problecm zal de vorm hebben van een probleemspecifek verklaringsmodel op basis van de kenmerken van de tak. Eir wordt verondersteld dat dit model, geconstrucerd voor het begrijpen van her probleem, het begrijpen van nicuwe informatic over dat probleen zal vergemakkelijken.

Mayer (1989a; 1996) noemt als voorwarde voor deze onderwijsmanipulatie dat deze a, de anndache van de lezer moer richten op de verklarende informatie in de rekst; b. deze informarie moer organiseren: en c. de lezer moet helpen deze re integreren. Schmide (1982) heefr in een onderzock aangetoond dat problecmanalyse inderdad leide tot het activeren wan voorkennis en het ontwikkelen van werklaringen stimuleert. Dit onderzock last echter niet zien of en in hoeverre er werkelijk cen integratic op gang komt wssien de geactivecrde vookennis en de nieuw re leren informatic.

Uir ecn overzich watn onderzock natronderwigwariabelen die de integratie van de nicuwe informatic in de bestande kennis bevorderen (Prawar. 1989) blijk dat ecn wwectal factoron van invloed zijn op de integratio en daarmee de roegankelijkheid van de kennis, namelijk de orgathisatie wan de kennis en bewustzijn van die kemnis. Onderwijsvariabelen die volgens Prawat vin invloed rijn op de organisatie van kenus zijn: $\mathbb{l}$. het on wikkelen van diverse wormen van representatie voor de re leren informatic, zoals analogicen, conceptuele modelen, meraforen; 2 . her explicier maken van hoe belangrifke elenenten van de intormatie aan elkaar gerelateerd ziju: on 3. het expliciteren cn activeren van de waïeve en informele kennis van studenten. In het onderzoek naw het leren wan wetenschappelijke studiereksten heef Mayer (1987; 1989a: 1989b) empirische ondersteuning gevonden voor deze 
onderwijsvariabelen. Vooral voor dic onderwijsvariabelen die studenten stimuleren tot het zelf genereren van elaboraties (Mayer, 1987). Bij probleemanalyse wordt werondersteld dar studenten zelf conceptuele modellen, analogieèn en metaforen genereren, zoals reeds in Hoofdsruk 1 is geconsrateerd. Doordar in de probleemanalyse verder door studenten meerdere verklaringen gegenereerd worden met verschillende concepten kunnen ook de relaties tussen deze concepten explicierer worden voor de studenten. Tenslotte wordt verondersteld dat probleemanalyse het activeren van de voorkennis scimuleen trie her voorbeeld van het bloedceprobleem in Hoofdstuk 1).

De toegankelijkheid en integratie van de nieuwe kennis, zo stelt Prawar (1989), worde verder gestimuleerd wanneer studenten meer bewust worden gemaakt van war ze weten en wat ze nier weren over een onderwerp. Verschillende onderwijsvariabelen die dir bewustzijn beinvloeden zijn: 1. her verbaliseren van kennis en 2 . discussie over kennis. In een overzicht van onderzoek naar leeromgevingen waarin interactie in de kleme groep centraal staat concludeerden Brown en Palincsar (1986, p. 395):

"Dat integratie van kennis waarschijnlijker wordt wanneer de student zijn of haar standpunt moet verklaren, uitleggen of verdedigen ten opzichte van die van anderen. De noodzak om te verklaren is daardoor vaak de stimulans om hem/haar ertoe te zetten eigen kennis te evalueren en te elaboreren"

In de fase van probleemanalyse moet de student, wanneer deze verk laringen genereert, de beschilkbare kennis werwoorden en door de confrontatie met alternarieve verklaringen wordt de student bewust gemalkt wan de grenzen van de voorkennis en van mogelijke discrepanties tussen wat begrepen wordt en nog moet worden begrepen. Probleemanalyse in een kleine groep kan, op basis van bovenstaande factoren, geacht worden van invloed te zijn op de integratie van de nieuwe informatie in het oude kennisbestand.

In een overzicht van onderzock naar de effecten van onderwijsmerhoden gericht op integratie van de nicuwe in formarie in de bestaande kennis constatecrde Mayer $(1987 ; 1989 \mathrm{a} ; 19896)$ dat er bepaalde leereffecton te verwachten zijn. Deze effecren hebben niet alleen betrekking op de kwantitatieve aspecten, matr ook op de kwalitatieve aspecten van leren. Wanneer een werenshappelijke studictekst geleerd wordt en men zich deze moet herinneren verwacht Mayer dar studenten meer de verklarende dan de beschrijwende informatie uit de tekst zullen herinneren. Mayer legt de nadruk op dir patroon wan lecrprestaties, ondat wanneer men alleen kijkt naar de hoeveetheid recall, men volgens Mayer vaak geen duidelijke verschillen vindt tussen experimentele en controle groepen. In verschillende overzichen van onderzock naar de effecten van elaboratie aktiviteiten van lerenden op her onthouden van informatie uit de tekst is empirische onderstcuning voor dese veronderstelling ontrent leereffecten gevonden (Mayer. 1987; 198\%a). 
Er kan een onderscheid gemakter worden in verklatende en descriprieve proposiries die een lerende zich therinmert van en studierekst. Volgens Mayer (1985a, $1985 b$ ) is ther aantal verklarende proposities in free recall een gevoelige meting voor de diepte van integratie van leerstof in bestaande kennisstrukturen. Bromage cn Mayer (1981) bijvoorbeeld ontdekren een correlatie van .59 tussen het aantal verklarende proposiries in de recall wan een tekst en gedrag op een test woor problemoplossen war proefpersonen de kennis moesten toepassen die werkregen was uir de tekst. Ze suggereren dat de betere probleemoplossers een representarie wan de informatic hadden geconstrucerd die beter geintegreerd was in hun voorkennis. Het onderscheid tussen verklaring en descriptie likt relewant ondat probleemanalyse ook gericht is op het produceren van verklaringen. Daarbij komt dat her beschouwd werd als een goed alternatief voor het aantal inferencies op grond van cle bestudeerde tékst als een (meer algemeen gebruikte) meting van integratie (Van Dijk \& Kintsch, 1984). Toegepast op de onderwijsvariabele probleemanalyse is de voorspelling dat probleemanalyse zall leiden tor een verbeterde recall van de meer belangrijke informatic in een daana te bestuderen tekst. De veronderstelling hierbij is dat problemanalyse de studenten helpt de aandacht te richten op de verklarende informatio in de tekst, deze informatie te organiseren en te integreten in de bestande kennis.

In de cognicieve psychologie is geconstateerd dar leerprocessen kunnen verschillen bij lerenden mer minder of met meer kennis en dat er fasen in her leerproces te onderscheiden zijn (Shuell, 1986). Dit kan leiden rot differentiële effecten van onderwijmerhoden bij de verschillende fasen in het leren. Volgens Shuell (1986, p 429) kunnen "... given (educational) variables may facilitate acquisicion during one phase of learning and have litele, if any, effect during other phases". In de literatuur vind men verschillende hyporhesen over de differentiole effecten van onderwijsprocedures bij studenten mer verschillende voorkennis. Mayer (1989a; 1989 ) veronderstelt dat onderwijsmethoden, die gericht zijn op integrarie wan nicuwe informatie in de reeds anuwerige kenn is, her meest effecticf zijn bij studenren die niet spontann in zinvolte leerprocessen zouden dectnemen. Een beginnerleerling bijwoorbeeld bezit nog nier of kan nier gemakkelijk een mentaal model wan de te leren informatie genereren. As onderbouwing wan deze tedenering verwijst Mayer nat het onderzock naar de effecriviteit van onderwijsmethoden bij individucle lectingen (Snow \& Lohman, 1984). In dir onderzoek werd geconstateerd dat onderwijsmethoden gericht op de integratie van leerstof her meest succesvol zijn bij minder vaardige studenten en bij studenten met weinig voorkennis. Deze hypothese zou betekenen dat probleemanalyse bij beginners duidelijker effecten zou hebben dan bij gevorderden.

Deze hypothese wordt ondersteund door de theorie dat wanneer men studenten bewust makk van de beperkingen en grenzen wan de voorkennis voorafgaand aan het begrijpen van nieuwe informatie dit een positief effect heeft op her leren van 
deze informatie (Champagne, Klopfer, \& Gunsrone, 1982; Prawat, 1989). Anderson (1977) verwoorde her als volgt: "My conjecture is that the likelyhood of schema change is maximized when a person recognizes a difficulty in his current position and comes to see that the diffculty can be handled within a different schema" (p. 427). Omdat de kennis wan beginners in verschillende opzichen geringer is in vergelijking tor de kennis wan gevorderde srudenten, kunnen zij duidelijker discrepanties ervaren tussen hun huidige kenmisstand en de kenuis die nodig is om het probleem werkelipli te begrijpen. Probleemanalyse woorafgand aan het leren van een rekst kan daarom bij beginners de grootsce invloed hebben.

In dit experiment werden de effecten van probleemanalyse op het leren van een daaropvolgende studiecekst onderzocht. De proefpersonen analyseerden en relewant probleem of cen irrelevant probleem voorafgande tan het bestuderen wan een tekst over osmose om de mogelijke differenriële effecten van mate van woorkennis op het zich herinneren wan de rekst te onderzoken. Zowel proefpersonen mer weing voorkennis (beginners) en proefpersonen mer meer kennis (gevorderden) namen deel aan dir experiment. De belangrijkste athankelijke variabele in de volgende analyses is het onderscheid tussen verklarende en descriptieve proposities in free recall.

\section{Methode}

Proefpersonen

Proefpersonen waren 88 leerlingen wit een school voor voortgezer onderwijs (VWO): 46 derde jaars leerlingen (18 jongens en 28 meisjes) en 42 vierdejaars leerlingen (24 jongens en 18 meisjes). De leeftijd van de derdejaars was gemiddeld 16,91 jaar (met een standaard deviatie van 0,59 ) en die wan de vierdejaars was gemiddeld 16,41 jaar (standaard deviatie 0,52).

De derdejars leerlingen waren onbekend met het biologienderwerp Osmose. Ze hadden echer wal algemene biologiekennis, daabij inbegrepen globale kennis wan de surucuur van cellen. Als gevolg darvan werden zij beschouwd als beginnets. De vierdejars proefpersonen hadden recent het onderwerp osmose afsloten als onderdeel van hun biologieonderwijs, zij waren de gevorderden in dir experiment. De proffersonen werden at random toegeween an de verschillende groepen in her experiment, wardoor vier groepen werden gecreeerd: experimentele en conrrole groepen voor zowel beginners als gevorderden.

\section{Materialen}

De materialen bestonden uit twee problecmbeschrijuingen, een tekst, cen free recall toets en ecn aanvulroers. De problembeschrijwing woor de experinentelecondicie besrond uir de beschrijving van een rode blowded in verschillende omstandigheden: "Een rode bloedcel is geplatst in zuiver warer onder een microscoop. De 
bloedcel zwelt snel en barst uireindelijk. Een andere rode bloedcel wordt toegewoegd aan een oplossing van zout in water en deze schrompelt ineen". De leerlingen worden gevraagd om deze verschijnselen re verklaren in termen van onderliggende processen, principes of mechanismen. De probleembeschrijuing voor de controle groep was als volgr geformuleerd: "Op de Amsterdamse Luchthaven kan men waarnemen hoe vliegtuigen die verschillende tonnen wegen, blijkbaar zonder moeite de lucht ingaan. Hoe kan dit verschijnsel worden verklaard?"

De tekst was een zespagina dik boekje mer in totaal 2.220 woorden (zie Appendix 1). Her was geticeld "Osmose en diffusie" en bevatre passages over diffusie, diffusiesnelheid, doorlarbaarheid van celmembranen, osmose, osmotische druk, osmotische waarde, de celstructuur van planten, turgor en plasmolyse. In de tekst werd niet verwezen naar osmose in bloedcellen. De free recall toets bestond wit drie witte pagina's en cen voorpagina mer de volgende instructic: "Schriff alles op wat je herimert van de tekst over osmose en diffusie. Schrigf in volle zinnen en vermijd cen telegramstipl of tekeningen."

Voor her vaststellen van wat men zich herinnerde wan de tekst werd gebruik gemakkt van een op basis van de tekst en tekststructuur geconstrueerde aanvulroets met in rotal 55 vragen. De aanvul coets is geconsrueerd op basis van een analyse van de rekst over Osmose en diffusie. Met behulp van een geconstrueerde tekststructuur (zie Schmidr, 1982) werden wragen voor de aanvultoets gemaakt die representatief waren voor de tekststructuur (de verschillende niveaus van de teks:structuur waren in de anvultoets vertegenwoordigd). In de roets komen verschillende ypen vragen voor zoals vragen naar definities, vragen naar voobeelden, vragen naar verbanden tussen begrippen en verschijnselen. De bewoordingen van de vragen sloten zo letterlijk mogelijk aan bij die van de tekst over osmose en diffusie. De betrouwbarheid (interne consistentie) van de anvultoets is $\alpha=0,87$.

\section{Procedure}

De proefpersonen (gevorderden en beginners) werden at random toegewezen aan en experimentele $(\mathrm{n}=43)$ of een controle conditie $(n=45)$. Zowel experimentele als controlegroepen (bij beginners en gevorderden) werden vervolgens onderverdeeld in vier kleine groepen wan ongeveer gelijke groote. Alle proefpersonen waren, binnen hun conditie, willekeurig toegewezen aan groepen ter grootte van zes of zeven tecringen. De experimentele proefpersonen analyseerden het bloedcelproblcem, terwiil de controle groepen het wiegtuigprobleen analyseerden. Een proelleider werd aan elk van deze groepen toegewezen. Alle proefpersonen ontwingen geschreven instructics, warin werd uitgelegd wat van hen werd verwacht. Het voorbed anwezig in de instructie (statische elekriciteit als een verklaring voor her verschijnsel onween) was niet gerelateerd aan het onderwerp osmose. De proefleider toesste, door het stellen wan vragen, of de proefpersonen begrepen hadden hoe zii her experimentele probleem moesten aanpakken. De introductie nam 
vijf rot tien minuten in beslag. Daaropvolgend werden de proefpersonen vijtien minuten gegeven om verklaringen te formuleren woor of her bloedcel probleem of voor her placebo probleem. $\mathrm{Na}$ het lezen wan het probleem. wat ongeveer één minum duurde, begonnen de proefpersonen verklaringen te geven. De proefleider handelde als gesprekleider, en gaf regelmarig samenvarringen wan de verschillende opvattingen. De discussie werd op band opgenomen, watrdoor er geverifieend werd dat geen informatie werd gegeven waaruir proefpersonen inzichren konden afleiden van de onderliggende mechanismen van beide problemen. Drie en zevenrig procent van de bijdragen van de proefleiders bestond uit vragen nar verheldering; de overblijvende opmerkingen waten samenvartingen die dezelfide terminologie als de proefpersonen gebruikren of aanmoedigende gelluiden zoals "uh' 'huh". De proefleider was geïntrueerd om de discussie re beëindigen wanneer er geen reactie kwam op zijn wraag of iemand nog iers wilde toevoegen of verklaren.

De experimentele proefpersonen analyseerden her bloedcelprobleem, terwijl de controle groepen het vliegtuigprobleem analyseenden. De genviddelde tijd die voor de discussie werd gebruikt was 9 minuten en 10 seconden (range ongeveer $1 \mathrm{mi}$ nuut en 25 seconden). Er werclen geen systematische verschillen in discussierijd gevonden tussen beginners en gevorderden of tussen de problemen. Gemiddeld spraken de profpersonen ongeveer $82 \%$ van de tijd, met slechrs marginale verschillen russen de groepen.

De rijd om de tekst re bestuderen was 20 minuten. Verder moesten de proefpersonen nog een korte vragenlijst invullen die ten doel had om overdrachrseffecten re voorkomen. Daaropvolgend werd de free recall toets over osmose aangeboden aan zowel de experimentele als de controle groep. Er was geen tijdslimier gesteld aan de beantwoording van de free recall toets. Na de free recall toets kregen de studenten de aarvulltoets aangeboden.

\section{Analyse}

Scoring: allereerst werden de door de proefpersonen geproduceede free recall protocollen door rwee onathankelijke beoordelaars onderverdectd in onderwerp-gezegde cenheden (of proposiries), die elk en enkel idee weergeven. De overenstemming cussen de beoordelaars was $96 \%$. De grenzen cussen twee proposities kan worden gevonden door her identificeren van geschike linguistische signalen in de teksr, zoals: voegwoorden, bijwoorden, zalfstandige naamwoorden, komma's, punten en haakjes. Een voorbeeld word geleverd door her wolgende protocol (schuine strepen markeren grenzen): 
Osmose is het proces/ waardoor een grorere concentrarie water aantrekr uitt een keinere concentratie/ wanneer deze concentraties worden gescheiden door een semipermeabele membraan/ Het Griekse woord osmose betekent duw/ De aspiratie van water moleculen wordt gerealiseerd door diffusie/ (diffundere betekent verspreiden)./

Vervolgens werd elke propositie op correcheid gecontroleerd. De overeenstemming tussen beoordelaars hierbij was $88 \%$. Verder werden de proposinies gecategoriseerd als zijnde verklarend of descriptief van aard. Een verklarende propositie werd gedefineerd als een verklaring die of een proces karakteriseert, of een voorwaarde beschrijft watronder een proces platsvindt. Alle andere proposities werden beschouwd als descriptief. De volgende zin levert voorbeelden van drie verklarende proposities: "Wanneer zoutoplossingen aan verschillende kanten van een semipermeabele membraan en verschillende concentratic hebben, zullen watermoleculen zich bewegen door de membraan van de hogere naar de lagere concentrarie, trot equilibrium is hersteld." Een voorbeeld van een descriptieve propositie is: "Osmose gebeurt zowel in mensen als in planten". De overeenstemming tussen beoordelaars voor deze categorisering van proposities was $89 \%$. Meningsverschillen cussen beoordelaars werden opgelost door discussie. De gegevens van de free recall coers werden geanalyseerd door gebruk te maken van een herhalde neting variantic analyse met rwee tussen proefpersonen factoren (condirie en niveau van expertise) en een binnen profpersonen factor (de rype proposities die worden herinnerd: Verklarende versus descriprieve). De gegevens van de aanvultoers werden geanalyseerd door gebruik te maken van ANOVA.

\section{Resultaten}

\section{Free Recall}

De resultaten worr het andal correct verklarende proposiries en her anal cortec beschrijuende propositics staan vermeld in Tabel 3.1 .

De herhatue meting varianrie analyse wan de free recall gaf de volgende resultaten: Len significant verschil werd gevonden tussen de groepen bloedcelproblecm en comeroleproblecm wat berrelit de total antal cortect herinnerde proposities, $F(1$, $82)=6,15, M S^{2}=116,69, p<0,05$. Zoals kon worden verwach $\mathrm{c}$ produceerden gevorderden significine meer accurate proposities dan beginners, $F(1,82)=82.47$, $M S_{i}=116,69, p<0,001$. Het interactic effect wussen treatnent en niveau van expertise was nier significant, $F(1,82)=0,01, p<0,93$.

Uit de analyses blijke verder dar significan meer verklarende proposiries dan descripticre proposirics van de rekst werden herinnerd, $F(1,82)=179,16, M S_{\text {: }}=$ 
Tabel 3.1. Gemideld actal correcte verklaringen en correcte bescliningen herhnerd.

$$
\text { Bloedcelprobleem Controbe problem }
$$

\begin{tabular}{lrrrrrr} 
Soort propasitie & Gem & \multicolumn{1}{c}{ sd } & \multicolumn{1}{c}{$\mathrm{n}$} & Gem & 5d & 0 \\
Beginners & 26,0 & 12,4 & 22 & 18,5 & 6,6 & 22 \\
Verklaringen & 9,5 & 9,9 & & 13,7 & 6,5 & \\
Beschrijingen & 6,5 & 4,1 & & 4,8 & 11,8 & \\
Gevorderden & 53,4 & 25,7 & 21 & 48,2 & 15,6 & 21 \\
Verklaringen & 41,8 & 18,3 & & 32,5 & 11,5 & \\
Beschrijumgen & 11,6 & 7,3 & & 15,2 & 7,6 &
\end{tabular}

$65,41, p<0,001$. Interessanter dan dir hoofd effect zijn de significante interacties tussen treatment en type proposities die worden herimnerd, $\mu(1,82)=7.77, M S^{\circ}=$ $65,41, p<0,01$, en her niveau van expertise en de soort proposities die worden herinnerd, $F(1.82)=20.47, M S_{c}=65.41, p<.001$.

Het verschil russen treatment effecten is veel groter voor verklaringen dan voor beschrijwingen. Voor verklaringen was het verschil tussen condities significant, $F(1$, $82)=4,73, M S_{0}=254,93, p<0,05$; voor beschrijwingen was her verschil niet significanr, $F(1,82)=0,18, M S_{6}=54,40, p<0,67$. Deze resultaten impliceren dat het experimentele effect, zoals weerspiegeld in de reall, geheel veroorzakt werd door de verwerking en herinnering van verklarende informatie. Beschrijvende informarie uir de studierekst worde niet beter herinnerd als gevolg van de analyse van het bloedcelprobleem. Dit effect is sterker voor de gevorderden dan voor de beginners, vandaar het interactie-effect tussen niveau van expertise en her type propositie herinnert.

\section{Aanvultoets}

De resulaten voor het gemiddeld antal correct herinnerde items van do anvultoets staan vermeld in Tabel 3.2. De variantie analyse gaf de volgende resultanten: Er werd geen significant werschil gevonden tussen de groepen bloedcelproblcem en controleprobleem wat betreft de total antal correct herinnerde proposities. $F(1,82)=1.50, M S_{c}=24,90, p=0,225$. Zoals kon worden werwacht, produced den gevorderden significant meer accurate proposities dan begmers, $F(1,82)=$ 134,26, $\mathrm{MS}^{\circ}=24,90, p<0,001$. Her interactice effect ussen trearment en niveau van expertise was significant, $F(1,82)=4,83, M S_{c}=24,90, \beta<0,05$.

Zoals Tabel 3.2 laat zien is het verschil wat bereft her experimentel effect groten voor beginners dan voor gevorderden. De beginners in de groep blocdcel problem in vergelijking tor de beginners in groep controle probleem herinneren sig 
Tabel 3.2. Gemideld analail correct hermerde tems van de aanuttoets.

\begin{tabular}{lcccccc}
\multicolumn{3}{c}{ Bioedcelproblewn } & \multicolumn{3}{c}{ Controle problem } \\
& gem & sd & $n$ & gem & $5 d$ & $n$ \\
Beginmers & 26,3 & 6,1 & 22 & 22,6 & 5,6 & 22 \\
Geworderden & 36,4 & 3,9 & 21 & 37,4 & 3,9 & 21
\end{tabular}

nificant meer correcre items, $M(1,82)=4,39, M S_{\mathrm{e}}=33,99, p<0,05$. Gevorderden in de rwee verschillende groepen daarentegen werschillen nier significant van elkatar wat berreft thet aantal correct herinnerde items, $F(1,82)=0,75, M S_{\mathrm{e}}=33,99$, $p=0,39$. Deze resultaten bevesrigen de veronderstelling dar beginners meer profije hebben van probleemanalyse dan gevorderden.

\section{Discussie}

Her doel van deze studie was na te gaan wat de differentiële effecten waren van problecmanalyse in een kleine groep op het leren van een tekst bij beginners en gevorderden. De resultaten van de free recall wijzen erop dat wanneer proefpersonen her bloedcelprobleem gegeven wordt en daabij de instructic onrwangen om verklaringen voor her gedrag ervan te produceren, dit over het algemeen het verwerken en zich herinneren van een probleem relevante tekst vergemakkelijkt. Deze resultaten zijn consistent met het idee dat probleemanalyse een algemeen facilitaricve werking heef op het leren van een probleemrelevante sudietekst. Ook Schmidi (1982) vond een faciliraticve invloed van probleemanalyse op her leren van cen sudierekst. De veronderstelling dar beginners meer zouden profiteren van problemanalyse dan gevorderden is gedeeltelijk bevesrigd. Her gevonden verschil tussen de experimentele en de controle groep is groter voor de beginners dan voor de gevorderden (vooral bij de aanvultoers). Dit kom overeen mer de resultawen van ander onderzoek (Mayer, 1989b). De hyporhese, dat zij die meer voorkennis zouden hobben meer zouden leren door de activaricprocedure, worde dus niet ondersteund door de resultaten van dir experiment. De resultaten van de free recall toess haten echrer zien dat ook gevorderden profijt kunnen hebben van probeemanalyse in de kleine groep. Gevorderden en beginners schijnen allebei te worden beinvloed door probleemanalyse voorafgande aan het leren van een tekst. De gegevens omurent her parroon wan de free recall conen duidelijk aan dar wanneer proefpersonen gevragd worden een verzameling naumulijke verschijnselen te verklaren in remen van hun causale onderliggende processen, dit ertoeleidr dat de proctpersonen werklowende informatic uir een tekst oppikken die te maken heeft 
met deze verschijnselen. Problemanalyse heef blijkbaar de studenten geholpen de aandachr re richten op de verklarende informatie in de tekst en hen gestimuleerd daartussen relaties te leggen en deze te integreren in de voorkennis. Het herinneren van descriptieve feiten wordt niet specifiek ondersteund door de onderwijsprocedure. Deze resultaten zijn in overeenstemming met andere onderzoeken die her onderscheid in verklaringen en beschrijvingen in recall hebben gebruikt (zie Mayer, 1987: 1989a; 1989b).

Hoe zijn de resultaten van dit onderzoek nu te interpreteren vanuit de in Hoofdstuk 2 geformuleerde hypothesen? Tenminste drie antwoorden zijn mogelijk. De eerste is een modvationele verklaring. De proefpersonen werden geconfronteerd met een probleemsituatie waarvoor ze geen bevredigende oplossingen thadelen. Berlyne (1978, zie ook Loewenstein, 1994) suggereert dat wanneer een individu een discrepantie ervaart tussen wat hij of zij weet over een onderwerp en wat men zou moeren weten, er een cognitief-motivationed proces word opgeroepen. Dit proces, dat Berlyne de epistemische nieuwsgierigheid noemt, heeft informatiezoekend gedrag tor gevolg dar gericht is op de overbrugging van de kennisklool. Een implicarie van deze hypothese zou zijn dar de groep gevorderden, die over her algemeen geen moeite had om te verklaren waarom de bloedcel incenschrompelde of zwol, minder epistemische nieuwsgierigheid zou ervaren, en dus minder leerde dan de groep beginners. Deze voorspelling is echrer in regensprak met de resultaten van het experiment, omdar er geen interactie-effecr werd gevonden tussen treatment en niweaus van expertise bij de free recall toets. Bij de aanvultoets dararentegen werd wel een interactie-effect gevonden. Gegeven de trend bij de free recall roers en her interactie-effecr bij de aanvultoers kan de morivatie hyporhese niet uitgesloten worden. De motivationele hypothese kan echter nier duidelijk maken waarom in het bijzonder verklarende informatie beter herinnerd wordt.

Een tweede mogelijkheid is een verklaring op basis van het idee van selectieve aandacht. Omdar de proefpersonen werden gevraggd verklaringen re produceren voor het gedrag van de bloedcel, kan het zijn dat ze zich speciaal gerich thebben op de verklarende informatie in de tekst over osmose en diffusie en daarom betere recall hadden van dat soort informatic. Studies binnen het kader van de selectieve aandach hebben over het algemeen angeroond dar andacht schenken aan specificke delen van een tekst resulteert in superieure recall van die delen, maar dat gat ten koste van delen dic minder aandacht krijgen (Goctz, Schallert, Reynolds, \& Radin 1983; Mayer 1987; Rothkopf \& Ballingron, 1979). Dus hocwel deze hyporhese kan verklaren watrom de experimentele groepen superieure recall wan verklarende informatic toonden, slaagt het er nict in te verklaren waarom de reall van descriprieve informatie van de experimentele groep nier slechter was dan de recall van de controle groep als resultaar van de door eersigenoemde minder andachr geven aan die elementen van de tekst. 
De derde kandidaat voor een anwoord is de eerder besproken elaborarie hypothese. Volgens deze hypothese activeren proefpersonen rijdens de probleemanalyse voorkennis over de actuele of gerelateerde onderwerpen. Door de aard van de taak zal de geactiweerde voorkennis ertoe neigen werklarend van aard te zijn. Wanneer do rekst bestudeerd wordt, zullen de bestaande cognirieve strucruren, waarin de informarie uit de tekst moet worden geïntegreend, warschijnlijk de eerder geacriveerde verklarende kernis zijn, omdat deze meer toegankelijk is dan de niet geacriveerde descriptieve kennis. Dir zou nier alleen verklaren waarom meer informarie van de tekst wordt herinnerd, mar ook waron verklarende in formatie in her bijzonder beter wordt herinnerd. Daatbij komt dar verklarende informarie over het algemeen meer coherent is dan de descriprieve feiren, omdar de verschillende proposities causal werbonden zijn in her geheugen, hetgeen her herinneren van die proposities kan vergemakkelijken.

Een onderwerp dar niet explicier behandeld is in dit experiment is de mate warin groepsprocessen kunnen hebben bijgedragen aan leren. Webb (1989) heef bijwoorbeek aangeroond dat het geven van verklaringen in reactie op vragen zegenrijk kan zijn woor zowel de gever als de ontwanger. In het volgende experiment wordr specifick op deze vraag ingegaan. 
Hoofdstuk 4

\section{Relatieve effectiviteit van probleemanalyse in de groep vergeleken met individuele probleemanalyse en activatie van voorkennis'}

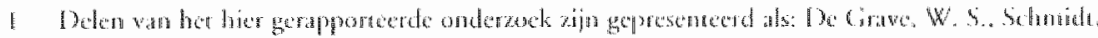

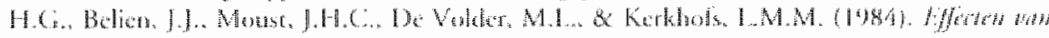

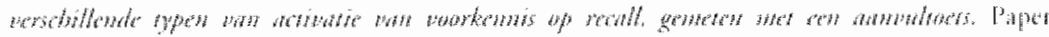
gepresenecrd op de Onderwigh Research Oagen. Milburg. 


\section{Inleiding}

In her vorig hoofdstuk is onderzocht war de relatieve effectiviteit is van probleemanalyse in de groep bij beginners en gevorderden. Als concrole groep werd daarbij gehanteerd een irrelevant probleem dat de studenten in de groep dienden te analyseren. In de opzet wan dit onderzock is er echter geen rekening gehouden met de mate waarin interactie in de groep kan hebben bijgedragen aan de leereffecten. Problemanalyse vinde plaats in een coöperatieve leersituatie, warin lerenden op elkaar a angewezen zijn en mer elkaar samenwerken. Een belangrijk kenmerk van coöperatieve leersituaties, dar deze onderscheidr van individuele leersicuaties, is de mogelijkheid van interactie russen de lerenden. Tijdens de probleemanalyse zijn er cen aantal activiteiten van de lerenden, die aangeduid kunnen worden met interacrie, zoals informatie geven, wragen stellen aan elkaar, naar elkaar luisteren, kriliek geven, etc. Tijdens deze interactie kan men van elkaar leren.

In een antal scudies is gebleken dat interactie in een leergroep een positief effect heeft op de leerprestaties wan lerenden. In een overzicht van correlationeel onderzoek naar de effecten van coöperaticve leersituaties (Webb, 1989) bleek dat bepaalde vormen wan interacrie positieve effecten hadden op de leerprestaties van scudenten. Dit onderzock heeft uitgewezen dat de correlaties russen zelf gegenereerde verklaringen en leerprestaties positief en signifikant was. Her genereren van gëlaboreerde antwoorden op vagen gesteld door medestudenten stimuleert volgens Webb (1989) een verscheidenheid aan cognirieve processen, die in individuele leersituaties niet zouden hebben platsgevonden. Deze onderzoeksresultaten zijn consistent met resultaten uir experimenteel onderzoek. Pressley, Wood, Woloshyn, Martion, King, \& Menke (1992) hebben een overzicht gegeven van experimenteel onderzoek naar de leereffecten wan het geven van verklaringen voorafgande aan de te leren tekst. Uit dit onderzoek bleek dat deze activiteit het leren van de rekst vergemakkelijkt. Deze conclusie trokken zij onder andere uir experimenteel onderzoek naar de effecren van her reageren op vragen (dus her genereren wan geëlaboreerde anrwoorden) die gesteld waren woorafgaande aan de bestudering van een tekst en door "elaborative interrogation" (het genereren wan clabotaties in reaktic op waarom-vragen voorafgande aan de te leren tekst). Dit onderzock ondersteun dus de hypothese dat het zelf konstrueren van verklaringen met name in cooperaricve concext het leren van een daropvolgende tekst vergemakkelijkr.

Onderzock naar de effecten van brainstormen in de groep (cen werwante acriviteit aan problemanalyse) versus individueel brainstomen (Diehl \& Stroebe, 1987; Mullen \& Johnson, 1991; Stroebe \& Dichl, 1994) laar daarentegen zien dat interactic niet altijd posicicve effecten heef. In dir onderzock is men vooral gericht op hee vergelijken van groepsproducren mer individuele producten, bijvoorbeeld het aantal geproduceede ideeën door de brainstorm. De resultaten van dergelijk on- 
derzoek wijzen uit dat individucel brainstormen berere resultaten oplevert dan brainstomen in de groep (Diehl \& Stroebe, 1987, MoGrath. 1984; Mullen \& Johnson, 1991; Srroebe \& Diehl, 1994). In dit geval spreekt men van procesverlies. Procesverlies gebeurt wanneer minder ideë̈n, minder oplossingen, minder inspanning voor een leertaak binnen groepen plaatsvindt dan wanneer men individueel werkr. Proceswinst vindt plaats wanneer meer nieuwe idceën, oplossingen of pogingen worden gegenereerd door groepsinteracrie dan wameer studenten alleen werken.

Een viercal verschillende verklaringen zijn er gegeven voor dit procesverlies (Brent-Gallupe, Bastianutti, \& Cooper, 1991; Stroebe \& Dichl, 1994): 1. "Social loafing" of "Free Riding", dit betekent dat leden van een groep niet zo hard werken in een groep als wanneer zij alleen werken; 2 . Het gevoel geëvalueerd te worden door de andere groepsleden; 3. "Producrie blokkering", ondar slechts één persoon regelijk kan praten kan dit een negatief effect hebben op andere groepsleden. Deze kunnen belemmerd worden in het formuleren wan ideeën, in het denken aan nieuwe ideeën en het vergeten van ideeën. Tenslorte 4. "Producrie matching", ondar de leden van de groep warschijnlijk onzeker zijn over her nuveau van individucle productiviteit dat er van hen verwacht wordt zullen deze groepsleden erroe geneigd zijn om hun eigen gedrag te vergelijken met dat van andere groepsleden. Wanneer er discrepanties zijn zal er een matching van prestaties zijn, dic naar her gemiddelde gaat. Wanneer de groepsnorm al laag is zal dit leiden rot lagere prescitties vergeleken met individueel brainstormen. Doordat er een verwantschap is tussen de raakstrucruur van probleemanalyse met brainstormen in de groep, kunnen deze verklaringen mogelijk een interpretatiekader vormen voor gevonden effecten. Naast eerder vermeld onderzoek naar de vergelijking van groeps- en individucel product van respectievelijk groeps en individueel brainstormen is onderzoek uitgevoerd naar de effecten van deze groepsactiviteiten op individueel nivo. Dir wordt wel aangeduid als groep-nar-individu transfer. In dit onderzock beperkt men zich mier alleen tot de producten van het groeps en individued brainstormen. maar richt zich ook op de transfer van groepsactiviteiten naar individuele taken. Gabbert, Johnson en Johnson (1986) hebben dergelijk onderzoek uitgevoerd. De centrale vraag in hun onderzoek was of er procesverlies of proceswinst plaatsvinct. De effecten van coöperatieve en individuele leersituaties wetden wat betreft prestaties vergeleken op een aantal taken die verschillende niveaus representeren van Bloom's (1956) taxonomic van cognitieve onderwijsdoden. Een tweeral taken in het onderzok waren brainstormaken. In de coöperatiewe groep werkten studenten in kleine groepen on een groepsproduct te produceren en deden later overeenkomstige raken als individuen. In de individuele groep werkten de studenten alleen om individuele producten te produceren en deden larer overeenkomsrige taken als individuen. Uit de resultaten van hum onderzoek bleek dat de studenten uic de coöperarieve groep op de brainstormtaken beter prestecrden dan de studen- 
ten die individucel brainstormden, dat er transfer van groep naar individu plaatsvond en dat proceswinst en geen procesverlics opurad. Dir onderzock geeft echter geen informatic over de effecten wan brainstormen in de groep op her leren van nieuwe informatie.

De verklaring woor de positieve effecten van interacrie in de kleine groep op het leren van nieuwe informatie word gevonden in de daboratie hyporhese (Schmidr, 1993; Webb, 1989). Eaboraties, zoals het geven van verklaringen die in de groep worden gegenereerd worden verondersteld effectiever te zijn dan individueel gegenerecrde elaboraties. De cognirieve processen die gepaard gatn mer iets aan een ander wir te leggen blijken het leren te bevorderen. Zo kan her geven van verklaringen in de groep de lerende stimuleren tot her verhelderen of reorganiseren van kennis op nieuwe manieren, bewustwording van leemres in kennis, inconsistenties in kennis herkennen en oplossen, nieuwe perspectieven ontwikkelen en meer geclaboreerde verklaringen genereren dan wanneer de lerende de informatie alleen leert (Webb, Troper, \& Fall, 1995). Het verbaliseren van kennis in interactie met anderen heefr volgens Prawar (1989) een grocere bewustwording van die kennis tor gevolg. Pressley er. al., (1992) veronderstellen dat het geven van verklaringen aan anderen meer eisen stelt an de lerende. Samengevar word verondersteld dat her genereren wan verk laringen in de groep leide tor een sterkere organisatie en bewustwording van de kennis in vergelijking tot her individued genereren van verklaringen, waardoor deze kennis meer rocgankelijk en bruikbaar is.

Problemanalyse in de groep stimuleert volgens Schmidt (1982) niet alleen selectieve aandacht, mar ook de organisatie en integratie wan de nieuwe informatie. Problecmanalyse individueel is een methode, die eveneens al deze drie cognitieve procesen veronderstelt. Bij het individued analyseren van een probleem wordt verondersteld dat deze processen in mindere mare arawezig zullen zijn dan bij probleemanalyse in de groep. De reden hierwoor is gelegen in het ontbreken van interactic. Dit veronderstelt een grotere effect bij de elaboratic activiteit in de groep dan bij de individuele activiteit. Op basis wan het onderscheid in verklatende en descriprieve proposities word verwacht dat er tussen de twee vormen van problemanalyse geen verschillen in her parroon van de recall zal zijn. Bij beide groepen worden immers gelijksoortige cogniricve processen verondersteld. De specificke offecten wath problecmanalyse in de groep kunnen pas goed bepald worden wanneer deze vorm van claboratie vergeleken worde met cen zuivere vorm van activatic vin woorkennis, zoals een rechtstreckse vragg nar de betreffende vootkennis ook wel mobilisatie van woorkennis genoend (Peeck 1982a; 1982b). Hicrbij wordt de proefpersoon niet gevraagd iets te verklaren, maar hem of haar wordt gevragd zich reeds bestande kennis te herinneren. Er is geen problecm warvoor ecn verklaring behoeft te worden gegenerecrd. De veronderstelling is dat dir zal leiden tor een vermindering van de mate van elaboratie in vergelijking cot de twee eerder genoende vormen van elaboratie en daardoor wordt ook minder ge- 
leerd. Waarschijnijik zal dit ook een ander recall patroon tot gevolg thebben. Her idee is dat - in vergelijking tot probleemanalyse in de groep en individuele prow blemanalyse - bij deze opdrach wooral minder verklarende proposities worden herinnerd doordat de tak minder stimuleert tot selectieve andacht woor en organisarie van de re leren informarie.

In het in dit hoofdsuk beschreven experiment werd onderzocht wat de relarieve effectiviteit was van probleemanalyse in de groep op her zich herinneren van de rekst wergeleken met individuele probleemanalyse en mer een aak woor voorkennisactivarie. Op basis van de veronderstelde cognirieve processen is de hypothese geformuleerd dat probleemanalyse in de groep leidt toc een betere integratie van de beschikbare kennis met de te leren nieuwe informatie dan respectievelijk de individuele problemanalyse en de taak voorkennisactivatie. Het experiment werd uitgevoerd bij gevorderde studenten die reeds enige tijd geleden dit onderwerp bestudeerd hadden. Als betangriilke afhankelijke variabelen werd het antal correcte proposities (free recall en aanvultoets) dat werd herinnerd gebruikt en het antal verklarende en beschrijuende proposities in de free recall. In dir experiment werden dezelfde materialen en woor een belangrijk deel dezelfde procedures gehanreerd als in her onderzoek naar de differentiële effecten van probleemanalyse bij beginners en gevorderden.

\section{Methode van onderzoek}

\section{Proefpersonen}

Aan het experiment werd door 62 personen deelgenomen: 58 vrouwen en 4 mannen. Hun gemiddelde leefrijd was 18,7 jaar met een standaarddeviatie van 1,2. De proefpersonen waren eerstejaars studenten aan rwee instellingen voor hoger beroepsonderwijs. Alen waren in het bezit wan een HAVO-diploma. Een verdere voorwarde voor deelname was dat proefpersonen geèxamineerd waren in het vak biologie. Homogeniteit wan de proefpersonen met berckking rot voorkennis op het terrein van de biologie was in relatie to de vaagstellingen gewenst. De proefpersonen on rvingen een vergoeding voor hun modewerking.

\section{Materialen}

Het materiaal woor alle groepen bestond uit een tekst over osmose (zic Appendix 1), cen annultoets en een free recall toets. De aanvultoets en de frec recall toets waren dezelfde als die werden gebruike in het onderzock dat in Hoofdlsnuk 3 werd bescheven. De $\alpha$-berouwbarheid (interne consistence) van dere annvulwers was 0.80 . Voor de afzonderlike experimentele groepen waren daar nog problecmbeschrijvingen en wagenlijsten aan roegevoegd. Het probleem bestond wit de beschrijving van het gedrag van een rode blocded in verschillende omstandigheden, dat ook in he in Hoofdstuk 3 beschrever experiment werd gebruikt. "len rode 
bloded is geplaarst in zuiver warer onder een microscoop. De bloedcel zwelt snel en barst uireindelijk. Een andere rode bloedcel wordt roegevoegd aan een oplossing van zout in water en deze schrompelt incen". De proefpersonen kregen ror taak het beschreven gedrag wan de bloedcel te verklaren in termen wan een aan dit gedrag ren grondslag liggend proces, principe of mechanisme. In dit geval het osmorisch proces. Op de Havo wordt Osmose in veet gebruikre biologie handboeken op een min of meer gelijke wijze behandeld, zoals bij inspectie van vier van deze boeken bleek. Dat wil zeggen dat de teksten een vergelijkbare diepgang hadden en vergelijkbare voorbeelden presentecrden.

Een aanvultoets werd gebruikt voor het vaststellen van wat men zich herinnerde van de tekst. Mer behulp van een geconstrueerde tekststructuur (zie Schmide 1982) werden 55 vragen woor de aanvultoers gemaakt die representatief waren voor de rekststructuur. Daarnaast werd gebruik gemaakt van een free recall toers. Tenslotte werden enkele biografische gegevens verzameld zoals leefrijd, gestach en eindajfer biologie op de HAVO.

\section{Procedure}

De proefpersonen werden aselect toegewezen aan één van de drie groepen van het experiment, te weren de problecmanalyse in de groep, de probleemanalyse individucel en de vragg naar voorkennis-groep. Na de randomisarieprocedure werd gecontroleerd in hoeverre de drie groepen vergelijkbaar waren voor zover her biologische voorkennis betrof. Het gemiddelde eindcijfer voor biologic en de standaarddeviatic daarvan in de drie verschillende groepen was: probleemanalyse in de groep gemiddelde 6,66 met een standaard-afwijking van 0,86; probleemanalyse individueel gemiddelde 6,58 mer een standaard-afwijking van 0,69 ; activatie van woorkennis taak gemiddelde 6,42 met een standaardafwijking van 0,96. Deze keine verschillen gaven geen aanleiding om een matching achteraf uit te woeren. De groep probleemanalyse in de groep van 22 personen werd aselect opgedeeld in vier subgroepen van vijf of zes studenten. Aan elk van deze groepen werd cen procfleider toegewezen. In deze groepen vond een analyse van het bloedcelproblecm plats. Allereerse werd kort cen voorbeddprobleem besproken, waarmee her idee van problemanalyse in de groep verthelderd werd. Dit probleem ging over koolstofassimilatic. "Als cen vers takje van waterpest (een planrjo) in een bekerglas met warer geplatast wordt en wervolgens aan zonliche word blootgesteld, komen uit de waterpest al snel gasbelletjes tevoorschiin. Word dit gas in een reageerbuis opgevangen, dan kan men met een gloeiende houtspaander aantonen, dat het ontwijkende gas zuurstof is. Brengr men dir bekerglas mer de waterpest in een donkere ruimte dan houdr de zuturstofproductie al snel op." Daarna werd in de groep het "rode blocdcel probleem geanalyseerd. De probleemanalyse duurde ongeveer vijfricn minuten. De proefleider funktioneerde alls gesprekleider (In Hoofdstuk 3 is de procedure uirgebreider beschreven). 
De groep warin her probleem op individuele wijze werd geanalyscerd volgde dezelfde procedure tot en met de bespreking van her woorbeeld problcem. Daarnat werd nier in de groep over het bloedcelprobleem gediscussieerd, matr mocsten de proefpersonen her probleem individueel analyseren en dir op schrift stellen. De proefpersonen hadden hiervoor vijfrien minuten de rijd.

De groep die tot caak had de voorkennis te activeren verschilde van beide vorige groepen doordat de proefpersonen hier werd gevraagd alles op te schrijwen wat $z$ wisten van Osmose en dit binnen het rijdbestek van vijfrien minuten.

Vervolgens werd aan de drie groepen (probleemanalyse in de groep, problecmanalyse individueel en de groep met als taak de vraag naar voorkennis) de tekst over osmose voorgelegd ter bestudering gedurende exact viftien minuten. Na de bestudering van de tekst werd hun gevraagd de free recall en de anvultocts te maken.

\section{Analyse}

Scoring: De protocallen van de free recall zijn door acht beoordelaars geanalyseerd. Van tevoren hadden zij een training gehad gerichr op her scoren van free recall protocollen. Allereerst werden de door de proefpersonen geproduccerde free recall protocollen door ona hankelijke beoordelaars onderverdeeld in onderwerpgezegde eenheden (of proposities), die een enkel idee weergeven. De overeenstemming tussen beoordelaars bij deze tak was $96 \%$. Vervolgens ward clka proposiric ap correctheid gecontroleerd. De overeenstemming tussen beoordelaars hierbij was $75 \%$ ). Verschillen russen beoordelaars werden door discussic opgelost. Verder werden de proposities gecategoriseerd als zijnde verklarend of descripticf van aard. (interbeoordelaars betrouwbaarheid $85 \%$ ). Een verklarende propositic werd gedefinieerd als een verklaring die of een proces karakteriseert, of een voorwarde beschrijfe waaronder een proces platarsindt. Alle andere proposities werden beschouwd als descriptief (zie voor voorbeelden wan verklarende en beschrijvende proposities Hoofdstuk 3).

Voor het vaststellen van de kwandiaticye effecten van de werschillende groepen zijn bij de free recall toers herhadde meting variantic analyses uiggevocrd met én tussen proefpersonen (condicie) Gactor en én binnen proefpersonen fixtor (het onderscheid in verklarende versus descriprieve proposities dat worde herimerd). Bij de anvulroers is woor de analyse van de data ANOVA gebruikt.

\section{Resultaten}

Free recall

De resultaten voor her anal correct verklarende proposities on het aantal correct beschrijwende proposities staan vermeld in Tabel 4.1 . 
Tabel 4.1. Germided antal correct verharende en comect beschipuende proposities voor de dre verschillende groepen.

\begin{tabular}{|c|c|c|c|}
\hline & gem & so & $n$ \\
\hline Activatie woorkennis tak & 32,2 & 129 & 20 \\
\hline Verklarend & 18.7 & 9.2 & \\
\hline Beschivivend & 13,5 & 9,3 & \\
\hline Probleemanalyse individueel & 39,8 & 20,0 & 20 \\
\hline Verklareind & 25,8 & 16,4 & \\
\hline Beschilvend & 14,0 & 7,5 & \\
\hline Probleemanalyse groep & 43,2 & 10,8 & 22 \\
\hline Verklarend & 26,4 & 8,4 & \\
\hline Beschrimend & 16,8 & 6,6 & \\
\hline
\end{tabular}

De herhaalde mering variantic analyse van de free recall gaf de volgende resultaten: Een marginaal verschil werd gevonden tussen de groepen problemanalyse in de grocp, de individuele problemanalyse en de individuele activatie van voorkennistak wat betreft de total antal correct herinnerde proposities, $F(1,59)=2,93$, $M S_{\mathrm{p}}=112.39, p=0,061$. Hoewel de trend overeenkomt mer de veronderstelde toename aan correct herinnerde proposites op basis van de elaborarie hypothese aijn de verschillen klein en valt verder wooral de grore standaarddeviarie bij de groep problemanalyse individueel op (zie Tabel 4.1). Blijkbaar stimuleert problemanalyse individuee bij een bepaald aantal studenten srerk de elaboratie, matr dit is bij een antal studenten juist ook nier her geval.

Uir de analyses blijkt verder dat significant meer verklarende proposities dan descriptieve proposities van de tekst werden herinnerd, $F(1,59)=27,11, M S=$ $89,03, p<0,001$. Er is geen significante interactic tussen treatment en type propositic, $f(1,59)=1,26, M S_{c}=89,03, p=0,29$.

lir werd verondersted dat de toename in elaboratic en dardoor organisatie en bewuswording van de kennis in de verschillende groepen in dit onderzoek zal leiden tor cen ander patroon in de recall voonal wat betreft de vergelijking tussen de groep acrivaric wan woorkennistaak mer de wee andere groepen re weten probleemanalyse individued on problecmatnalyse in de groep. Verondersteld werd dat het aantal verklarende proposities in de recall meer zou roenemen in vergelijking tor de beschrijuende propositics in de recall. Wit Tabel 4. 1 blijk inderdaad dat de groepen problcemanalysc individueel en problecmanalyse in de groep in vergelijking tot de groep accivatie wan voorkennistak nelatief meer verklarende proposities herinneren dan beschijpende proposities. Er is echter geen interactie-effect tussen treatment en type propositie. Uit Tabel 4 . I blijk dat de groep probleemanalyse vooral 
Tabel 4.2. Gemiddelden en standaarddevaties van het aantal correct beantwoorde iterns uit de aanvultoets.

$\begin{array}{llll}\text { groepen } & \text { gem } & \text { sd } & n \\ \text { Vraag naar voorkennis taak } & 33,05 & 4,65 & 20 \\ \text { Individuele Probleemanalyse } & 34,95 & 6,22 & 20 \\ \text { Probleemanalyse in de groep } & 37,23 & 4,37 & 22\end{array}$

een grote standaarddeviatie lat zien bij verklarende proposities en niet bij descriptieve proposinies.

\section{Aanvultoets}

In Tabel 4.2 zijn voor de drie groepen de gemiddelde antallen goed beantwoorde items uir de aanvultoers weergegeven met daarbij de standaarddeviaties.

De variantie analyse gaf de volgende resultaten: Er werd een significant verschil gevonden tussen de groepen probleemanalyse in de groep, individuele probleemanalyse en de activatie van voorkennistaak wat betreft de totaal antal correct herinnerde irems uit de aanvultoets $F(1,59)=3,51, M S_{0}=26,23, p<0,05$. De lineare component in het effect blijkt significant te zijn $F(1,59)=4,71, M S_{c}=26,23, p<$ 0,05 , terwijl er geen sprake is van significante afwijkingen van lineariteit $F(1,59)=$ $2,30, M S_{e}=26,23, p=0,13$. De veronderstelling was dat de mate van elaboratic zou toenemen in respectievelijk de groepen vraag naar voorkennistak, de individuele probleemanalyse en de probleemanalyse in de groep en dat daardoor er een grotere organisarie en bewustwording van de kennis zou ontstaan waardoor deze kennis meer roegankelijk en bruikbaar zou zijn. Mer andere woorden meer claboratie zou to het zich beter herinneren wan de informatie uit de tekst leiden. De resulaten bevestigen dewe hypothese.

Pose hoc analyses (Tukey) laten een signifucant verschil zien tussen de gemiddetden van de groepen activarie wan voorkennis en problemanalyse in de groep $(t 59)=1,52, p<0,05)$. De verschillen tussen de groepen problecmanalyse indiwiduee en probleemanatyse in de groep zijn klein en niet significant $(n(59)=1,58, p$ $=0,33$. Ook de verschillen tussen de gemiddelden van de groepen vrag naar voorkennis raak en de individuele probleemanalyse zijn nier significant $(f(59)$ $=1,62, p=0,47$ ). Exenals bij de free recall is er ook bij de anvultoes een relaricf grotere standaarddeviatie bij de groep probleemanalyse individued in vergelijking tot de rwee andere groepen. 


\section{Discussie}

Her doel van deze studie was na te gaan war de differentiele effecten zijn van problemanalyse in een groep versus probleemanalyse individueel en een acrivarie wan woorken mistaak. Kenmerkend verschil cussen problemanalyse in de groep en de individuele vormen van elaboratie is interactie. Uir de onderzoeksliteratuur is duidelijk geworden dat interactie positieve, maar ook negatieve effecten kan hebben op leerresultaten. Uit de resultaten van dit onderzoek blijkt dat interactie in de grocp (door middel van probleemanalyse in de groep) in vergelijking tor geen inreractic cen positicf effect heeft op het leren en onthouden wan een tckst die relewant is voor her probleem. In sterkere mate dan de free recall blijkt dit uir de resultaten van de aanvultoets. Hoewel de gevonden verschillen tussen de drie groepen klein zijn is de trend duidelijk en konsistent voor wat betreft de free recall en de an wul toets. Er is bijvoorbeeld een lineair verband tussen de verondersrelde roename in claborarie acriviteiten tijdens de verschillende groepen in dit onderzoek en her tocaal aantal correc herinnerde proposities in de aanvultoets. Deze resultaren bevestigen de positieve resultaten uir de onderzoekstiteratuur wat betreft de effecten van bepaalde rypen interactics in de groep op de leerprestaties van lerenden (Webb \& Sullivan-Palincsar, 1996; Pressley er. al., 1992). De rheorievorming uir het brainstorm onderzoek over de mogelijk negatieve effecten van interactie tijdens her genereren van ideeën (Dichl \& Stroebe, 1987; McMullen \& Johnson, 1991: Stroebe \& Dichl, 1994) bieden echter een mogelijke interpretatie voor de keine verschillen tussen groeps-en individuele probleemanalyse. Wat berreft het patroon van de recall, deze kwam overeen met de verwachring, al waren de verschillen te klein om significant te zijn.

Hoe zijn deze resultaten nu te interpreteren wanuic de verschillende hypotheses voor de effecten van probleemanalyse, zoals deze in Hoofdstuk 2 beschreven zijn? Ook bij dic onderzock kunnen, evenals in het onderzock warover gerapporteerd is in Hoofdstuk 3, de movivarie hypothese, de selecrieve-aandacht hyporhese en de elaboratic hypothese gebruikr worden voor de verklaring van de gevonden resultaw ten. De ecrste mogelijke verklaring kan de motivarie van studenten betreffen. De veronderstelling is dat interactic tot cen grotere bewustwording van leemtes in de voorkennis kan leiden. Dit zou kunnen betekenen dat in de groep waar probleenamalyse in groepswerband werd uirgevoerd in wergelijking tot de groepen individuele problecmanalyse en de activatic van voorkennistak een sterkere morivatie anwexig zou zijn en datrdoor zullen ze meer leren en onchouden van de studietekst. $\mathrm{D}_{\mathfrak{C}}$ resultaten win dir onderzock kunnen de mogelijkheid van deze verklaring onderstcunen want de groep probleemanalyse in de groep heef in vergelijking tor de twee andere groepen neer ondhouden van de studietekst. De motivatie hypothese makar echter niet duidelijk waarom in her bijzonder werklarende informatie beter herinnerd word. 
Een andere verklaring van de resultaten is mogelijk op basis wan selectieve atmdacht. In deze theorie word gesteld dat voofal takwariabelen van inwoed aijn op de aandach die men besteedt aan verschillende onderdelen van de te bestuderen studietekst. De grotere aandache voor deze onderdelen zou leiden tor het beter herinneren van deze informatie. Deze hypothese kan dus verklaren warom de groepen warin het probleem geanalyseerd wordt de verklarende informatie uit de srudierekst berer onthouden dan de groep acrivatie van voorkennistaak. In deze latste groep kan zowel aandacht besteed worden an verklaringen als beschrijwingen. Deze hyporhese kan echter niet verklaren warom her herinneren van de beschrijende informatie niet slechrer was in de groepen die problecmanalyse gebruikren in vergelijking tor de groep activatie van woorkennis op basis van minder aandacht geven aan die elementen van de tekst.

De derde mogelijke verklaring voor de gevonden resulaten is de elaborarie hypothese. Deze hypothese gat uit van her idee dat door elaboratic (door middel van het zelf genereren van verklaringen en mentale model en) er cen berere organisaric en bewustwording van die kennis tor stand komt en dardoor een betere tocgankelijkheid en bruikbatheid van deze kennis. Deze hypothese verk.tart zowel de grorere effecten voor de groep waarin probleemanallyse groepsgewijs plaarswindr als de (lineaire) roename in de geheugenprestatic bij de drie opeenvolgende groepen in dit onderzoek, respectievelijk activatie van voorkennistaak, individucle probleemanalyse en probleemanalyse in de groep. Teven verklaart dexe claboratic hyporlac se her patroon in de recall, dat er namelijk relarief meer verklarende proposities dan beschrijvende proposities worden herimnerd.

In dit onderzoek stond de rol van interactie voor her leerproces van studenten centraal. Probleemanalyse als manier van werken was voor deze studenten nieuw. Uit onderzoek blijkr dar slechts bepaalde wormen van interactie positieve effecten hebben op leerprestaries. Een beperking van dit onderzock was dar de proefpersonen nier getraind waren in problecmgestuurd leren en darmec ook nien getraind en geofend in her realiseren van een effecticke interactic binnen de context van probleemgestuurd leren. Dit kan mogelijk van invloed zijn geweest op de resultaten verkregen in dit onderzock. 

Hootdstuk 5

\section{Effecten van probleemanalyse in een kleine groep op het leren van een tekst bij eerstejaars medische studenten'}




\section{Inleiding}

Problecmanalyse in de groep, zoals in Hoofdstuk I beschreven, is een onderwijsprocedure die erop gericht is om de interactie ve vergroten tussen de reeds aanwezige kennis en de nieuwe nog te leren informatie. De veronderstelling is dat deze procedure de integratie van de nieuwe informatie in het reeds aanwezige kennisbestand bevordert. In Hoofdstuk 3 en 4 zijn experimenten beschreven waarin verschillende effecten gevonden werden die deze veronderstelling ondersteunen. Probleemgestuurd onderwijs was echter voor de betrokken proefpersonen in de ecrste twee experimenten een betrekkelijk nieuwe, hen onbekende, onderwijsmethode. Ook waren deze proefpersonen niet gerraind in het doen van een probleemanalyse. De studie die in dit Hoofdsruk wordt beschreven richt zich op de wraag of deze effecten ookgevonden zouden kunnen worden in een meer naturulijke context, een contexr met een grotere ecologische validireic. Het belang van dezc cologische validitcit wordt door Webb $(1996, p 867)$ als volgt geformuleerd: "Small group learning cannor be examined independencly of the curriculum, the culture of the classroom, assessment practices and the instructional climare of the classroom". Een dergelijke concext wordt verschaft door het curriculum van de studie geneeskunde an de Universiteit Maastricht, dat gebaseerd is op probleemgestuurd leren.

Kenmerken van het probleem als startpunt voor het leerproces in de kleine groep is in de theorie over probleemgesturd leren een belangrijke variabele (Schmidt, 1994; Schmidt \& Moust, 1995). De experimenten die beschreven zijn in Hoofdstuk 3 en 4 makken gebruik van een relatief eenvoudig probleem als startpunt voor de probleemanalyse. Het bloedcelprobleem is bijwoorbeeld cen kwalitatief geherformuleerd woorbeeld uir leerboeken voor de biologie in her voortgezet onderwijs. In de studie genceskunde aan de Universiteit Maastricht wordr gebruik gemaakt van complexere problemen alls uitgangspunt voor probleemgestuurd teren. De complexiteit zit vooral in her gegeven dat het problem multidisciplinair van arard is. Her probleem is zo geformuleerd dat bij het oplossen van her probleen kennis werondersteld wond uit meendere disciplines. Was bij het bloedcelproblecm de problecmstelling relatief cenduidig (verklaar her zwellen, incenschrompelen van de bloedcel) bij de problemen die aan studenten gepresenteed worden in de studie geneeskunde in Maastricht is dat complexer, dat wil zeggen men noet zalf ele probleemstellingen genereren. Verder is or in de studic genceskunde veetal sprake van en reëel probleem en niet een probleem gebaseerd op een laboratoriumonderzock, zoals her bloedcelprobleem. Een reè omschreven probleem kan zelfs zo recel zijn dat de student ey zelf ervaring ermee heef of dat her is ervaren in de direcre ongeving. Her problecm is verder reëel, in die zin dat her voorkome in het curriculum van een studie geneeskunde dat gebaseerd is op probleemgestuurd 
leren. Het is zo geformuleerd dar het afgestemd is op de wookennis van de studenten in die fase van de srudic.

In de experimenten uit Hoofdsuk 3 en 4 werd gebruik gemaakt van proefpersonen die onervaren waren met de methode van probleemgestuurd leren. Wir een overzicht van onderzoek nar coöperatief leren (Webb, 1906) blizkt dau srudenten die getraind zijn in coöperarief leten betere interacte in de groep en ook een grotere leerwinst laten zien. Deze rraining was of gerichr op een verbetering van de samenwerking in de groep of op een verberering van de leervaardigheden zoals $\mathrm{ef}$ fectief uideggen aan elkaar en effectief vangen aan elkaar. Sommige trainingsprom gramma's waren op beide aspecten gericht. Het onderzoek van Bielacryc, Pirolli en Brown (1995) illustreer her belang van raining van studievardigheden zoals het zelf verklaringen genereren en zelfregulatiestrategieön voor het leren oplossen van problemen. Zij onderzochen de invloed van deze training op her gebruik van verklaringen door studenten en het effect ervan op een test voor problcemoplassen. Vierentwintig studenten die geen ervaring in programmeren hadden volgden een serie programmeerlessen. Na enkele introductielessen kwamen de dechnemers aan het onderzoek in twee groepen terecht. De ene groep kreeg wel en de andere groep geen training in de eerder genoemde studiewardigheden. De groep die instructie had onrvangen vercoonde significant grotere leewinst in her gebruik van het zelf genereren van verklaringen en strategicën voor zelfregularic. Dit toegenomen gebruik van dergelijke studiestrategieën werd vergezeld door een betere presratie op de test voor probleemoplossen. King $(1992 ; 1994)$ onderzocht of studenren die getraind waren in vragen stellen voor gebruik in groepsverband betere leerprestaties hadden dan ongetrainde studenten. Uit de onderzocksresultaten bleek dat de groep die vooraf training kreeg in het stellen wan wagen betere leerprestaties behaalde dan de groep die geen training kreeg. Uir het onderzoek naar brainstormen in de groep blijkr dar training in brainstormen positieve of gemengde effecten heefe (Lamm \& Trommsdorf, 1973; Mullen \& Johunson, 1991). Naast expliciete training in groeps- en studievaardigheden moer genuend worden de tijd die studenten hebben om te oefenen in groepen. In de studic in Marsirtuch hobhen de studenten niet alleen training gehad maar hebben ook gedurende lange tijel kunnen ofenen mer problemanalyse. Training en ofening in problecmanalyse wordt verondersteld een positief effecr te hebben op de kwaliteit van de interacrie in de groep en daannee mogelijk op de mate van claboratie (aic het model van Webb (1996) voor de relatie russen unpurvariabeten en proceswariabelen).

Een andere variabele die verwache mag worden wan invloed re zijn op de problemanalyse is de hoeveelheid rijd die aan deze acciviteit wordt besteed. I n de experimenten die beschreven aijn in Hoofdstuk 3 en Hoofdstuk 4 werd slechts kort rijd besteed an de problemanalyse, ongeveer 15 minuren. Dere fasc kost in con onderwijggroep in een bestaand curriculum van de medische sudic duadelijk meer rijd, zeker 30 a 40 minuten, warna men begint met het formuleron van de leer- 
doelen. Hoewel er een relatie kan zijn tussen de complexiteit van het re verklaren probleen en de rijd die nodig is voor de probleemanalyse, lijk de rijdsvariabele van belang gezien de mogelike invloed ervan op de cognitieve processen die plaarswinden in de groep.

Doel van de studie die hier wordr beschreven is na re gaan of de effecten van probleemanalyse in de onderwijsgroep op het leren van studenten ook bij cen meer ecologisch valide leeromgeving waar te nemen zijn. De hyporhese is dat ook hier probieemanalyse in de groep leidt rot beter leren en onthouden van de sudietekst en ror en ander patroon van recall. Probleemanalyse wordt verondersteld van invloed te zijn op de integratie van de nieuwe informatic in het oude kennisbestand. Doordat problecmanalyse feidr tor elaboratie zal er een betere organisatie en bewustwording van de kennis zijn (Prawat, 1989). Een belangrijk kenmerk van geïnregreerde keninis is de organisarie van die kennis. Deze berer georganiseerde kennis zal beter toegankelijk en bruikbaar zijn en zal daardoor tot een betere recall leiden zan de bestudeerde tekst.

Volgens Mayer (1989a) zal probleemanalyse daarnaast vooral leiden tot een verbeterde recall van de meer belangrijke informatie in de tekst. De veronderstelling hierbij is dat probleemanalyse de studenten helpe de aandacht te richten op de verklarende informatie in de tekst. Het antal verklarende proposities dat worde herinnerd is daarbij een indicaror voor de integratie van de nieuwe informatic in her bestaande kennisbestand. Volgens Mayer is het aantal verklarende propositjes in free recall een gevolige maat voor de diepte van integratie wan leerstof in bestaande kennisstructuren.

Een andere hypothese is dat de probleemanalyse de recall van letrerlijke informatie uit de vekst zal verminderen (Mayer 1989a). De veronderstelling die hieraan ten grondslag ligt, is dat probleemanalyse studenten helpe de leerstof te reorganiseren zodat deze past bij hun conceptueel model; wanneer studenten actief her marerial reorganiseren, neigen ze ertoe de letterlijke informatie te vergeren en dit leidr tot cen tocname van her antal inferenties in de recall. Een andere maat voor her vaststellen van de mate van integratic van de nieuwe informatie mer de bestaande kennis is dus he afthat inferenties in de recall. Wanneer men een tekst bestudect gaa men meestal verder dan de informatie in de tekst zelf om deze te kunnen begripen en te herinneren. Interacties tussen voorkennis en de rekst komen vooral voor bij her maken van inferenties. Het maken wan inferenties maake her constructieve karakter van het bestuderen van een tekst duidelijk. Probleemanalyse in de groep worde verondersteld her maken van inferenties tijdens her bestuderen wan een rekst te bevorderen. Dir leidt tot her nier meer duidelijk kunnen onderscheiden van wat voorkennis is en wat in de rekst stond. Daardoor zullen er meer inferenties in de recall zijin.

In het hier te rapporteren experiment werden de effecten van probleemanalyse op het leren van cen daaropvolgende studietekst onderzocht. De proefpersonen ana- 
Iyseerden een relevant probleem of een controleprobleem voorafgande an het bestuderen van een teks om de mogelijke effecten van probleemanalyse in cen feirelijke onderwijscontext te onderzoeken. Proefpersonen die aan dir experimen deelnamen hadden al meer dan drie maanden ervaring met problecmgestuurd onderwijs. De belangrijkste afhankelijke variabelen in de te rapporteren analyses waren thet aantal correcte proposities, het aantal verklarende en beschrijvende proposiries, en het aantal inferenties in de free recall. Dit experiment betrefr de vaig of probleemanalyse voorafgande an her verwerken wan een relevante tekst het begrijpen van informatie uit die tekst vergemakkelijkr.

\section{Methode}

\section{Proefpersonen}

Proefpersonen waren 48 eerstejars medische studenten (21 mannen en 27 vrouwen) die ruim drie maanden geneeskunde studeerden an de Universitcit van Maastriche. Zij kwamen direct van her $\mathrm{VWO}$ en hadden allen biologie en natuurkunde in hun vakkenpakket. Deze medische studenten functioneerden in cen curriculum dat is gebaseerd op probleemgestuurd leren. In her eerste onderwijsblok van de studie geneeskunde, dat zes weken duurt, hadden zij cen uitgebreide introductie gehad in de merhode wan werken in de onderwijsgroepen. In de daropvolgende blokken werd ook nog explicier aandacht besteed an de methodle van werken. De studenten leerden dus wanal het eerste moment in de studie hoe zii probleemgestuurd leren in de onderwijsgroep op een optimale wijze moeten uitvoeren.

De studenten hadden op het VWO basale voorkennis opgedaan omtrent de bloedcirculatie. Zij hadden in de eerste drie onderwijsblokken relevante voorkennis opgedaan die noodzakelijk is voor her leren van dit nieuwe onderwerp. Deze kennis betreft vooral kennis over het zenuwstelsel in het derde onderwijsblok. De proefpersonen werden at random toegewezen aan de condities wan het experiment, watrdoor negen groepen werden gecrecerd: vijfexperimente grocpen en vier controlegroepen. 


\section{Materialen}

De materialen bestonden uit wee problembeschrivingen, een leertekst en een frec recall toets. De problembeschrijung voor de experimentele groep bestond uir en problem dat feitelijk in her onderwijs wordt gebrukt, namelijk her tweede problem uit het wijde onderwigblok van her erste studiejar. Dir blok heef als tirel: "Ontregeling Geregeld". Het problem behoort bij het eerste subthema (blocdcircularie) wast dit blok. De tekst van her probleem luide als volgt:

\section{Een stekelig voorval}

Dhr. Laeven heeft cen hobby die de meesten van ons op zijn zaches gezegd nogal eng vinden Hij heeftachter in z'n ruin een aantal bijerkorven. Elke ochtend gat hij cerst even bij zin bijem op bezock. Achrer in de tuin aangekomen, struikel hij en valt tegen de korf aan. De rest laat zich raden. Hij kan nog snel terug het hur ingaan en zijn vouw walschuwen. Deze belt de huisarts.

Dhr. Laeven heeft hevge pinn ande steekwonden en na een minuut of vif begint bij zich flaww te voelen. Hij word duizelig. Her zwer breekt hem uit en hij wordt misselijk. De huisarts is een kwartier later aanwezig. Hij ziet een man met een nomaal bewustzijn. Zijn ademhaling is regelmarig. De huisarts telt en polsfrequentie van 88 slagen per minut en meer de bloeddruk: 120/80 mmHG. Hij besluit 5 minuten af te wachten en meet dan cen polsfrequentie van 104 slagen per minuut. De bloeddruk is dan $115 / 80$ $\mathrm{mmHg}$. Weer 5 minuten later is de pols 120 slagen per minut en de bloeddruk $85 / 55 \mathrm{mmHg}$. De acra (uitstekende ledematen) voelen warm aan. De huisarts spuit intraveneus adrenaline.

De problecmbeschrijwing voor de controlegroep was een tak uit her edrte blok van het weede jare, die gericht was op het opdoen wan basale kennis over bewustzijn, zintuigen en emories. Het problecm was zo gekrozen dat dit niet gerelateerd was an het onderwerp van het stokelig voorval probleem, namelijk bloeddrukregulatie, nat wel in gelijke mate aansloot bij de voorkennis wan studenten. De tekst van het probleem luide als volgt" 


\section{Een blik te wer}

Jan Willem Prins, 4 jaar oud, heeft onlangs een flinke griep gehad. Zijn moeder was het opgevallen dat hij sinds die griep was gaan loensen. Zij had aen afspraak gemaakr bij de huisarts. De huisarts wroeg haar Jan Willem op schoot te nemen en zijn linkeroog met haar linkerhand af te dekken. Op een afstand van 4 meter wijst de huisarts plaatjes aan op een kaart. Jan Willem kan alle plaarjes benoemen. Na het afdekken wn het rechteroog kan Jan Willem alleen de kleinste plaatjes niet benoemen. Daarna krijgt Jan Willem een bril op met een rood glas voor het rechteroog en een groen glas voor het linkeroog. Met stereogrammen test de huisarts het dieptezien. Jan Wrillem kan geen van de figuren herkennen: zijn dieptezien is ernstig gestoord. Tenslotte doet de huisarts een afdekrest. Tellkens als hij het linkeroog van Jan Willem afdekt, blijkt het rechteroog naar buiten bewegen. Als hij het rechreroog afdekt, blijft het linkeroog in dezelfde positie. Het valt de huisarts op dat de moeder een bril op heeft met glazen die haar ogen sterk vergroten. Hij wraagt of het scheelzien in de familie voorkomr. Zij bevestigt dit en vertelt dat zij vroeger een lui oog heeft gehad, waarvoor zij mer een bril en afplakken van her linkeroog is behandeld.

De in dit experiment gebruikte leertekst beschrijft het proces van bloeddrukregularie (zie Appendix 2). De tekst heeft een basale structuur van: 1. inleiding, warin opgenomen de belangrijkste factoren van invloed op bloeddrukregulatie; 2. druk en stroming in het vaatstelsel; hemodynamica; 3 . drukwerval in her vaatstelsel; drie compartimenten; 4 . regeling van de hartprestarie; 5 . korte termijn regulatie van de bloeddruk en 6 . shock. De studierekst is samengesteld uir gedeelen van verschillende handboeken. De tekst is woomamelijk een selectic van gededtes $(2,3,4 \mathrm{cn}$ 5) uir een bekend handboek voor de fysiologic (Bernards \& Bouwman, 1988). Naar dit handboek wordt ook in het blok, waar he bijensteck problecm vandaan komt, verwezen en her wordr ook veel gebrukt door studenten. Voor de in leiding (1) is gebruik gemalkt van een gedeelte uit een goed Engelstalighandbock voor fysiologic van hart en watscelsel (Berne \& Levy, 1992). Voor her gedeetre over shock (6) is gebruik gemaakt van een gedectre uit Handbook of Physiology (Guyton, 1991). De opbouw van de tekst lijkr erg op die van andere reksten in de handbocken. In totaal was deze tekst tien pagina's lang. De tekst bestond uit in total 347 proposities en 2556 woorden.

De free recall roets bestond uit drie witte pagina's en een voorpagina men de volgende instructie: "schrijf alles op war je heminnert van de tekst over bloeddrukregularie." 


\section{Procedure}

De profpersonen werden asdect toegewezen aan én van de twee groepen van her cxperment, te weten de experimentele groep warin en relevant probleem wend geanalyseen $(n=27)$ en de controlegroep $(n=21)$. Na de randomisatic-procedure werd gecontroleerd in hoevere de twee groeper vergelikbaat waren voor zover her de biologische en natuurkundige vootkennis betrof. Het gemiddelde eindcijfer voor biologie in de experimentele groep was gelijk aan 7, 11 met ecn standaarddeviatic van 0,75. De controlegroep had een gemiddeld eindcifer van 7,00 met cen standaardafwjiking van 0,77. Het gemiddelde eindcijer voor naturkunde voor de experimentele groep was 6,70 met een standardahwijking van 0,91. De controlegroep had cen gemiddeld eindeifer wan 6,74 en een standaardafwijking van 0,93 . Dere kleine verschillen gaven geon aanleiding on een natching achteraf uir te voeren.

De experimentele groep van 27 personen werd aselect opgedeeld in vijf subgroepen van drie keer vijfen twee keer zes studenten. De controlegroep van 21 personen werd aselect opgededd in wier subgroepen van rwee keer vijf en rwee keer zes studenton. Aan clk van deze groepen werd een proefleider tocgewezen.

Het moment warop het experiment werd uitgevoerd, viel samen met het latste gededte wan het derde onderwijsblok; op een moment dus dat de studenten rele. vante voorkennis haddon opgedaan. In de periode rot aan Blok 5 kwamen geen onderwerpen aan de orde die direct te maken hadden met het onderwerp bloeddrukregularie. Het experiment vond plats in ruimres war men normal gesproken ook bijeenkomsten wan onderwijggroepen had. Van in totaal negen ruimtes is gebruik gemakt. In deze rumtes hadden de groepen de beschikking over bord en Hap-over. Her experiment vond plaars op een ochtend wa arop studenten verder geen geplande onderwijsactivitenten hadden.

In de experimentele groep werd her "Stekelig voorval" probleem geanalyseerd. In de connolw groep werd het probleem "Een blik te wer" geanalyseerd. Verder voerden ale practpersonen onder de rwe condities dezelfe activiciten wit.

Als procheider con gespekleder fungerden vierdakars medische studenen, die in het verken ooit hetzolfe probleem geanalyseerd hadden. Deze studenten hadden ruim drie far ervang met de utvoering van de rol van gesprekleider. In iedere groep legde de proefleider an de proefpersonen wit water wan hen werd verwach. Bij het presenteren van het probleem werd kort zijn context angeduid. Bij her stekclig voorwal problecm werd anngegeven dat her paste bij het onderwerp circulatic. Bij her "en blik te ver" probleem werd angegeven dat het onderdeel wan cen blok over bewustijn, zintugen en conotios was. Na het lezen van het probleem begonnen de studenten cerst kor het problem te defimieren ( 5 minuten) en darna werd er gedurende 30 minuten gebrainstormd. De experimentele proefperso"con analysecten her "stekelig voorval" problom, terwijl de controle groepen het "Fen blik re ver" probleem analysecten. De proefleider trad op als gesprekleider 
en gaf regelmarig samenvartingen wan de verschillende opvatcingen. Verder stimuleerde hijlzij de groep tor het produceren van verklaringen en her notuleren van deze geproduceerde verklaringen op tlap-over en/of bord. De gesprekleider had vooraf instrucries gehad hoe in deze te handelen. Hij of zij had daamaast de opdrach gekregen geen aanwijzingen te geven waruit de gropp zou kunnen afleiden wat juist of onjuist was; en of de gegeven verklaringen belangrijk of minder belangrijk waren. Doordat de discussie op de band werd opgenomen, kon er geverifieerd worden of er door de proefleider geen informarie werd gegeven watuir proefpersonen konden afleiden welke onderliggende fysiologische mechanismen bij beide problemen van belang waren.

Na de probleemanalyse werd aan de proefpersonen uir beide condities de studietekst over bloeddrukregulatie gegeven. In de experimentele groepen werden vooraf de Aap-overs met de neerslag van de probleemanalyse verwijderd. De rijd beschikbaar voor her bestuderen wan deze tekst was 30 minuten. Het was toegestaan aantekeningen te maken in de rekse. Na 30 minuten werd de studietekst ingenomen. Daaropvolgend werd de free recall toets over bloeddrukregulatie aangeboden aan zowel de experimentele als de controle groep. Er was geen tijdslimier gesteld aan de beanrwoording van de free recall toets.

\section{Analyse}

Allereerse werden de door de proefpersonen geproduceede free recall protocollen door rwee onafhankelijke beoordelaars onderverdeeld in onderwerp-gezegde cenheden (of proposinies), die elk een enkel idee weergeven (zie voor een gedetailleerde bespreking van deze analysemethode Hoofdstuk 3). De overeenstemming tussen deze beoordelaars voor deze taak was $96 \%$.

De 47 protocollen werden verdeeld over twee beoordelaars die de geproduceerde proposicies vervolgens beoordeelden op correcheid. Daarna werden van alle 47 prococollen de proposities opmicuw beoordceld door wwe andere beoodelatars. De overeenstemming russen de eerste en de rwede boordeling was $87 \%$.

Daarop werden de proposities door twce beoordelaurs gecaregoriseerd als zijnde verklarend of descriptief van ard (een gedecailleerde bespreking van dec analysemerhode is weer te vinden in Hoofdstuk 3). Meningsverschillen tussen beoordeJaars werden opgelost door discussie. Door een onalhankelijk beoordelaar is een steekproef van vijftien protocollen beoordeeld wat betreft het onderscheid in verKlarende en descriprieve proposiries. De overeenstemming ussen de eerste en de weede beoordeling voor deze categorisering van proposities was $86 \%$.

De proposities werden ook gemarched met de oorspronkelijke tekst. Er werd bepaald of de propositic en lerrerlijke weergave of parafrase was van de rekst of dar het een inferentie betrof. Dat wil zeggen informatie in de protocollen die uitsrijg boven de informatie in de studierekst. Op basis wan matching van de prorocollen 
Tabel 5.4. Gemiddelden en standadrddeviates woor hel aantal correct verkiarende en correct beschrivende propostives.

$\begin{array}{cccc} & \text { gem } & \text { sd } & \text { n } \\ \text { Stekelig woorval probleem } & 50,1 & 9,7 & 27 \\ \text { Verkiarende proposities } & 25,0 & 6,1 & \\ \text { Beschrivende proposites } & 25,1 & 6,9 & \\ \text { Controle probleem } & 40,5 & 11,8 & 21 \\ \text { Verklarende proposities } & 20,1 & 7,3 & \\ \text { Beschrijuende proposities } & 20,3 & 5,6 & \end{array}$

mer de studietekst werd her aantal geproduceerde inferenties bepald. Verschillen tussen beoordeldars werden opgelost door middel van discussie. Door een onafhankelijke beoordelaar is een steekproef wan viftien protocollen beoordeeld wat betreft deze matching van de protocollen mer de studierekst. De overeenstemming tussen de eerste en de tweede beoordeling van proposities was $83 \%$.

\section{Resultaten}

Free recall

De resultaten voor het aantal correct verklarende proposities en het aantal correct beschrijvende proposities staan vermeld in Tabel 5.1.

De variantie analyse van de free recall gaf de volgende resultaten: Een significant verschil werd gevonden russen de groepen stekelig voorval probleem en controleprobleem wat betreft de total antal correct herinnerde proposities, $F(1,46)=$ $9,68, M S_{c}=56.53, p<0,01$. De groep warin her stekelig voorval werd geanalyseerd produceert dus significant meer correcte propositics dan de controle groep. Hiermec wordt de hypothese ondersteund dat problecmanalyse voorafgande an de re leren studierckst, ook in een cologisch valide onderzoek, leido tor het beter on houden van informatie uir die tekst. Uit de analyses blijkr verder dat er niet significant meer verklarende proposities dan descriptieve proposities van de tekst werden herimerd, $M(1,46)=0,03, M S_{c^{\prime}}=29,28, p=0,86$. Ook is er geen significante intencrie tussen type geanalyseerd problecm en type propositic, $F(1,46)=$ $0,001, M S_{c}=29,28, p=0,98$. De hypothese was dat de groep met het stekelig vompal probleen in vergelijking rot de controlegroep een groter antal verklarende dan beschrijuende proposities in de recall zou laten zien door de integratie van de voorkennis met de nieuw te leren informarie. Deze hyporhese wordt door de onderzocksresultaten niet bevestigd. Her gemiddeld antal correcte verklatende proposities geproduceerd door de experimentele groep verschilt wel significane van her gemideteld anntal correcte verklarende proposicies geproduceerd door de 
Tabel 5.2. Gemiddelden en standaarddeviaties voor aantal geproduceede inferenties.

$\begin{array}{lrll} & \text { gem } & \text { sd } & n \\ \text { Stekelig woonal probleem } & 9.56 & 6.19 & 27 \\ \text { Controle probleem } & 11.19 & 5.45 & 21\end{array}$

controle groep $\left.F(1,46)=6,24, M S_{\mathrm{e}}=44,44, p<0,05\right)$. Maar de veronderstelling dat her antal beschrijvende proposities in de recall van de stekelig voorval groep in vergelijking rot de controle groep ongeveer gelijk zou blijven moet op basis van de onderzocksresultaten verworpen worden. Het aantal beschrijvende proposities in de recall van de stekelig voorval groep is significant hoger dan van de controle groep $\left.F(1,46)=6,54, M S_{i}=41,53, p=<0,05\right)$. Blijkbaar leidt probleemanalyse in de experimentele groep in vergelijking tor de controle groep tor beter onthouden van beschrijvende en verklarende informarie in de tekst.

Verwach werd ook dat her aantal inferenties in de recall zou roenemen onder invloed van elaborarie op basis wan her probleem. Het aantal inferenties in de recall is namelijk een indicatie voor de mate van integratie van voorkennis met de nicuw geleerde kennis. Variantie analyse toonde echter geen significante verschillen aan tussen de rwe groepen wat betreft het aantal inferenties in de recall $P(1,46)=$ $\left.0,914, M S_{\mathrm{c}}=34,56, \mathrm{p}=0,34\right)$. De gemiddelden en standarddeviarics staan vermeld in Tabel 5.2 .

Blijkbaar leidt probleemanalyse niet tot een groter atntal inferenties in de recall direct na bestudering van de informatie in de studietekst.

\section{Discussie}

Het experimen dat in dir Hoofdstuk word bescheven werd ontworpen om na to gaan of de gevonden effecten uit experimenten in Hoofdstuk $3 \mathrm{cn} 4$ aok in ecor meer natuurlijke onderwijssituarie te vinden zijn. De resultaten wan dit onderzock laten zien dat probleemanalyse in een kleine grocp, woorafgande an de bestudering wan een relevante studierekst, hor leen van deze tekst vergemakkelijke en dau dus ook in een cologisch valide leeromgeving dere effecten te vinden zijn. De resultaren van deze studie komenovereen mer de effecren die Schmide (1982) heeft gevonden en mer de resultaten wan de experimenten wit Hoofdstuk 3 en 4 . Dir is consistent mer de elaboratic hypothese die verondersted dat problemanalyse leide cor een betere integratic van de nicuwe informatic in de bestande kennis en daarmee tot een betere toegankelijkheid van deze kennis. Dir zou verklaren warom meer informatic van de tekst word herinnerd. Het patroon wan de recall is echter anders dan werd verwacht. Er was geen interactie-effect tussen treatment en type 
proposives. Dit komt overen mer wat Schmidt (1982) constarende, namelijk dat problechanalyse ew algemeen facilierend effect heef.

Ook her ontbrekn van wershilken tussen experimentele en controle groep wat be weft het aandal inferentics is intrigerend. Van den Brock, Flercher en Risden (1993) gewen, op basis van cen modd voor onderzoek nat het oncstaan wan inferenties, cen aantal verklangen wor het wel of niec plaarsvinden wan inferenties in de reall. Zo conduderen zij dat de lengte van een sudietekst, de tijosduur voor bestudering van de sudierekst. de kenmerken wan de criceriumroets, de ard van de bak en het tidstip warop getoers word de mate van interenciele processen kan beinvloeden. In dit geval lijkr voonal de "inferential-reconstruction hypothese" en rol te spelen. Dere hypothese implicen dat relevante voorkemis reconstuctie van do te herinmeren informatie vergemakkelijk, doordar in ferenties worden gegenereend. Daarbij is gebleken dat hoe langer de periode is cussen het leren van een rekst en her zich herinneren daavan, des te sterker de invloed is van de vookennis. In dir onderzok werd de proefpersonen gevraagd zich de informatie wit do rekst te herinneren ditrect na de bestudering van de tekst. Op basis van deze byponthese zow verwach mogen worden dat de mate van inferenties in de recall wooral ma een zekere rijdsinterval acheraf zichrbar word. Dit zou mogelik verkaren watom er zo wcing inferencies in de recall arowezig zijn.

Verschillende hypothesen kunnen genoend worden woor de verklaring van de gevonden onderyokstesultaten. Alleroers is dat de motivatic hypothese. Deze hypothese kan verklaren wanom or in de groep dic het stekelig woorval analyserden meer geleed werd din in de controle groep. Door de probleemanalysewerd men zich meer bewust van de lemtes in kennis wat door meer intrinsicke mocivatie en dardoor lecrie en ondield men meer van de bestudeerde studierels. Her zou ook het ondreken van en interacric effect russen treament en type proposirie kunnen verklaren. Een wede mogelijke hypothese is de setectieve-aandacht hypothese. Deze hypothese verklatr de grotere effecten bij de experimentele groep wat horeft het zich herinneren van de rekst maar het gevonden paroon wan reall is hice niet consistent mes. "Ho verklater dege bypothese bijvoorbeeld niee watrom er mer beschijuende proposithes weden hernnerd. Tenslote is a de dabratie hypothese. Dore kin de grotere effecten van de groep dic "het stekelig woorwal" analyoude verklaten. Kor gezegd kom deze verkaring er op nee dat problecmanalyse lede rot con grotere integrare van de nietwe informatie in he bestande kennibestand, watrdoor er en grotere togankelijheid is van deze kennis, warardoor deze kennis beter herinued wordt. Het patroon van de recall en de mate van inlerontes in de recall zin moeilijker te werlaren.

Vonder onderack nate de effecen van probleemanlyse in een meer natumajke contex zal op en aunal punten anders ingerich moeten worden. Allereerst bevelen Van den Brock, Fetcher en Risten (1993) atn om in onderzock naar inferentics meer tijd te geven an procfpersonen voor her bestuderen van de 
studietekst. Daarnaast zijn zowel de inferenties direct na het lezen wan de tekst wan belang alswel inferenties na een rijdsinterval. Verder wordt er in de literatuur in roenemende mate op gewezen dat inferenties nader gespecificeerd moeten worden (Kinsch. 1993; Van den Broek, Fletcher, \& Risden, 1993). Tenslorte lijkt her wan belang om bij de free recall toers wat betrefr instructie meer aan te sluiten bij een taakstructuur dic ook terug te vinden is in probleemgestuurd leren. 

Hoofdstuk 6

\section{Probleemgestuurd leren: Cognitieve en metacognitieve processen tijdens probleemanalyse'}

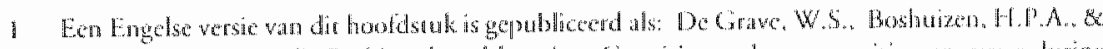
Schmide. H.C. (1996). Problem based learning: Gognime and meragnitive procenses daning

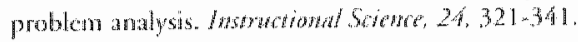




\section{Inleiding}

Ten gevolge van de cognitieve processen die probleemgestuurd leren word verondersteld te scimuleren neemt men aan dat deze vorm van leren een aantal voordelen heef bowen meer traditionele benaderingen van onderwijzen en leren. Schmidr (1983; 1993) benadrukt de effecten van probleemgestuurd leren op kennisacrivatie cn elaboratie. In een onderzoeksoverzicht presenteerden Norman en Schmidr (1992) empirische ondersteuning woor deze claim. Ondanks het veronderscelde belang van deze cognitieve en metacognitieve processen is er weinig bekend over wat er feitelijk gebeurt en hoe probleemgesturd leren in onderwijsgroepen haar posirieve effecten teweegbrengt. Er is wel enig onderzock gedaan naar de verbale interactie die plaats vindr in dergelijke groepen (bijw. Schmidt, Spay, \& De Grave, 1988). Toch is het inzicht in de aard van de verbale interactie en de dechame door studenten onvoldoende om de effecten van probleemgestuurd lcren te verklaren. Webb (1991; 1992) laat bijvoorbeeld in een overzicht van onderzok naar coöperatiefleren zien dar de minder verbaal actief deelnemende studenten in de onderwijsgroep evengoed kunnen leren in de onderwijsgroep als de mecr dominante groepsleden. Ze suggereert dat onderzoek naar de cognitieve en meracognicieve processen nodig is (zie ook Brown \& Palincsar, 1989; O'Donnell \& Dansereau, 1992).

Probleemanalyse speet cen centrale rol in probleengestuurd leren. Schmide (1993) veronderstelt dat het tenminste een viertal doelen dient. Allereerst zal her studenten helpen on zo veel mogelijk kennis die beschikbaar is te mobiliseren. Het activeren van voorkennis is belangrijk omdat dit het leerproces richting geeft en her begrijpen van nieuwe begrippen vergemakkelijkt. Verder helpt groepsdiscussie studenten om te elaboreren op hun kennis. De confrontatie met het probleem dar begrepen moer worden en de confrontatie met de verklaringen van andere studenten zal leiden tot een verrijking van de cognirieve structuren wan de dechemers. Ten derde de kennis die op dir punt reeds beschikbaar is, wordt afgestemd op de specificke context die wordr aangeboden, namelijk her aangeboden problem. Tenslone word verondersteld dat door de discussie de studenten zo berrokken worden bij de leerstof dar hun nieuwsgierigheid wordt opgeroepen, zodat $x$ in meer decail willen gatan uirzoeken hoe het probleem verklaard kan worden. Kennisactivatic en claboratie, discussie met andere studenten en de afstemming vin de kennis op het probleem zijn nier alleen een voorbereiding op individueel lerch, her is ook kenmerkend voor een meer coöperatieve vorm van leren die resulteer in ecn herstucturering van kennis of in conceptuele verandering. In andere kenuisdomeinen en in andere onderwijscontexten is angetoond dat conceptuele verandering gestinulcerd word door siruaries die leiden tor ontevredenheid met de bestrande kennistoestand. In probleemanalyse wordo de bestaande kennis ter discussic gesteld en geevalueerd, hergeen de herstructurering van die kennis zou 
moeren bevorderen. Volgens Brown en Palincsar (1989) is concepuele verandering meer waarschijnlijk wanneer men de eigen posinie moer werklaren, elaboreren of verdedigen ten opzichte van anderen dan ten opzichte van zichzelf: het gericht zijn op het geven van een verklaring scimulcert cen leerling om de kennis te integreren en te elaboreren op een nieuwe manier. Een van de belangrijkste variabelen die de voordelen van sociale leeromgevingen kan verklaren is conflicr in de groep. Hoewel sociaal conflict cen essenviele stimulans kan zijn benadrukken Brown en Palnesar (1989) dat kennisverandering meer her resultat is van co-elaborane en co-constuction op basis van een gedeeld cognirief conllict in plats van een social conflict.

Een typisch cognitief conflict, vooral in een onderwijssering, ontstaat doordar de bestaande kennis niet overeenkomt met nieuwe informarie (anomalic). Zo zullen bijvoorbeeld een knikker en een veer wanneer men ze regelijk van een hoogic van wee meter laat vallen, de grond niet op herzelfte moment berciken. Desondanks voorspele de wer van Newon dar dir zal gebeuren. Hoe is dir mogelijk Studenten kunnen in deze situatie op veel verschillende manieren rageren, die kan varièren van nier geloven tot een radicale verandering van gedachren. Chinn en Brewer (1993), die een overzicht hebben gegeven wan onderzoek nat de rol vin conflict in her stimuleren van conceptuele verandering, veronderstellen dat deze verschitlen veroorzakt worden door vier cognirieve kenmerken: De status wa de awomatie in de perceptie van de studenten, de kenmerken wan de woorkennis, de perceptie die studenten hebben van de validiteit en geloofunardigherd wan de nicuue thorit, en de leerstrategieën. Dezc aspecten bepalen of een cogniricf conflict wordt ervaren en of een cognitieve verandering plaatsvindt. War betreft de kenmerken van voorkennis die moet worden veranderd merken Chinn en Brewer op dat de verankering van voorkennis, de ontologische opvatringen, de kennistheoretische opvatringen en de achtergrondkennis kumnen resulteren in een sterke weerstand regen verandering. Verder is cen plausibele alternatieve theorie dic accurat is, een brede roepassing heef, consistent, eenwoudig, wruchtbaar on begripelijk is, makkelijker te accepteren dan een theorie die cén of meer van deze kwaliteiten niet heft. Ditzelfece is van toepassing op geloofwardige, niet ambigue in formatie dic aflomstig is uit meerdere bronnen. Deze informatie wordr genakkelijker atnvardr dan andere gegevens ook al is dexe strijdig met de oude voorkennis. "lenstotre heblen de verschillende leerstrategieën die men toepast bij de evaluatic van anomalieën verschillende effecten wat betreft conceptele verandering. Wannecr regenstrijdige informarie op een diepe manier verwertat worde dan bevordert dit cen dergelijke verandering. Zo n leerstrategie implicen mente processen zoals zorgvuldig aandacht besteden aan de tegenstrijdige informatic, proberen de alternaticve theorie te begrijpen, elaboreren van de relaties tussen her bewijs en de andere theoricion en nader in beschouwing nemen van alle bewijs. De specifieke combinatic van deze vier factoren bepaalt hoe studenten omgan met de strijdige informatie. Studen- 
ton kunnen dexe negeren. Ze kumnen deze informatie verwerpen. Ze kumnen de stridige informatie uirluiten. Ze kunnen de strijdge informarie voorlopig in beschouwing nemen. Ze kunnen ook de infomate herinerpreteren. Tenslote kunnen ze hun theoric marginal of meer radical veranderen.

Probleengestund leren kan worden opgewat als een onderwijs en leerstrategie die probeert cognirief conflict bij studenten op te roepen hergeen leid ror conceptuele werandering. Dit conflict on rstat wanneer de kennis van de individuele studenten. en het problem war zij an werken niet mer elkaar overenkomen. In feire is di cen axioma van problemgestuurd leren. Exn probleem moet zo ontworpen worden dater en discrepantie of tenminste en kloof is tussen de kennis van de student en her probleem. De manier watap studenten ongan met dic conflict zal grotendects voorkomen wit deze discrepancie. Alernatieve theoricenn worden niet angeboden door de docenten, matr worden geconstrueerd in de groepsdiscussie. gebaseerd op een combinatie en evaluatie van de kennis van alle groepsleden en larer geverifieend tijdens zelfrudie en rapportage. Wanner geen plausibete theorie kan worden geconstrueerd, zal geen conceptuele verandering kunnen plaarsinden. De andere twee factoren zullen warschijnlifk een minder belangrijke rol spelen. De geloofwardigheid van de regenstrijtige informatie zal hoog zijn wanner deze informatie geleverd wordt door her blokboek of de curom. De informarie die door de grocpleden zelf natr voren wordt gebrach zal verschillend worden beoordeeld. Tenslorte zijn de studenten getraind om op deze man ner te werken. De zevensprong garandeer een diepe benadoring van het probleem.

Het doel wan de stutie die in dir hooflstuk word gepresenteend is rweeledig. Her belangrijkste doel is te onderzocken of probleemgestuurd leren inderdad leido tot concepruele verandering. Daar conceptuele verandering zelf (niet de facroren die eroe leiden) ecn intra-individueel proces is, moer en methode ontworpen worden die gevolig is voor deze verschijnselen. In deze studie is gebruik gemaakr van een stimulated reall methode (gesuggereerd door Wobb. 1991). De hicruit resulrerende protocollen werden geanalyserd met behulp wan een zooming in technick, fic zich ecese richte op de meer macroscopische kenmerken wan de prorocollen en darna gevolgd wend door en meer microscopische analyse van de dymamasche aspecren van de protocollen. Tenslote werden de zeven manieren van ongang met do regenstrijige informate (zoals beschreven door Chinn en Brewer, 1993), varierend wa her negeren van de tegenstrijdige informarie rot cen raw dicale verandering van theorie, gebruike om cen prococol van een individuelo student op een meer gedeaillewd nivau te analyseren. Daabij werd gezoch nat sporen van concepruck verandering. Als gevolg van deze tweeledige doelstelling vin de studie heet dic hoofdsuk zowel ecn methodologisch als een theorerisch aspect. Deze worden afoonderijk behandeld. 


\section{Methode}

\section{Proelpersonen}

Een kleine onderwijsgroep werd gevormd uit vijf rweedejars studenten van de studie geneeskunde aan de Universiteit van Maastrich. Deze studenten waren goed ingewijd in de principes van probleemgestuurd leren. Zij hadden ongeveer twee far lang problemen geanalyseed in onderwijsgroepen die rwo keer per week bijeenkwamen.

\section{Materialen}

Het probleem (casus) die de studenten moesten analyseren was een casus uit het blok "Pijn". Dir blok is onderdeel van derde curriculumpar. De moeilijkheidsgraad van her probleem was hoog genoeg om de cognirieve processen van de sudenten re stimuleren. Aan de andere kant hadden zij ook voldoende voorkennis on het probleem te kunnen analyseren.

\section{Casus: Een pijnlijke ringvinger}

Marcus B is een 34 jarige bankwerker, die nog nooit zijn huisarts heeft bezocht. De laatste maanden echter heeft hij een aantal keren een voorbijgande "rode streep" aan zijn beide onderarmen opgemerkt, die ook licht pijnlijk was. Daarnaast doet zijn linker ringwinger erg pijn, vooral als het buiten koud is of wanneer hij mer koud metaal werkt. Deze vinger wordt dan ook lijkwit om via blauw en rood weer normaal te kleuren na enige tijd. De laatste week was de pijn in zijn winger echter zo hevig geworden dat hij besloot om nu toch maar eens zijn huisarts te raadplegen. De bedrijfarts had hem er wel al cens op gewezen, dat zijn vele roken (tot 2 pakjes per dag) zijn gezondheid op de lange duur wel eens kon schaden, maar dat was tenslotte toch een zorg voor later!

Deze casus gaat over een niet vaak woorkonende ziekre genamd "thromboangitis obliterans'. Deze stoornis worde gekenmerkt door een onsteking en afshuiting wan de kleine en middelgrote slagaders en aders in de handen, onderarmen, vocten en benen. Deze afwijking ontwikkel zich vooral bij mannen beneden de lefrijd van 40 jaar, vooral bij mensen die komen uit Azië en Oost-Europa. De orraak van thromboangiitis obliterans is nier bekend. Er is echter en bepaalde relatie met roken. Trombose van de vaten is warschijnlijk een belingrijke gebeurenis die leid tor een intense ontstekingsreactic. Deze ontsteking heefe fibrose rond de bloedvaten tot gevolg, die leide tot abstrucric van de bloedroevoer. De meest algemene symptomen zijn kramp in armen of benen. Een ander algemeen symptoom is tij- 
delik zunstoftekont (afname van bloedtoevoer naar een weefsel dat resulteert in gebrek aan zuurstof) van de vingers of tenen na her blootgesteld zijn aan kou. Dit manifesteer zich als pijn en de beschreven kleurveranderingen (genaand Reynauds" verschijnselen). Een clede symproom is thromboplebitis in de oppervlakkige aderen. In Figuur 6.1 is aangegeven hoe de kennis over thromboangnitis obliterans gerelatererd is an de informatie in de casus.

\section{Procedure}

De onderwijsgroep analyseerde her problecm gedurende 20 minuten. De discussie werd voorgezeten door een wan de studenten. De groep zat in een halve cirkel. De inceracre in de groep werd in een professionele video studio op videoband opgenomen. De technische staf bevond zich in een afzonderlijke ruimte. De proefpersonen in de onderwijsgroep werden geinstrueerd om de casus zo te behandelen als zij normal ook zouden doen. Er werd hen medegedecld dat de video-opnamen ongeveer 20 minuten zouden duren, mat dat zij niet op de tijd hoefden te letten. Ze zouden worden gewaarschuwd wanneer zij de discussie moesten stoppen. Derde en vierde jaars geneeskunde studenten ( 5 in totaal) traden op als interviewers in de stimulated recall sessie. Deze studenten volgden een speciale training voor deze taak. De interviewers waren bekend met en hadden ook de relevante achtergrond kennis die benodigd was voor de casus die werd geanalyseerd. De interviewers werden, voordat de problecmanalyse werd uitgevoerd, toegewezen aan de individuele leden van de onderwijsgroep. Tijdens de probleemanalyse konden zij de groep observeren (vooral de student die zij hadden toegewezen gekregen) via monitoren in de videostudio.

Direcr nadat de sessie was afgelopen werden van de mastertape vijf identieke kopiën mer rijdcode gemaakt. Onderussen waren de interviewers en de proefpersonen nat nabijgelegen kleine ruimtes gegaan voor de stimulated recall. In dere ruimtes waren video afspeclapparatuur en audiocasserte recorders geplatst. De inrerviewer introduceerde hem/haar zelf en legde de stimulated recall procedure uit. Na twe mimuten arriveerden de videobanden in de recall ruintes en begon de reall procedure. De studenten werd gevrangd alles wat zij zich konden herinneren van her denkproces rijdens de discussie te verbaliseren. De videoband werd afgespeeld on hen bij dit herinneren te helpen. Hke keer dat een gebeurtenis de student herinnerde an iets waarover zij had nagedachr rijdens de discussie werd de vidcoband gestopt. Dit kon door de student of door de incerviewer worden gedaan. De talk van de interviewer was om de proefpersoon te stimuleren tot het verbaliseren van het denkproces rijdens de recall siruatie. De scimulated recall sessie werd opgenomen op audiocassetteband. Nadat zij hier mee klat waren werden de proefpersonen kore geinterviewd over hun crvaringen tijdens groepswerk en stimulated tecall. 


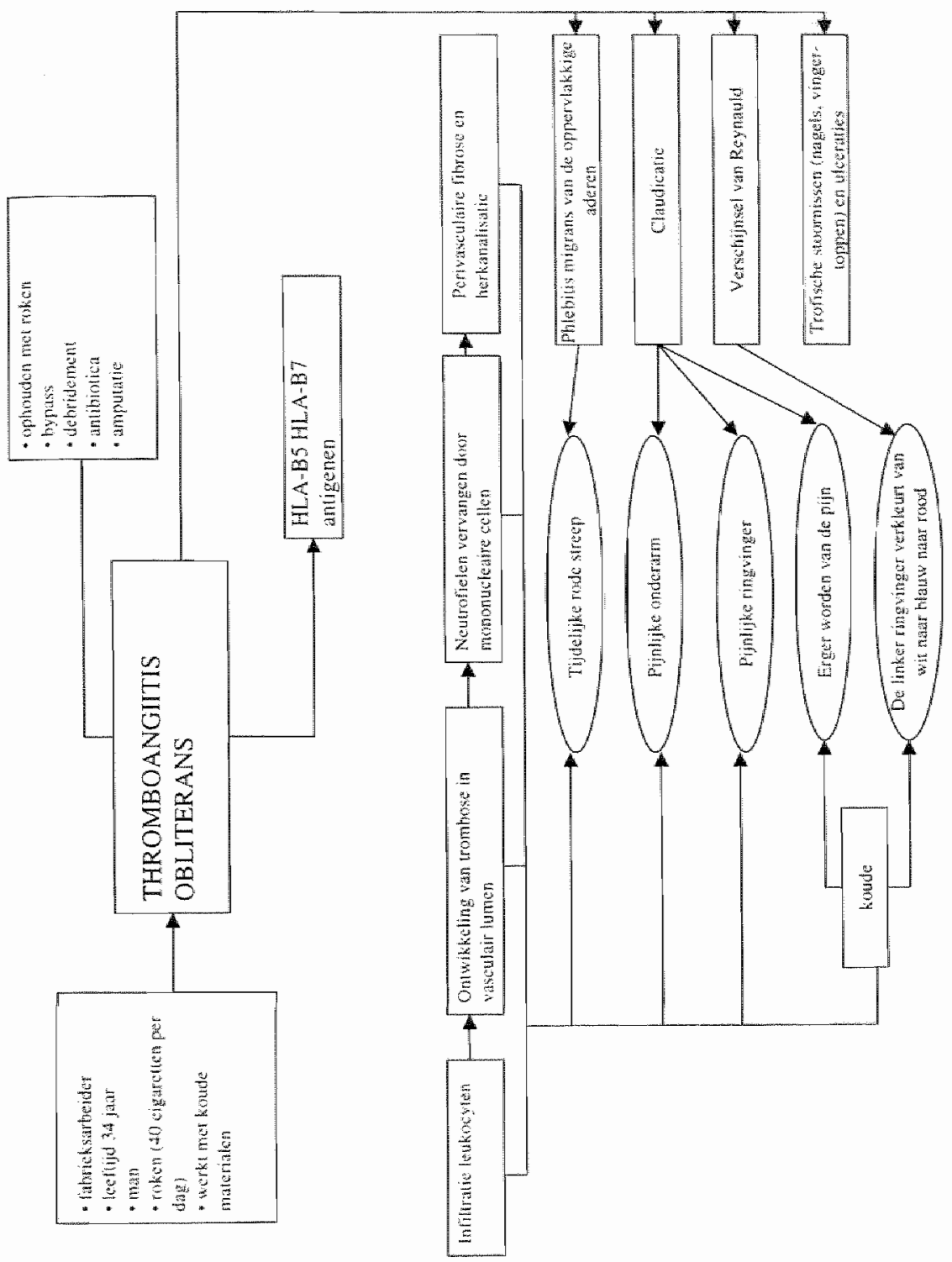

Figuur 6.1. Inhoudsstructuur van de casus: Een pinilike ringuinger. 


\section{Analyse}

Van de vidoband van de onderwijgroepen van de stimulated recall van de wer grocpsteden werd cen letrerlijk cranscripr met tijdcode gemaakr. Door problemen met de appanaur kon geen protocol worden gemake van de gesprekleider. De resulkerende protocollen werden opgededd in de keinst mogelike betekeniswolle enheden. Voor de classificatic wan deze wheden werd gebruik gemaakr wan een methode dic ourspronkelik ontworpen was door Hassebrock en Prictula (1992) voor de codering van diagnostisch redemeren. De oorspronkelijke methode was bedolld voor indiwidued diagnostisch redeneren. Daarom moest hij worden uitgebreid met een an al categorieén die betreking hebben op de sicuarie waaringedeeld diagnostisch redeneren tijdens problemanalyse in een onderwijsgroep platsvind. Om het sociale aspec daarin op te nemen werd de categorie proces niveat, mer twec subcaregorieën, eran roegevoegd. Verder werden sommige categoriecr zoals thcoric-cvaluatic en meraredeneren vereenvoudigd. Gegevens explorateon -interpretatie werden gecombincerd in één categorie.

Tabel 6.1. Codeer systeem voor protocollen wan zowel de verbale interactie als de stimulated recall ijdens probleemanalyse.

Proces Niveau

1.1 procedure

1.2 samenwerking
Taek Noveau

2.1 exploratie van gegewens probleem definitie; verwizing naar de infiomatie in de casuls: identificatie, structurering, intergratie en inttële interpretatie of informatie; signaleren van ontbrekende gegewens

2.2 theorievorming: causad redeneren: hypotheses; associaties specificaties: generalisaties.

2.3 theorie-evaluatie: bevestigende evaluatie; niet-bewestigende evaluatie; evaluatie over zekerheid

2.4 metaredeneren:

reflecties op voorkenmis; reflecties op het leerproces: reflecties op strategie wan denken.
Niet-takk Niveau

3.1 irrelevant 


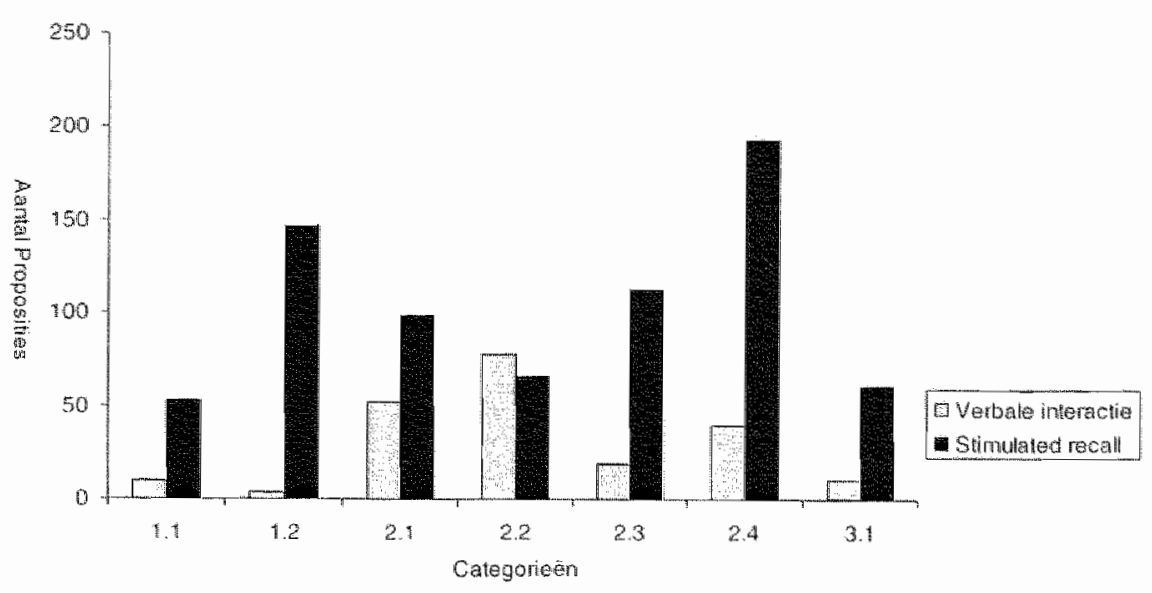

Figuur 6.2. Analyse van de verbale interactie en de stimulated recall. Frequenties wan propositie typen.

Analyse van de protocollen werd uitgevoerd door twee onderzoeksassistenten in een consensus procedure. Een voorbeeld van zo'n protocol analyse van een stimulated reall protocol wordt in onderstaande gegeven (excerpr van student $A$ ): Ja, daar dacht ikal aan het roken (code 2.1)/ Ja bloedvaten en roken kunnen er iets mee te maken hebben (code 2.2)/ wee pakjes per dag is nogal veel (codc 2.1 )/ $\mathrm{Her}$ werd in de casus op zo'n manier vermeld dar her er iets mee te maken heef (code 2.1)/ lk vroeg me af hoelang dat al duurt (code 2.1)/ Hij is sleches 34 (code 2.1)/ en hoe lang geleden zei die huisarts dar (code 2.1) Maar on daarop door te gaan leek mij nier zo relewant (code 1.1). (rijd: 1.52 )

\section{Resultaten}

In Figur 6.2 zijn de frequenties van de verschillende onderscheiden ategoricën zinvolle eenheden wergegeven voor zowel verbale interactic als stimulared reall.

Deze grafick laat zien dat de verbale interactic en stimulared recal protocollen dezelfde categoriën van cognitieve processen bevaten, matar in verschillende verhoudingen. Dir geldt vooral voor groepsprocedure (1.1), grocpssanenwerking (1.2), theorie-evaluatie $(2.3)$ en metaredeneren (2.4). Blijkbar neigen studenten erroe deze cognitieve processen nier explicier we maken, woomal wanncer zij de bijdrage van andere groepsleden waarderen en wanneer zij reflecteren op hun eigen voorken is en hun leorproces. De verbale interacte roont slechts de top van de ijsberg wan deze verschijnselen. De stimulated recall protocollen zijn nodig om meen inzicht te krijgen in de processen en vorwaarden woor concepruele verandering. 
Slechts en categorie, theorievorming, is meer prominent aanwezig in de verbale interactic dan in de stimulated recall; weinig addirionele informatie kan worden gevonden in de stimulared recall protocollen. Dir berekent dar de inhoud van de verbale interactie cen goede indruk geeft van het causale redeneren dat gaande is. In dit experiment werd echrer een redelijk kleine groep gebruikt. Als de groep groter was geweest, zou de verhouding van theorievorming in de verbale interactie en theorievoming in de stimulated recall waarschijnlijk minder uitgesproken zijn geweest, daar er slechrs én student tegelijkertijd kan praten, terwijl elk zijn eigen idecen ton overwegingen kan hebben. Exploratie van gegevens is ook een duidelijk aanwezige caregorie in de verbale interactic.

Het is inreressant om te zien dat her denken over procedures en over samenwerking in de groep een belangrijk onderdeel is van de cognirieve processen van de groepsleden die zij eerder woor zich houden. Verder is het voor studenten moeilijk om constant taakgericht bezig te zijn. Vooral de stimulated recall protocollen tonen aan hoe studenten aan het "dagdromen" kunnen zijn, zoals het volgende excerpt van student $D$ aantoont.

Ik probeer de discussic te volgen, maar het is moeilijk voor me om me te concentreren. Ik schrijf met mijn linkerhand en ik teken een bloem. Ik denk aan een meisje dar alrijd bloemen rekende. Dan kijk ik naar het bord om weer aan de discussic mee te doen. (rijd: 19.00).

Deze analyse van de protocollen als een geheel in categorieżn levert slechrs een statisch beeld op van de cognitieve en metacognitieve processen tijdens probleemanalyse. De tijdcodes geven de mogelijkheid om ook de gedachtenstroom tijdens de twintig minuten te analyseren. Hier presenteren we de temporele analyse van de categorie 'theorievorming'. Deze categorie werd uitgekozen omdat het geven van verklaringen in theorieèn over coöperatief leren (Webb, 1991,1992) centraal stat en suggereer dat variabelen gerelateerd aan het geven van verklaringen (op ecn verbaal niveau) erg belangrijk zijn voor leereffecten. Figuur 6.2 laat zien dat deze categoric he meest prominent anwezig is in de verbale interactie. Theorievorming kan worden gestimuleerd of belemmerd in cen groepsproces. Tijdens de discussic kan de frequentie van theorievorming roenemen of afnemen. Figutur 6.3 roont dit patroon.

Wat opvalt is dar de twee patronen voor interactie en stimulaced recall nogal overeenkomen. Dere grafiek wordt beter te begrijpen wanneer de inhoud van de discussie tijdens de 20 minuten wordt onderzocht op basis van het theoretisch kader van Chimn en Brewer (1993). 


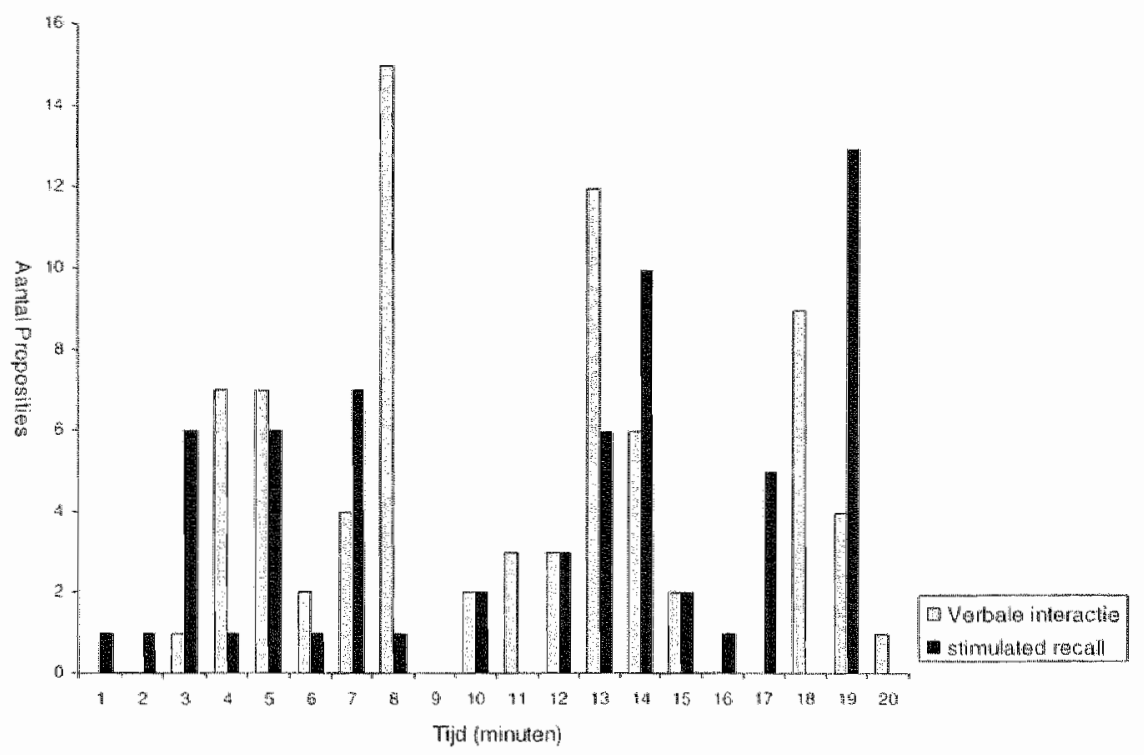

Figuur 6.3. Frequentie van theorievorming in de verbale interactie en de stimulated recall per tijdseenheid (minut).

Tijdens de cerste wee minuten definieerde de groep de problemen die moesten worden geanalyseerd. Vier problemen werden gëdentificerd: 1 . Wat is de oorzak van de rode streep? 2. Warrom is die linker ringvinger pijnlijk en koud door koud materiaal of koud weer? 3 . Hoe zijn de kleuren te verklaren? 4. Wat is de relatie met her roken van sigaretren?

Van de derde tor de achiste minuut genereerde de groep verklaringen voor her problecm van de rode streep over de onderam. De groepsteden consirucerden. verschillende theoricën on dit probleem fo verklanen. Allereerst was at ale theoric over bloedvergifriging (sepsis); verwolgens werd er cen theorie over lymbangitis nar woren gebracht, en renslote, was er een theoric over stenose. In de loop vande discussie ontstond er een overeenstemming aver stenose als cen verklaring voor de problemen van de patient.

Vanaf de achtste minuut, begon de grocp te werken aan het twede probleem (de relatic russen piin en kou). Om deze symptomen te verklaren werkten aij stonose verder uit, zij spraken voonal over de gecombinecrde effecten van stenose en vasoconstrictie op de bloedvaten. Zij genereerden ook verklaringen voor de verschillende kleuren (problecm 3). Op dir momene kwamen de studenten mer veel verklaringen (zie Figuur 6.3). Vanaf de negende tot de derricnde minutu dachten zij na over de kleuren en keeden ook terug naar de rode streep. Nu ontstond het idec van een ontstekingsreacrie en de relatie tussen ontsteking en stenose. "Twe van de 
studenten kecrden terug naar het idee van sepsis. In deze fase was er enige verwarring en genereerden zij nier zoveel nieuwe idecèn.

Vanaf de dertiende minuut vervolgde de groep met her verklaren van de kleurveranderingen en relatectden dit aan roken en stenose door het begrip zuurstofgebrek. In de veertiende minuut probeerden zij meer specifiek te zijn over de relarie tussen roken en stenose. Na het bedenken van idecën hierover constateerden zij dat zij leemtes in hun kennis hadden en ook op dit moment was er geen echre vooruitgang in her denken. Zo dachten de studenten aan de ringvinger en hadden enige associaties met achrergrond kennis, maar bedacheen nier echt verklaringen voor de symptomen. In de achtriende minuut keerden zij terug naar de relarie cussen de linker ringwinger en de rode streep. In de negentiende minuur besteedden zij kort andacht an de mogelijke invlocd van werkomstandigheden van een fabricksabeider. In de laarste minuut vatte de gesprekleider de discussie samen en beëindigde de groepsbijecnkomst.

Tijdens deze discussie makakien de studenten een proces van conceptuele verandering door. Dit word geilllustreerd door de excerpten van de stimulared recall prowoollen. Eén student was erg expliciet in haar conceptuele verandering. We zullen daarom haar stimulared recall gebruiken voor een meer gederailleerde analyse van de facroren die conceptuele verandering beinvloeden. Zo nu en dan echter zullen we daar de excerpien van de stimulated recalls van andere studenten aan toe voegen. Deze excerpten beslaan de periode die loopt van de derde tor de achtste minuut, cen periode warin theorieén worden gegenereerd on sommige van de gegevens re verklaren en warin de studenten proberen her juiste spoor te vinden dat verder uirgewerkt moet worden.

De inhoud van de verbale interactie en de stimulated recall zijn beide naast elkar afgedrukt om de vergelijking tussen beide mogelijk te maken. Soms worden deze excerpten onderbroken door commentaar om de relatie tussen het excerpr en thet theoretisch kader wan Chin en Brewer duidelijk te maken. 
Begin: 2.15

Verbale interartie in de grop

E Probleemsteling een: Wat is die rode streep?

C: Misschien een arterte.

B: Ja, we hebben ooit eens iets gehad over bloedvergiftiging.

E: Lymfangitis.

B: Ja een of andere ontsteking.

A. Ja. wat was dat nou?

E. Een ontstekting in de lymfe toch? Een ontstekingsreactie die doorgaat naar de lymfe Lymfgangitis, en dan krijg je een rode streep.

\begin{abstract}
Stimulatedrecall van student $A$
la toen ging het over die bloedvergltiging.

En toen begon lk eigenlik nog meer te derken wat was dat woord nou? En hoe zat het precies? I........ J k zat zels te denken aan de literatuur die ik ver be studeerd had, maan k wist het niet meer. Dat was een chirurgieboek geloof thever wondgenezing. IK wist dat we het gehad hadden En dan wil ik het weten Ik herinnerde me die casus, die rode streep en die roestige spijker en dat hij een hek awn het timmeren was en dan krijg je eefontsteking dis helemad doortrok door die arm. Baar zit ik de hele tijd over door te denken.

Ja daar had ik zoiets wan "Dat is het nie:". lk wist dat lymfangitis... Dat klonk niet echt. Nee ik zat te zoeken nat het woord sepsis, dan weet ledereen wat ik bedoel. van die lynife, dat geloofde lk wel, in leder gewal dat ze er lets mee te naken hadden. Maar zijn werhal kwam niet echt oventuigend over.
\end{abstract}

Einde: 3.02

Dit excerpt latat de invloed zien van de factor achrergrondkennis op de manier waarop student A reageede op de gegevens. De casus decd hat herinneren aan een eerdere casus over sepsis, hoewel ze dat woord nier kon vinden. Haar ractic op het verhaal van de lymfe is illustratief yoor de vorm van voorlopig in beschouwing nemen van gegevens die een anomalie vormen. De ideecn over lymfangitis waren tegenstrijdig met haar opvatringen. Ze anvardde deze informatic gedeeltelijk, maar verklaarde de gegevens nog niet. Door dit voorlopig mee in beschouwing te nemen, werd de oorspronkelijke theorie niet beinvloed. Maar wanneer deze informatie meegenomen wordt, dan betekent dit dat deze theorie later vorder uigewerkt wordt, zodat her deze gegevens kan verklaren. Later in de verbale interacric en in de stimulated recall wan deze student wend geprobeerd de theorie verder uit te werken. 
Begin: 3.19

Verbale interacte in de groen

D. Mar die rode streep, is die in de lengte wan z'n arm?

$C$ : ja ik denk her wel.

A. Madr de intormatle in de casus is an. ders.

B: Een worbigande rode streep... (leest hardop woor uit de (asus).

D. Ja het linkt me egenligk wellogisch maar het stalt er niet zo in de casus.

A. Hoe heette dat ook alweer, die bloed. vergifinging?

A. We hebben het owit eens in een blok gehad maar dat ging toen over een ontsteking ... vorig jaar? Met die spijker en dat timmereft en 20 .

C: Oh ja

A: Hij kreeg toen een ontsteking adan $z$ 'n dumen en dat trok toen helemal rood door

82

C: Maar dat was toen veel acuter.

A: Ja.

$C:$ In de loop wan manden.

A. Ja, in cen paar maanden.

Sumblated recall wan siudent A

Ja toen dacht ik dat klopt net helemaal, maar het blew toch wel hangen. Het is wel het punt dar ik ga twiffelen. Ja maar he: was riet hetzelfde. die rode streep wel allieen is het anders ontstaan maar hoe wistan we niet. Dat het in een paar maanden ontstean was en dat andere was heel acuut, dus kan het niet helemal hetzelde zinn.

\section{Linde: 3.50}

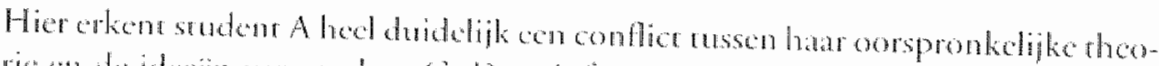

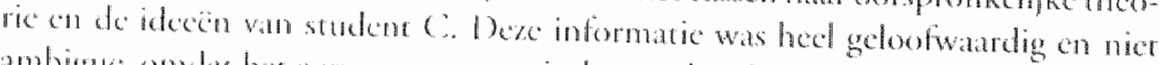

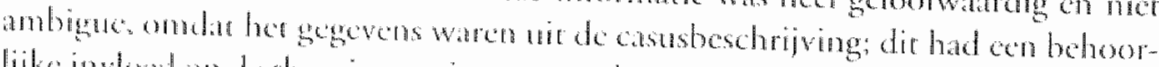

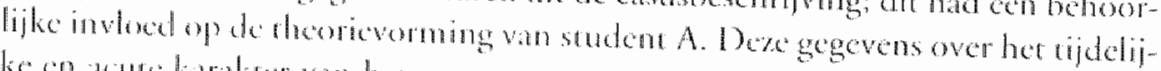

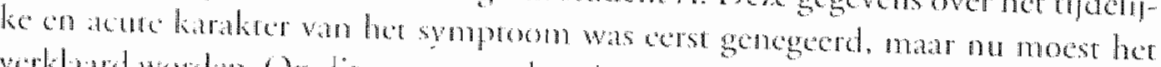

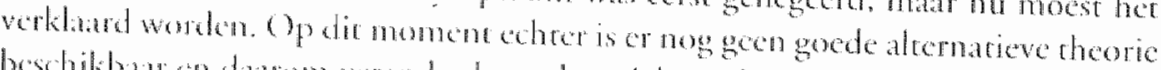

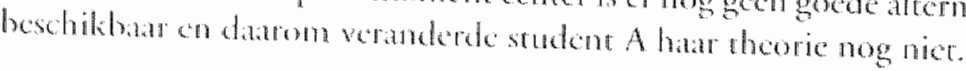


Werbale interacte in de groep

Stimulated recall van student $A$

C. Kan het geen vernauwing van cen bloedvat zijn? Omdat die ook zo heel veel rookt en als het koud word dan wordt thet bloedwat natuurlink nog nauwer.

Q: Wijst dat rode niet op een ontstekingsreactie? Bil een vernauwing zal het juist wegtrekken. Ja, ik denk dat je dan geen rode streep krijgt.

C: Ja.

A: Ia.

C: la misschien een ophoping van stoffen of 20 , ik weet het niet hoor.
Stimulated recall van student $\mathrm{A}$

Ja, ben was k het net sudent D eans. Een wernauwing, dat geeft geen rode streep. Itk had eigenijk eerst zoiets van nee dankan toch niet hater dacht $\mathrm{kk}$ dat het toch wel koin. Dat roken heeft een duidelijk verband ermee. th was nu dit aan het opsthrijuen: vernauwing van het bloedvat, de roodheid die van een ontsteking kwam. Wooral die lymfe, dat vergeet ik dadeligk en dat heeft er toch well mee te maken; en die bloedvat vernatwing daar zouden we toch wel op terug komen.

Einde: 4.22

Student C introduceerde een alternatieve theorie, namelijk stenose. Student D confronteerde student $\mathrm{C}$ met regenstrijdige gegevens en bevestigde daamee de theorie van student A. De tegenstrijdige informatie werd opgevat als geloofwardig en student $A$ begon al te twijfelen. Dat zij deze gegevens accepteede werd angetoond door wat ze opschreef.

Begin 4.22

Verbale interactie in de groep

A. Waarom alleen aan $z^{\prime} n$ onderarmen?

B: Misschien krijgt hij het nog aian $z^{\prime \prime} n$ benen.

E: Hij heef het trouwens aan beide onderarmen.

A. Ja aan beide onderamen.

A. Waarom in godsnam alleen aan $z$ in onderarmen?

$[\ldots \ldots \ldots \ldots \ldots \ldots . . . . . . .$.

\section{Stimulated recall wan student $\mathbb{A}$}

Ja, dat snapte ik niet. Waarom alleen $z^{\prime} n$ onderarmen. Als hij het aan $z^{*} n$ benen had dan zou dit in de casus staan. lemand zegt:

"Misschien heeft rij het ook aan z"n benen madr zie je het niet omdat hij een broek. aan theeft". Toen dacht $i k$, ja maar het is wel pijnlijk an dan zou hij dat voelen en ook als hij zich "s avonds unt zou kleden dan zou hij thet ook zien, maar dat leek me niet echt wan belang. Het moet iets met die onderam te maken hebben, dat was geen toeval. [...........] 


\section{Verbale interate in de groep}

C. Zouhet niks a maken hebben met dat roken, ik bedoel twee pakjes per dag heeft ous duidelik invioed op de bloedvaten.

C. Misschien een beetie een raar voorbeeld, mar de vader van een vriendin van mil is ook op een gegever moment gedotterd, ondat bij hen ook twee vingers helemad koud warem. Ze hebben frem toen gedotterd, ondat $z$ holodvaten helemaal dicht zaten.

D. Waar hebben ze 'n gedotterd?

C: lin z'm bowenarm twijst aant.

D: Duseen wernauwing var een bioedwat.

A. Eenvernauwing of ean propje.

B: Stenose

D. la dat is een verratiowing.

B: Mar dan kijg je toch geen rode streep?

A: Nee, dat snap ik ook nei helemaal, die rode streep. Dat die vingers rood worden okay.

B: Het feit dat die wingers kowd worden en licht pinliak wit ik ook nog wel aannemen. E: Die kleuren wan die winger kan je daardoor ook verklaren. Ais er geen bloed doorheen.

A: Maar waarom alleen in 2 'r linker ringvinger? Hii heef 't aan beide onderarmen dus zou je op z'n minst links en rechts werwathten.

\section{Stimulated recall van student $\mathrm{A}$}

Ik geloofde de vernauwing niet helemal. majr het moest er wel mee te maken hebben. Ik geloofde niet dat die rode streep door die vernauwing kwam. $k$ had zolets yan niet tra sriel zifn met die vernawwing lk was er niet helemal tegen. Vooral toen ze dat verhal wan die vader van die viendin vertelde. Toen dach ik $_{k}$ 'ja het zal dan wel war zin'. Het was wel een plausibel verhad, maar je kan er niet alles mee verklaren.

k zit de hele tijo alan mijn vingers $k$ wil duidellk maken wan hoe za dat nou. Ik zat de hele tijo te denken aan de linker vinger Toen zei zi: "War is hil dan gedotterd". "Ja, in de bovenarmen". Maar dit ziln onderarmen! lets dat ik zeker goed zal bestuderen: Waarom die onderamen?

Fincte: 6.00

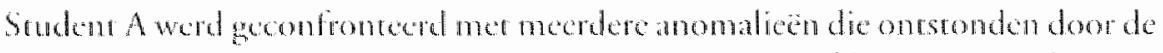

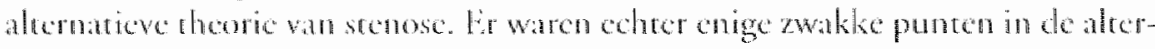

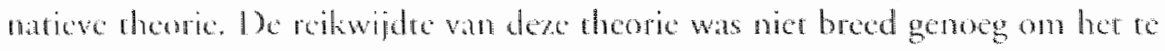

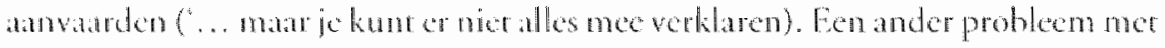

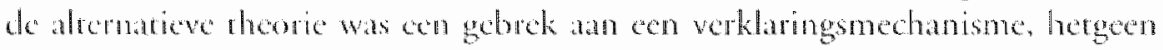
cen essenticel onderded is van cen plausibele altematieve rheorie. Sudent $A$ aan-

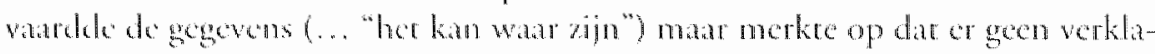
ring was vore het mechabisme. In her volgende ded van het protocol wan de stimulated rocall is dir zocken mar cen mechanisme erg dudelijk. 
Verbale interactie in de groep

C: Zullen we verder gaan?

E: Jadus.

C. Maar die rode kleur kan dai niet komen door die wermauwing? Ja, weet ik veel Misschien stoffen die achter blipen of 20. waardoor je een bepaalde reachie krijgt en waardoor die afvalstoften niel genoeg afgevoerd worden, of zoiets.

A: Ja maai dan zit je wel met die lymte?

Dan krijg je wel het verhaal rond. Afvalstof. fen die blijven zitten.

C: Ja okay, mar welke nam geef je eraan?

B: Ja, maar wat voor afvaistoffen?

A: Ja, ik wind het ook niet echt aannemeiijk.

C: Het is ook maar een brainstorm

\section{Stimulated recall wan student $A$}

Hier zat k ower na te denken. Dat wond ik well een mooi verhad die afwalstoffen en hoe dat werkt. Toen zag ik die vernauwing ook wel zitten. Toen paste het cen beetje. Het was nog niet allemalal duidelik. maar het was allemaal redelijk plausibel.

Die afvalstoffen, maar wat voor afvalstoffen. Het speelde wel. Het was niet echt aannemelijk, maar aan de andere kant wel Eigenilik begint dat ook te overheesen, zo van dat klopt wel. Maar toen studient $B$ zei: Welke afvalstoffen?" Ja, dat weet ik ook niet. Ik was ook niet echt overtuignd, ik zit er echt een beetje tussenin. Maar dat had iedereen wel.

Einde: 7.23

Dit excerpt illustreert een conceptuele verandering in student A (" dit begint de andere ideeën te overheersen"). De alternatieve theorie werd plausibel toen in het laatste deel van het excerpt een verklaring werd gegeven voor de afvalprodukten en het mechanisme hierachter. Student A had ook de indruk dat er een soort groepstheorie werd onrwikkeld. Deze indruk werd ondersteund door de stimulared recall van student $D$.

Verbale interactic in de groep

Stimulated recall van student $D$ ongeveer op dezelfde tijd

Ik dacht dat wê het allenaal redelijk duidèlijk hadden. Toen we begonnen rnet de casus dacht ik dat er geen vooruitgang zou zijn. Nu heb ik het idee dat we aardig wat wooruitgang hebben gemaakt.

Een ander kenmerk van de kwaliteir van de al ternatieve theoric is de vruchrbarheid ervan. Met andere woorden, wanneer deze nieuwe verklaringen kan genereren voor andere gegevens. In de prorocollen wan de studenten werd dit evident, roen zij begonnen hat wolgende probleem te werklaren en zij deze theoric gethruilkren en werder uirwerkten. Figuur 6.3 lat zicn dar de alternaticve theoric inderdand 
vruchboar was in de zin van her genereren van nieuwe idecën (bijv. in de 8ste minutur).

Het gebruik van deze theorie en de verdere wirwerking ervan kan worden gë̈dentificcerd in het protocol van de verbale interactie.

Verbale interacte in de groep lachisteminuty stimulated recall

D: k denk toch dat het bloedvat afgekneld

is door een plaque of zoiets of gewoon

rauwer is geworden. Bij koud weer zullen

de vaten zich vernawwen, dus dan word

doorbloeding gewoon nog weer minder. Je

kringt dan misschen een complete afslu-

ting van die ringvinger. Ja, waarom alleen

die rngunger, dat weet ik ook niet. Maar

er is een afsluting en dan wordt het wit.

C: da, en het kan dan ook best pinnilk zijn

door alle alvalstoffen. In ieder geval is er

geen goede doorbloeding.

D: De afvalstoffen worden niet wegge-

voerd en dan krijg je mischien een ont-

stekingsreactie, wardoor die rodle kleur.

Dit deel van de probleemanalyse laat duidelijk de verschillende cognitieve en metacognitieve processen zien. Figutur 6.4 en 6.5 vatten deze resultaten samen. Deze grafieken samen, suggereren dat veel niet-expliciet metaredeneren wooraf gaat an een toename in expliciete theorievorming.

\section{Discussie}

Het doel van dit onderzock was tweeërlei, te onderzoeken of probleemgestuurd leren inderdad leidt tor conceptuele verandering en om een methode te oncwikkelen die deze verschijnselen in beeld kan brengen.

Wat betreft het methodologische doel van dit onderzock, suggereren de resultaten yan deze studie dar de combinatie van een analyse van de verbale interacrie en van de srimulated recall protocollen behulpzaam kunnen zijn bij het onderzoek van individuele cognitieve processen rijdens probleemgestuurd leren in de kleine groep. Er zijn verschillende aspecren aan deze methode die de validiteit ervan ondersteunen. Allereerst hadiden de studenten zelf de indruk dat her op video opnemen van de probleemanalyse de discussie nier beinvloedde. 


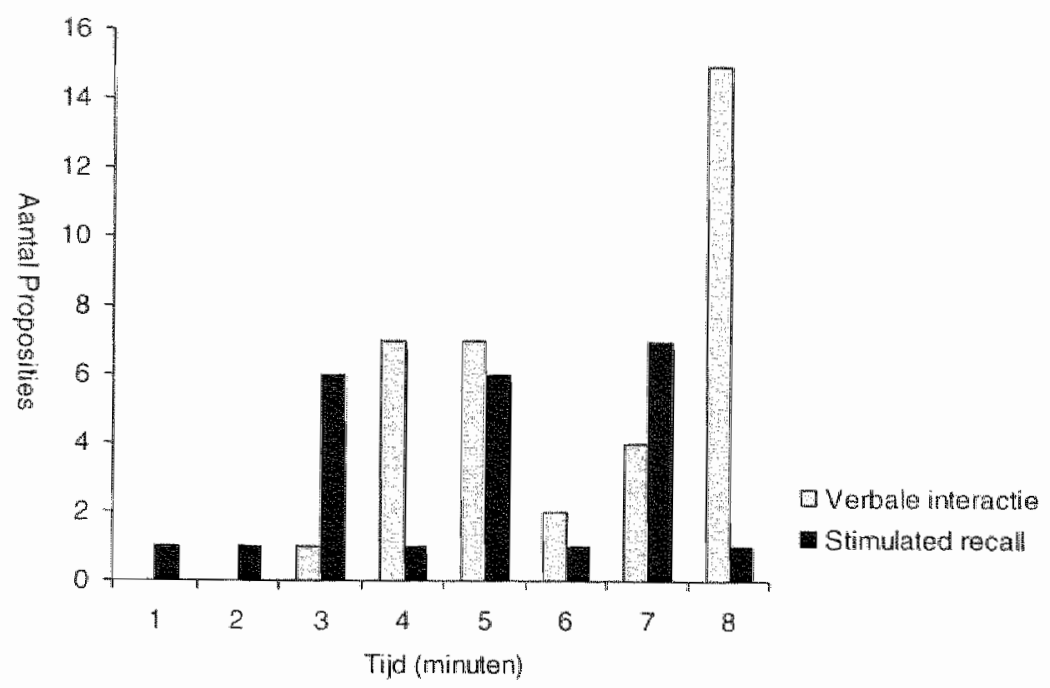

Figuur 6.4. Het proces van theorievorming gedurende de eerste ach minuten.

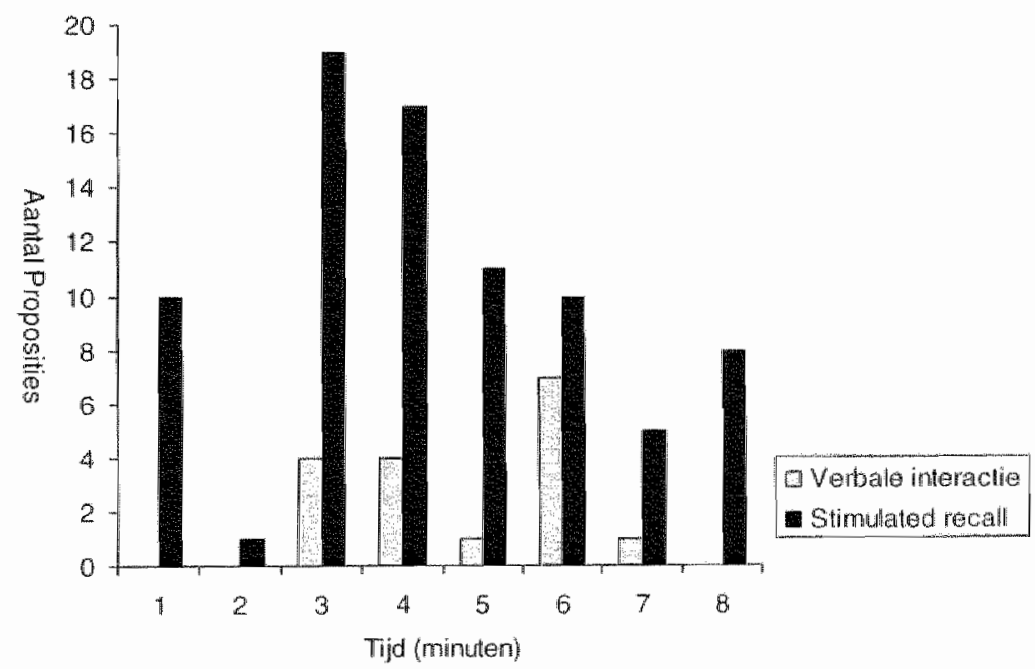

Figuur 6.5. Het proces van metaredeneren gedurende de eerste ach minuten.

Scudent C: "Eerst dacht ik dat het nogal een kunstmarige situatic zou zijn voor te brainstomen, maar ik vond her niet verschillen mer hoe het normaal verloopt in de onderwijsgroep".

Student D: "Ik was goed geconcentreerd bezig, ik had nier her idee: Oh daat is cen video, helemaal niet". 
Ook het feit dat de srimulated recall direct uitgevoerd werd na de problemanalyse maake dai de proefpersonen nog serk betrokken waren bij her cognitieve proces van de problemanalyse.

Student C: "Ik was verrast wat je nog weet over war je hebe gedache. Eerst had ik daar enige twijfels over, maar je kunt het allemaal herinneren".

Een ander opvallend kenmerk van dexe methode is dat de verbale interacrie, warop studenten gevraagd worde te reageren, kenmerken heefr van een hardop denk protocol. De sociale interactie situatie legt zekere beperkingen op an die interactie: niet icdereen kan op hetzelfde moment zijn gedachten uiten en sommige zaken kunnen beter niet explicier gemaakt worden. In de daaropvolgende stimulated recall sessie worden de studenten aangemoedigd om deze leemtes in te vullen.

Een vierde kenmerk van deze methode, die suggereern dat deze protocollen valide gegevens opleveren over de cognitieve processen, is de overeenstemming tussen de verbale interacticen de scimulated recall protocollen van de individuele studenten, en vooral ber feit dat zekere intra-individuele verschijnselen (metaredeneren) wooraf gaan aan andere verschijnselen in de verbale interacrie (theorievorming). Een voorbeeld van dir effect wordt gevonden in de vergelijking van Figuur 6.4 en 6.5 .

In onderzock naar het denken van de leck racht (Yinger, 1986), waar stimulated recall vaak is gebruikt, werden verschillende problemen ervaren met deze merhode, bijvoorbeeld het frequent gebruik van generalisaties en rechtwaardiging door proefpersonen, die nier direc gerelateerd waren aan de feirelijk situatie. In de protocollen van de proefpersonen kwamen weinig generalisaties voor en als dit wel het geval was, dan waren zij nauw gerelateerd aan her denkproces. Her volgende excerpt levert een voorbeeld.

Student B: "Toen dach ik, er worden valk dingen in een casus genoemd, die er niets mee te maken hebben en die de groep vaak op het verkeerde spoor brengen. Dat kan hier in deze casus het geval zijn" (rijd: 15.05).

Voor zover we weten, is deze studie de eerste geweest die de cognitieve processen in problemgestuurd lleren heef bestudeerd. Zoals reeds eerder is vermeld, is het mocilijk te zeggen of bij grotere groepen de verhouding russen de caregorie scores in xle verbale interactie protocollen en de stimulated recall protocollen gelijk zal blijwen. Waarschijnlijk zijn er verschuivingen te verwachten omdat de groepsgroote wel bepertingen oplegr an het antal uitingen per student in de verbale interactic, maar geen invloed heeft op de uigebreidheid van de stimulared recall protoodlen.

De theoretische vragg hoe studenten omgaan met anomalieèn en of probleemgestuurd leren resulteert in conceptude verandering kan in positieve zin worden beantwoord. Er moet echter opgemerkt worden dat de classificarie van de protocolecnheden soms mocilijk was. Studenten geven informatic over her wel of niet aanvarden van informatie, maar wak geven ze geen verklaring voor de gegevens 
die zij accepteren. Daarmee wordt het moeilijk om de fijnere onderscheidingen, gesuggereerd door Chinn en Brewer, bijvoorbeeld tussen her uitshiren en verwerpen van tegenstrijdige gegevens, toe te passen. Onze analyse van het protocol van student $A$ suggereerde dat haar cognitieve representatie van de casus dramatisch veranderde tijdens de gezamenlijke analyse van die casus. Ze begon mer een stellige voorkeur voor de verklaring op basis van bloedvergiftiging (sepsis). Daana echrer werd zij regelmarig geconfronteend met verklaringen door anderen die hiermee tegenstrijdig waren. Haar eerste reactie hierop was om het voorlopig in beschouwing te nemen. Later werden deze gegevens geaccepteerd en leidden zij ror aanvaarding wan een nieuwe theorie, die op dat moment gezamenlijk werd geconstrueerd, hetgeen tenslotre leidde tot conceptuele verandering bij $\mathrm{A}$.

Her protocol van student A geefr ook inzichr in een antal factoren die beinvlocden hoe mensen omgaan met anomalieën. De factor voorkennis valt vooral op. Achtergrondkennis (kennis eerder geleerd) oetende een grote invloed wit op de construcrie van verklaringen. Onderdeel van thar achtergrondkennis was de combinatie van een rode streep op de arm en bloedvergifriging. Door de overecnkomst tussen deze achtergrondkennis en de casusbeschrijuing was het voor haar moeilijk om deze verklaring los te laten. Dit ging echter niet zover dat zij niet apen stond yoor andere verklaringen. Ook ontologische en kennistheoretische opvattingen speelden hierbij geen herkenbare rol. Deze combinatie wan kenmerken van de voorkennis kan verklaren waarom student $A$ haar ecrste verklating opgaf, een verklaring die zij in eerste instantie sterk aanhing.

Een andere factor die bepaalde hoe student $A$ reageerde op de tegenstrijdige informatie is de annwezigheid van een alternatiewe theorie. De excerpten laten zien dat de beschikbaarheid van een alcernatieve theorie, het mechanisme van de altermatieve theorie en de kwaliteit van de alternatieve theorie (vooral haar reikwijdte, cenvoud en vruchrbaarheid) een belangrijke rol speelden in het opgeven van oude idecën. Her is nier duidelijk of de accurarheid en consistentie van de alternatieve theorie een rol speelden.

De kenmerken van de tegenstrijdige informatie zelf vormilen ook een fictor alic van invloed was op hoe student A omging met deze informatic. Hoe studenten omgaan met anomaliceen hangt ook af van de bron wan deze informatic. In de srimulared reall protocollen waren soms opmerkingen te vinden over de gelwofwaardigheid van de bijdragen wan de andere groepsteden. Een ander kenmerk van tegenstrijdige informarie was de ambiguiteit ervan. In probleemanalyse is de informatie soms ambigue. Verder kan tegensorijdige informatie berekenen dat het meervoudige tegenstrijdige informatic is. Dit kenmerk is vooral belangrijk ondat in een groepsdiscussie de mogelijkheid van confrontatie met meerdere anomaliean groo is. Er is vak meer en verschillende kennis in cen groep, zodat een stuctent geconfronteerd kan worden met meerdere perspecrieven en dus meervoudige regen- 
strijdige informatie. In de getoonde excerpren stimuleren meerdere anomalieën student $A$ to acceptatic van bepaalde informatic.

Een latste factor die de reactie van een individu op tegenstrijdige informatie beinwoedt is de stratcgie die cen indiwidu heeft voor het verwerken van deze gegevens. Op een diepe manier verwerken van een anomalie bevordert conceptude verandering. In het excerpe van student $A$ is het eviden dat er een diepe manier van verwerken van tegenstrijdige informatie plaats vindt.

Deze studie onderzocht slechts de cognirieve veranderingsprocessen tijdens de problemanalyse fase van probleemgestuurd leren. Deze processen kunnen en zullen zich werder uitstrekken over de latere fasen wan zelfstudie en rapportage. Veranderingsprocessen die zijn begonnen in de analysefase, maar nog niet hebben geresulteerd in cen substantielle verandering, kunnen voortgang vinden in dexe fases. Onzekerheid over de theorieen of verklaringen die studenten hebben geconstrueerd, kumnen dat vereisen. Door deze onzekerheid worden afgewezen alternatieve theorieen nier volledig aan de kant geschoven, maar moeten door een ütgebreide fase van verificatie gaan tijdens de zelfstudie. Hetzelfde geldt voor die theorieën die zijn geconsmucerd en voorlopig geaccepteerd 
Hooldstuk 7

Probleemanalyse als methode om misconcepties te identificeren 


\section{Inleiding}

In Houfdstuk 6 is nader onderzoch wat de cognicieve en meracognitieve processen zijn tijdens probleemanalyse. Uit de analyse van de protocollen van de verbale interactic tijdens probleemanalyse bleek dat het geven vañ verklaringen central stond. Blijkbar stimuleert problemanalyse het zelf gencreren van verklaringen. In de experimenten uit Hoofdstuk 3, 4 en 5 is de nadruk komen te liggen op de faciliterende werking van het genereren van verklaringen in de groep voor het leren van nieuwe informatie. Zo is in de verschillende onderzoeken gebleken dat wanneer deze wookennis door middel van probleemanalyse in de kleine groep wordt geacriverd en wanneer daarop wordt geelaboreerd dit leidt tot het beter teren van de nieuwe informatic en ook toc een betere integratie van deze informaric in her kennisbestand. Voorkennis kin echrer ook belemmerend werken bij her leren en integreren van nieuwe informarie. Op verschillende terreinen is onderzoek gedaan naar de voorkennis van studenten die her leren van nieuwe informatie bemoeilijkt. Dit wordr wel aangeduid met het onderzoek naar misconcepties van lerenden (Smith, diSessa, \& Roschelle, 1994). Deze misconcepries zijn mer een grote varieteit aan onderzoeksmethoden onderzocht (Pfundt \& Duir, 1994). Veel van deze onderzoeksmethoden voor het identificeren van misconcepries zijn uitstekende onderwijsmethoden gebleken (Shuell, 1986; White \& Gunstone, 1992). In dit hoofdstuk wordt nagegaan of ook het omgekeerde her geval is, namelijk of een onderwijsmerhode zoals probleemanalyse in de kleine groep gebruikt kan worden on deze misconcepties van lerenden te identificeren. Probleemanalyse in de kleine groep vraagt van de studenten op basis van een probleembeschrijving verklaringen te genereren door middel van discussie. De veronderstelling is dat door het construcren van verklaringen de voorkennis geactiveerd wondt en hierop geëlaboreerd wordr en dat darmee de voorkennis en de kenmerken daarwan explicier gemaakt wordr.

\section{Het ontstaan van misconcepties}

Sudenten zijn geen onbeschreven blad wanneer zij nieuwe leerswof leren. Zij hebben reeds alleflei ervaringen on kennis opgedaan die wan invloed zijn op de nieuw te keren informatie. Deze kennis van beginners verschilt echter van die van gevorderden op her desberreffende kennisgebied. Daarom spreekt men bij een beginner ook wd van: preconcepties, altematieve concepties, naïeve opvatingen, of naïeve theorieen (zie voor een overzicht Smith, diSessa, \& Roschelle, 1994). Hier geven we echter de voorkeur aan de rerm misconceprie voor een conceptie wan een student, beginner of gevorderde, dic een systematisch patroon van fouten produceert. Her onderoek naar misconcepries heef een aantal zaken duidelijk gemakt (Gunstone, 1988: Smith, diSessa, \& Roschelle, 1994): 
- Misconcepries ontstaan door het voorafgaande leren varisudenten op school. of door interactie mer de natuurkundige of sociale wereld. Een bekend voorbeeld van een misconceprie die is onrstaan door alledaagse crvaringen in de ongang mer de wereld is die over kracht en beweging (Newtons mechanicil.

- Misconcepties kunnen stabiel en wijdverspreid zijn onder studenten. Misconcepries kunnen moeilijk te veranderen zijn en men kan er ook sterk an vathouden. Misconcepties kunnen optreden voor, maar ook nadat onderwijs op desbetreffend gebied heeft plaatsgeronden. Gunstone (1988) constateer bijvoorbeeld dat veel voorkomende misconcepties vaak opvallend weinig beinvloed worden door meer tradirionele vormen van onderwijs. Zo hobben sommige studenten tegelijkertijd schoolkennis en conflicterende opvatmgen die ze darvoor al hadden.

- Misconcepties interfereren met het leren van nieuwe informatie en met het verkrigen van expert-kennis op een bepaald kennisgebied.

Wat betreft verklaringen voor het ontstaan van misconcepties bij studenten constareren Fisher en Lipson (1986) dar er binnen de onderzoeksgemeenschap relaricf weinig consensus is over de oorzaken; evenmin is er een goede rheorie daarover beschilkbaar. In de literatuur vindr men hooguit inventarisaties van ooraken, met daarbij soms enige ordening (Felrovirch, Spiro, \& Coulson, 1989; Fischer \& Lipson, 1986; Hasweh, 1986, 1988; Linn, 1986). Daarbij worde verondersteld dat voor misconcepties over het algemeen niet éen duidelijke oorzak kan worden aangewezen. Fischer en Lipson noemen bijvoorbeeld de complexireit van de tc leren leerstof; het feit dat de leerstof conflicteert met de reeds bestaande eigen concepries; de neiging tot vereenvoudiging van de re leren informatie ("mental shortcuts"); het ex onvoldoende van bewust zijn of men iets begrepen theeft of niet (gebrekkige metacognitie); het feit dat er complexe relaties kunnen zijn tussen verschillende kennisgebieden, en tenslotte de manier warop men de leerstof leert, of dit op zo'n manier gebeurt dat er ook cen werkelijke integratic is tussen de voorkennis en de nieuwe informatie. Daamaast kan nog worden genoemd de verwarring tussen omgangstaal en wetenschappelijke taal (Hasweh, 1986). 1.unn (1986) voegr daar nog an toe het gebrek an vereiste voorkennis en het tekort schicten van leerboken. Feltovitch, Spiro en Coulson (1989) wijzen tenstore op nog een mogelijke ooraak wan misconcepties, namelijk de gebrekkige kennis over de leerstofbijde docent.

Naast de gesuggereerde oorzaken voor het ontstaan van misconcepties aijn er ideeen waarom dergelijke misconcepties, ondanks onderwijs op het desbetreffende gebied, blijven voorbestaan. Een belangrijke oorzak hiervoor kan zijn dat de student en/of de docent zich niet bewust zijn wan de misconceprie (Hasweh. 1988). Een andere reden die door zowel Hasweh (1986). Limn (1986) als Feltovitch. Spiro en Coulson (1989) wordr genocmd is her feit dat misconcepties een samenhangend geheel vormen: nicuwe misconcepties bouwen voort op reeds be- 
Tabel 7.1. Kennisopbouw van osmose.

1 De leerling zal een goed begrip dienen te hebben van de drie aggregatietoestanden gas. voestof en waste stof industel de specifieke wamtebewegingen van de deeltjes, van aller le variaties, waaronder die van oplossingen van gassen of vaste stofien in vloestof of van vloesstofmengsels, watbil de lering moet unzien wa concentratieverschll betekent De leerling moel zich woorstellen wat diffuste is, waarop hat berust en wartoe het leidi en datrbil diffusie weten te onderscheiden wan stroming.

3 Vervolgen dient de leenling de stap naar hel mathematische fick-model te maken. Dit is een vergande generalisatie en vadagt om allerle denkwardigheden $20 a$ is het op de goede wilze omgaam met allerle fysische grootheden en het dynamisch omgaan met de veriabelen in onderfinge samenhang, watrbilde complexteit van de diffusie coefficient genoend moet worden.

4 Vervolgens moet hij zeer snel overstappen naar het fenomeen semi-permeabel vies en zich dar een voorstelling van maken.

5 Hierop volgt de speciale vorm wan dffusie, die wij asmose noemen.

6 Het begrip osmose wordt al spoedig gekoppeld an drukverschinselen. waarvan de leerling het effect op diffusie moet begrijpen.

7 Dit resulteert in de definitie van osmotische warde.

staande misconcepties. Ook in het onderwijs kunnen oorzaken aanwezig zijn voor her voortduren van misconcepries. Zo kunnen evaluatiemethoden die in her onderwijs gehanteerd worden deze misconcepties onvoldoende signaleren. Tenslotte kunnen de strategieèn die een docent hanteert om de leerstof woor studenten eenvoudiger te maken (bijvoorbeeld gebruik van analogieen) de misconcepties van studenten bevestigen.

Korrom misconcepties zijn aanwezig bij beginners, maiar ook bij gevorderde leerlingen die reeds onderwijs hebben ervaren op desbetreffende gebied. Onderzoek maar misconcepries is op een aantal gebieden uitgevoerd (Pfundt \& Duit, 1994). lien belangrijk onderwerp binnen de biologic waar verschillende onderzocken nat nisconcepties zijn uigevoerd is osmose. Dit onderzoek naar misconcepries bij osmose wordt hicr samengevar en ook de onderzocksmethoden die daarbij gehantect zijn. De resultaten van dit onderzoek dienen als referentiekader om vast te stellen of probleemanalyse als onderzocksmcthode voor her identificeren wan misconceprics effectief is.

\section{Misconcepties over osmose}

Osmose is de diffusie van water door een semipermeabele membraan, zonder dat de in her water opgeloste stoften aan de diffusic kunnen deehemen. In het biologiconderwijs op het niveau van het voorgezer onderwijs is osmose cen belangrijk onderwerp. Kennis hiervan is noodzakelijk wil men biologische processen zoals wate ropname door planten en transport in levende organismen kunnen begrijpen. 
Osmose wordt door veel leerlingen echrer moeilijk gevonden. Johnstone cn Mahmoud (1980a) hebben onderzocht welke van een 15-tal biologie-onderwerpen door leerlingen en docenten uir het voorgezer onderwijs moeilijk werden gevonden. Uit dit onderzoek bleek dar zowel leerlingen als docenten osmose het moeilijkste biologieonderwerp vonden.

Osmose veronderstelt een bepaalde opbouw in kennis, die in Tabel 7.1 is weergegeven. (Dam-Eemnes, 1981, p. 50).

Daar komt nog bij dat bij de roepassing van osmose bij dierlijke en plantaardige cellen kennis van deze cellen verondersteld wordt.

Een belangrijk en omvatrend onderzoek naar misconcepties over osmose is het onderzoek dat is uitgevoerd door Johnsione en Mahmoud (1980a). Zij probeerden de misconcepties op te sporen met behulp van een tweetal methoden, namelijk her groepsinterview en vier toetsen van het type juist-onjuist irems. Her grocpsinterview werd roegepast bij 8 groepen wan ieder 6 leerlingen variërend in leefrijd wan 15 tot 17 jaar. Twee van de vier toetsen werden gebruikt bij leerlingen van 15 tor 16 jaar, de andere twee werden gebruik bij leerlingen wan 16 ror 17 jar. De toetsen waren gebaseerd op de resultaten verkregen uit her groepsinterwiew.

In hun onderzoek idenrificeerden zij een zestal gebieden mer misconcepries bij leerlingen. De eerste misconceptie betreft de onjuiste ideeën van lecrlingen over "oplossen". Leerlingen hadden namelijk geen duidelijk idee over de relatic tussen de op te lossen stof en het oplosmiddel. De oorzak van deze misconceptie was een simplificatie van de leerstof in een eerdere fase van de opleiding, die nu echrer een belemmering werd voor werkelijk begrip. De tweede misconceptie werd veroorzaakt door het onjuist gebruik wan de termen "sterk" en "zwak" bij oplossingen. Dit leidde tot her onjuiste idee dat geconcentreerde oplossingen "sterk" genoeg zijn om water weg te zuigen bij de zwalkkere oplossing. Een derde misconceptie heef eveneens te maken met terminologie. Dir is namclijk de verwaring bij beginners wat betreft de stroming die van laag potential naar hoog porential verloopt. Dit gaat in tegen het onderwijs in natuurkunde en scheikunde. Een vierde misconceptie berreft het idee van equilibrium. Zelden was er enig begrip wan dynamisch equilibrium bij studenten te winden. Verder was er verwarning bij leerlingen ower de gebruikte tekens voor osmotische druk, cel-wanddruk en waterpotentiaal. Tenslotte slaagden leerlingen er waak niet in osmose bij planten re begrijpen. ondanks dat ze her laboratoriummodel van osmose wel begrepen. Oortalk hicrvan was de misconceptie bij leerlingen dar wanneer een plant gevoed word door de aarde er meer "voedsel" in de arde moet zitten dan in de plant, d.w. . de atrde-oplossing zou meer geconcentreerd mer opgeloste voedingsstoffen moeten riju dan de oplossing in de plancencellen.

De werklaringen die Johnson en Mahmoud (1980a; 1980h) geven voor her ontstaan van deze misconcepries zijn kort samengevat: 1. gebrek aan de noodzakelijke 
kennis van de natutikunder 2 onjuist gebruik van teminologie. 3. het niet kunnen tocpassen van cerder geleede kennis; 4 . gebruik van verwarrende tekens; 5 . oversimplifikatie van leerstof. 6 . her feit dat osmose een complex begrip is en abstract redeneren vereist. Een gevolg van deze zaken is volgens Johnsrone en Mahmoud (1980a; 1980b) dat leerlingen (op her macroniveau) enige vuistregels leren zonder enig begrip van de verschijnselen. Men komt niet toe aan verklaringen op her microniveau, oftewel moleculair niveau.

In een onderzoek bii studenten heeft Murray (1983) misconcepties geidentificeed war berrefe de centrale begrippen voor osmose, namelijk concentrarie, semipermeabiliteit, en druk. Murray onderzocht hoe stabiel deze misconcepries zijn ondanks onderwijs op desbetreffende gebieden. Vir de onderzoeksresultaten bleek dar her begrip concentratie anvankelijk nogal wat misconcepties opleverde, maar dat onderwijs erin tor gevolg had dat veel van deze misconcepties verdwenten. Her begrip semi-permeabiliteit, het onderscheid daarvan met urij permeabel en impermeabel en de roepassing van het begrip semü-permeabel waren voor de studenten aanzienlijk mocilijker, ondanks onderwijs daarin. Volgens Murray wordt dic enerzijds veroorzaakt door her feit dat het verschijnsel semi-permeabel niet direct warnembar is. Een andere reden is dat er in her onderwijs onvoldoende onderscheid word gemaakr tussen experimenten welke semi-permeabele en impermeabele membranen gebruiken. Tenslotte is er het begrip "druk" in osmotische verschijnselen. Uit het onderzoek bleek dat bijzonder weinig studenten, ook na onderwijs, hier iets van begrepen. Volgens Murray word dit veroorzaalet doordar misconcepries over dir begrip ontstaan door het verwarren van de betekenis van het begrip druk in de omgangstaal met dar van de wetenschappelijke taal. Een andere oorzaak voor misconcepties over her begrip druk is dat in de biologie zelf er ook onduidelijkheid is over dir begrip.

Friedler, Amir en Tamir (1987) hebben onderzock gedaan naar misconcepries over osmose bij leerlingen in her voortgezer onderwijs. Een wijfat verschillende onderzoeksmethoden werden hicroor gebruikr, namelijk: 1. een vagenlijst waarin ecn viffriental begrippen opgenomen was (osmose en andere gerelateerde begrippen) an waathij an de leerlingen werd gevragd on an te geven of ze deze begrippen hatden bestudeed; 2. dezelfde vagenlijst werd ook zo gebruikt dat leerlingen konden angeven of en in welke mate ze deze begrippen begrepen hadden: 3 . een roets met items van ther type juist/onjuist; 4. de opdrach definities te formuleren over asmose en diffusic; 5 . een individueel interview. Uit de onderzockscesultaten bleek ten eerste dar de meest frequente verklaring die door leerlingen werd gegeven voor het osmotisch proces een teleologische verklaring is: cen wens of monief van de betrokken stoffen om te komen tor her gelijkmaken van concentratics. Studenten schijnen volgens Friedler. Amir cn Tamir te geloven in het bestan van een morief, net als menselijke morieven, die de kracht levert welke de watermoleculen beweegt. Een rweede onderzoeksresulaat was dat hoewel ved 
studenten her begrip waterconcentratie kumnen herkennen slechrs weinigen her kunnen toepassen on osmose te verklaren. Een ander resultaat van her onderzock was dat de meeste leerlingen misconcepties hebben over de aard van een equilibrium. Verder hebben de leerlingen speciaal moeite met het begrijpen wan osmotische relaties in planten door de introducrie van exrra begrippen zoals celvacuole en celwand, welke het systeem complexer maken. Daardoor worden verschijnselen als plasmolyse vaak niet goed begrepen. Ook hebben veel leerlingen mocite mer het begrijpen van de relatie tussen de op te lossen stof en het oplosmiddel en concentratie-kwanticeit relaties. Tenslotte bleek uit de onderzoeksresultaren dat leerlingen laboratorium-experimenten kunnen uitvoeren, zonder werkelijk begrip van de onderliggende principes. Friedler, Amir en Tamir (1987) staan vooral stil bij de inventarisatie van misconcepties. Factoren van belang woor her ontstaan en voortduren van misconcepties worden bij hen slechts in beperkte mate gekoppeld aan de door hun gevonden misconcepties.

Amir, Frankl en Tamir (1987) onderzochten bij her onderwerp osmose hoe effectief de onderzoeksmethode multiple choice vragen (met daaraan gekoppeld de instructie tot het geven van rechrvaardiging van her gekozen alternatief) is voor het identificeren van misconcepties. Dic onderzoek werd uitgevoerd bij leerlingen uir het woortgezet onderwijs. Uit dit onderzoek bleek dat weel leetlingen her begrip waterconcentratie niet begrepen en dat veel rechtvaardigingen wan het proces van osmose de kenmerken hadden van teleologische verklaringen.

Odom (1995) tenslotte onderzocht of misconcepties over osmose niet alleen voorkomen is het woortgezet onderwijs, maar of ze ook woorkomen bij biologiestudenten die reeds uitgebreid onderwijs op dit gebied hebben gehad. Uit dit onderzoek bleek dat zelfs bij gevorderde biologiesrudenten misconcepties aanwezig waren op het gebied van osmose.

De in bovenstaande vermelde onderzoeken zijn expliciet gericht op her verschijnsel osmose, daamaast kunnen echter nog de resultaren wan onderzocken wemeld worden die gericht zijn op her opsporen van misconcepties op declaspekten van her proces osmose. Zo zijn er bijwoorbeeld misconcepries geidentificeerd war becreft diffusie (Marek, 1986) en her begrip cel (Dreyfus \& Jungwirth, 1988; Dreyfus, Jungwirth, \& Eliovitch, 1990).

Uit de resultaten van in bovenstande beschreven onderzocken naar misconcepries bij osmose blijkt dat er nogal wat misconcepties over dit onderwerp bij leerlingen a anwezig zijn. Zowel bij beginners als bij meer gevorderde lecrlingen. Dus ondanks onderwijs op her gebied van osmose bliff er bij lerenden een gebrekkig begrip van het biologische proces war eraan ten grondslag ligt.

Tevens blijkt uir de onderzoeken dat er cen variatie aan onderzocksmethoden zijn gebruikt voor het idencificeren van misconcepties, zoals onder andere grocpsinterview, juist-onjuist toetsen met rechtyaardigingen, multiple choice vragen, vragenlijsten en individuele interviews. In de literatuur vind men cen grote vartatic van 
deze onderzoksmethoden (Pfundt 8 Duir, 1994) waarbij overigens opvalr dat individuek incervews overheesen. De nadruk die door Johnstone en Mahmoud $(1980$; 10806$)$ werd gelegd op her groepsinuerview in plaars van het individuele inceview is woor deze studie van belang. Zij constateerden namelijk dat de discussic en interactic in het groepsinterview vale het meest watedevolle is wat betreft het leveren yan aanwijingen voor misconcepties. In misconceprie onderzok word in toenemende mate de nadruk gelegd op onderzoeksmethoden die gebasect zin op inceractic voor het vastsellen van de concepties van studenten (Pfundt \& Duit, 1994). Van belang voor her onderzoek waarover in dit Hoofdstuk word gerapportect is een suggestie van Shuell (1986). Shuell meent namelijk dat onderzocksmethoden voor her identificeren van misconcepties gebruikt zouden kunnen worden als onderwijsmethoden. Gunstone (1988) wijst erop dat sommige merhoden die zijn gebruikr voor her onderzoeken van de cognitieve strucuur van studenten uirstekcnde onderwijs/leerstrategieèn zijn. Voorbeelden hiervan zijn 1 . de predict/observelexplain methode en concept-mapping. Deze latate methode word ook in probleemgestuurd leren gebruike (De Grave \& Frijns, 1993).

Probleemanalyse is cen onderwijsmethode, die potentieel ook geschikt lijkt te zijn als onderzoeksmethode om misconcepries re identificeren. De veronderstelling is namelijk dat door het genereren wan verklaringen in een kleine groep elaboratie sterk gestimuleerd wordt, wardoor in de geconstrueerde verthlaringen de aard wan de voorkennis zichtbaar wordt en daarmee ook de misconcepries bij lerenden die van invloed kunnen zijn op her verdere lecrproces.

In her in dit hoofdstuk beschreven onderzoek werd de methode problemanalyse in kleine grocpen gebruikt om de misconcepries die leerlingen en srudenten hebben onurenc osmose te identificeren en om ma te gaan of probleemanalyse in de kleine groep en geschikte merhode is om misconcepties te identificeren. In een experiment werd aan groppics middellare scholieren zonder en met specifeke workennis (hegimers en gevordenden) en aan ecrstejaurs hbo studenten (gevorderdenj cen problem vourgelegd met als opdracht via discussic roved mogelijk verklavingen re bedenken voor de verschijnselen in de problecmbeschrijving. Deze discussics werden op geluidstand opgenomen. Via analyse van de protocollen werden conceptien die de lechingen en studenten hebben van onderliggende proacsen of mechanismen voor de verschijnselen, opgespoord. Voor dit experiment werd en biologisch onderwerp genomen dat onderded uimaakr wan her VWO curriculum.

\section{Methode}

Profpersenen waren 22 derdeklassers en 21 vierdeklassers wan een atheneum. Gemiddelde lectijil van de derdeklasse scholieren was 14,9 jaar, die van de vierde- 
klassers 16,1 jaar. Her betrof dezelfde proefpersonen als die deelnamen an her in Hoofdstuk 3 beschreven onderzoek. De proefpersonen uit de derde klas hadden geen specifieke kennis van osmose en diffusie, alhoewel ze de beschikking hadden over algemene biologische kennis, waronder globale kennis van de structuur van cellen. Ze worden hier verder beginners genoemd. De vierdeklassers hadden her onderwerp enige weken daarvoor gehad, zij waren de gevorderden in dir onderzoek.

Een derde groep proefpersonen waren 22 studenten aan twee instellingen voor hoger beroepsonderwijs die bezig waren aan hum eerste jaar. Her berrof dezelfde proefpersonen als die deelnamen aan her in Hoofdscuk 4 beschreven onderzoek. In dit onderzoek worden zij evenals de vierdeklassers WWO gevorderden genoemd. De gemiddelde leefuij van deze studenten was 18,7 jaar. Allen waren in het bezit van een HAVO-diploma en waren geéxamineerd in het wak biologie. De proefpersonen ontwingen een vergoeding voor hun medewerking.

\section{Materiaal}

Het materiaal bestond uit een beschrijving wan het rode bloedcelprobleem, dat ook in het onderzoek waarover in Hoofdstuk 3 en 4 is gerapporteerd werd gebruikt.

\section{Procedure}

Beginners, gevorderden en hbo-studenten werden binnen hun eigen conditic aselect in kleine groepen van ongeveer gelijke grootre ( 5 a 6 studenten) ingedeeld. Aan elk van deze groepen werd een proefleider toegewezen. Deze legde kor uit wat er van de proefpersonen verlangd werd, aan de hand van een geschreven voorbeeld. Het voorbeeld voor beginners en gevorderden bestond uit het onweer probleem. In dit probleem werden verschijnselen van onweer beschreven dic verklaard dienden re worden. Voor de HBO srudenten bestond dit voorbeeld uit cen beschrijwing van het gedrag van een plan dic zuurstof afgeef bij daglicht, mat nier in het donker. Deze problemen werden geanalyseerd vanuir verschillende perspectieven en er werden een aantal mogelijke verklaringen besprokon. De prodfeider betrok de procfpersonen actief bij zijn uirleg om er zeker van te zijn dar zij begrepen wat er straks van hen verlangd zou worden bij de analyse van het blocdcelprobleem. Hij benadrukte dat wan hen verwacht werd verklaringen te bedenken woor her probleem en die verkjaringen kritisch te bediscussieren. Ze werden angemoedigd alles wat er bij hen opkwam nat voren te brengen. Daze introductio nam 5 tot 10 minuten in beslag. Vervolgens kregen de prodpersonen 15 minuten om verklaringen te bedenken woor het bloedcelprobleem. De proefleider fungeerde daabij als gesprekleider, die de produktie van ideeen stimulectde en deze van rijd tot tijd samenvatte. De discussie werd op band opgenomen om nate gaan of de proefleider geen informatie over her probleem verschafe. Geen van de 
groepen had meer dan 10 minuren nodig voor de analyse wan het probleem. De geluidsbanden werden na alloop uitgetypt en $\mathrm{de}$ resulterende protocollen vormden de basis voor meer gederailleerde analyses.

\section{Resultaten}

\section{Concepties van begirners}

De beginners moesten cen verklaring construeren voor her bloedcelprobleem. Zij hadden gecn onderwijs gehad in diffusie en osmose, maar zij beschikren wel over basale kennis van de cel. Op basis van deze onvolledige kemnis werd door redeneren, door op clkaar voort te bouwen of door elkaar te krinseren verklaringen geconstruect. In de protocollen van de verbale interactie vinden we de verschillende verklaringen terug, thamen met andere verbale uitingen van studenten (zie de categoriecun verbale uitingen genoend in Hoofdstuk 6 ). In de analyse van de protocollen zijn wij meer geinteresseerd in de verklaringen dan in deze aanvullende informatic. Om een indruls te geven op welke wijze door beginners verklaringen werden gegeven voor her bloedcelprobleem, volgt nu een fragment wit het protocol van een discussie bij een groep mer beginners (N).

Procfleider (P): "Tja, wil iemand dar wat over zeggen?" (stilte gedurende enige seconden) "IIs moeilijk, hè".

Proefpersoon 1 ( $P$ Pl): "Ja, het enige wat ik weet is dat er twee bloedlichaampjes zijn, een rode en een wirte, hè,"

P. "Ja..."

Ppl: "Dat was het enige."

P. "En hier gat het blijkbaar over een rood bloedlichampje; een van die twee.

Kan iemand uidleggen war ermee gebeurt?"

Pp2: "In zout, datir droogt hij misschien uute."

P: "Ja..."

Pp2: "Dat her datrom krimpt."

P. "Ja, je zegt..."

Pp2: "Zout ontrekt... eh... onttrekt vocht, want dat is ook als je bijvoorbeeld cen wijnwlek in een tafellkleed hebt, dan gooi je er gellijk zout op, en dat neemt dat dan op, dan gaat het uit her rafellaken. Dus ik denk dar dan (..) bij het blocdlichampje, als het in het zout is dat het zour ook het bloed ontrekt aan de bloedcel, en dar die datom krimpt".

(Gedecle uit protocol beginners (N3, pag. 1)

Het blocdeelproblecm is blijkbat complex woor de studenten, want zij delen het problem op in deelproblemen. Zo genereren zij afzonderlijk werklaringen voor 
het zwellen (en barsten) en woor het verschrompelen van de rode bloedcel. On cen indruk re krijgen wat voor verklaringen er worden gegeven woor de rwec verschillende condities waarin de bloedcel zich bewind zijn deze gedestilleerd uit de verschillende protocollen van de begimners.

In de Tabellen 7.2 en 7.3 zijn deze verklaringen voor het bloedcelprobleem weergegeven. Daar deze verklaringen telkens deelverklaringen zijn voor de wwee afzonderlijke situaties zwellen en ineenkrimpen wan de bloedcel, zijn de verklaringen op deze wijze geordend.

Tevens is er een conceptie die gaat over zwellen en inkrimpen van de rode bloedcel. Op basis van de opvatring dat de rode bloedcel poreus is werd geconstateerd: "Ja her water kan erin en eruit, of zuurstof en daarom kan her ook opzwellen en inkrimpen." (N1, pag. 4).

Kenmerkend voor deze door leerlingen gegenerecrde idecën is dat het allemat partielle verklaringen zijn, in de zin dar of her zwellen of her inkrimpen van de bloedcel word verkJard. De relatie tussen verklaringen voor beide verschijnselen komt slechts nu en dan aan de orde. Een gevolg hiervan is dat zuurscof als verklaring voor her zwellen rustig naast zout voor het inkrimpen word gesreld, zonder de relatie errussen te problematiseren. Blijkbaar is het probleem voor de beginners zo complex dat hun niets anders overbliff dan het problem in subproblenten op te delen.

De verklaringen die voor de deelproblemen worden gegeven zijn onjuist of onwolledig. De meeste onjuiste ideeën worden slechrs een enkele keer genoemd. Eén conceptie die vaker terugkomt is her idee dat zout water aantrekt hergeen verwijst naar de hygroscopische eigenschappen van zout (zie concepties: zwellen: 2 en 26; krimpen: $3,5,7,8)$. Deze verklaring heeft een sterke basis in ervaringskennis en af cen toe een verwijzing naar schoolkenmis.

Zout ontrekt, want dat is ook als je bijvoorbeeld een wijnwlek in her tafelkleed of zoiets hebt, dan gooi je er gelijk zout op en dar trekt dar zout en neeme dat dan op. dus dan gaat het uir het afellaken, dus ik denk dat wannecr het blodlichampje in het zout is, dat her zout ook het bloed ontrekt aan de bloeded on dat hij darom inkrimpt. (N3, pag. 1)

Gezien het veel woorkomen van deze conceptie en doordan deze gewortcld is in observaries lijkt dic een moeilijk te veranderen conceptic van de beginners. Een ander soort verklaring die meerdere keren in de protocollen voorkome, gaat over de onmogelijkheid van het barsten van de rode bloedecl. Het barsten van de bloedcel is blijkbaar strijdig mee de intuitic van de studenten (zwellen concepties: 6. 14, 16, 24). "Als je er meer cellen in zou doen, dan zou hij nict zo kapot gaan, bij ved cellen neemt ieder war en als er mateen is nemt hij teveel (zuurstof) op". (N1, pag.2). Daarom geeft men verklaringen in de zin van: "de bloedcel is mat alleen, bij meerdere bloedcellen of in het licham barse hii nict." (N3, pag.2) Bij deze verklaringen gebruike men intuiries en algemene kennis over her lichaam. 
Tabel 7. 2. Conceptes woo het zweltentbarsten wan de bloedcel.

1 "Hil neent hel water op, en omdat het zoweel water is, ja dan springthij kapot". (N), pag. I)

2 "lk derk dat het zout er tets mee te maken heeft". (HN1, pagl.1)

3 "En ja hoe het precies komt weet ik ook niet Ik denk dat het iets anders is. Dat het riet het vocht is, mal dat hel met het water, wat in het water zit, iess te maken heeft. (N1. pag. 1)

4 "Mischien zitten in hat water bepalde voedhgstoffen of 20 , dat de bloedce teveel opneemt en dat die den kapot springt". (N1, pag. 1 )

5 "lk derk dat hif door de zuurstof kapot gaat". (N1, pag Z)

6 "Als je er meer cellen in zou doen, dan zou hi net zo kapot gaan, bij veel cellen neemt ieder wat en als er maar ean is neemt hil tevel(zusustof) op". (N1, pag. 2)

7 "Ja dat bioedichampje zal wel poreus zijn, dat water erin en eruit kan, of zubstof en daarom kan het bloedichaampje opzwellen en inkrimpern". (N1, pag. 4)

8 "Misschien heeft dat bloedlicheampje een soont ventiel", (N1, pag. 5)

9 "Nanneer nou iets allen maar een bepaalde tijd heeft, net zoals een vis die kuit schiet en dan gatat hij dood, misschien is dat hetzelfde". (N1, pag. 5)

10 "Die wand zäl wel elastisch zijn en als ze zover is uitgerekt dat ze dan niet meer verder kan untrekken, als een ballon". (N., pag. 5)

1. "ik derk dat er megr water in kom als er ut kan. En dat hij dan groter wordt "(N), pag.5.

12 "Ik dent eender dat er niet water in dat bloedlichaampje gaat, maar dat er zuurstof in komt. Omdat dat lichaam, dat heeft zusurstof nodig. Waa lad je die zuurstof dan. Want ik denk in het licham heeft de bloedcel ook de takk om zuarstof op te nemen en te ververen en ciat die bloedcel dat in water ook wil doen en dat hij dan kapot gaat. "(N1. pag.6.)

13 "k denk dat die rode bloedcel dat water dam opneemt en als hij dan zo wall zit dat hij kapot springt", (N2, pag. 1)

"4.4 "Vandat water, dat kan wolgens mij helemal niet want in dat bloed, dat kan toch niet dan spring je toch niet kapot". (N2. pag 11

15 "As je een ballon opbladit dan springt hij ook". (N2, pag. 2)

16 "In de bloedwaten daar zit geen zuiver water in daar drijuen allemaal rode bloedcellen in want anders zouden ze allemaal kapotspringen". (N2. pag. 2)

17 "I $k$ denk dat hij van alle kanten tegelijk water oppaki, en dan komt het bij ekaar in het midden of $z 0$ en dan steeds meer, en dan ploft hil uit elkad, kan hii het niet meer houderi". (N2, pag. 3)

18 "klk denk dat het gewoon een aantrekkingskracht heeft dat het bij zich blift zitten". (N2, pag. A)

19 "Ja er zal wel een of andere chemische of scheikundige verklaring voor zijn. la ik denk dat het ge. woon ligi aan het soort stof waar hif uit bestat". (N2, pag. 4)

20 "Mischien bestaat die rode bloedcel uit allerlei kleine deeltjes die dat water allemaal opzuigen en dan hebben ze geen plats meer, dus ze zwellen allemaal een beetje op en dan zwellen ze zoveel op dat zo mekaar weg duwen en dat gaat dan zover dat ze op het laatst unt mekaar sprngen". (N2, pag. 4)

21 "Misschien dat er ook lets van kleppen inzitten, dat het wel erin kan maar miet eruit kan. (W2, pag. 4)

22 "Als een biloedcel in water komt dat het dan just opneemt. Dat het daardoor teveel opneemt en dat de wand van de cel het niet kan houden, en spat en det het daardoor springt". (N3, pag. 1 )

23 "In de biologie, die rode bioedlichampjes die ja wewoer en toch vain alles en denken ze ook dat ze water moeten vervoeren en proberen ze dat allemaal op te nemen. " $(N 3$, pag. 1$)$

24 "Want anders zijn ze met meer bloedlichampjes in een ruimte of zo als ze het vervoeren, dus dan neemut iedereen wat op maar als je dan mal een bloedlichaampje in water dar... ja dan blyfit hij volgens mij opnemen en dat hil daardoor springt. (N3, pag. 2).

25 "Het bloedithampje is poreus", (daandoor kan er water inkomen) (w3, pag. 2).

26 "lk denk dat er zout in dat celletje zelf zh, omdat die dat opnemen of 20 " (N3, pag. 4). 
Tabel 7.3. Concepties ower het inkrmpen van de bloedce

1 "Ja ik denk dat in die zoutoplosing, dat de bloedcel zout opoeamt en dan inkrimpt" (N), pag. 1)

2 "Dat dan een andere reactie geef dan zout met water omdat no zout zt geloof ik NACl of zo en chloor zit geloo ik ook in water en als het dan samen tevel word of 20 dat die bloedcel er niet meer tegen kan en dat hij dan ineenschrompelt

3 "Misschien is het zo dat zout het wodit erut haal, dat het water ankekt"

4 "Dat hil dat zout, dat hij daar gewoon door wordt aangetast". (N2. pag. 1)

5 "Doordat zout wordt er water aan onttrokken" (N2, pag. II)

6 "Het water, waarn dat zout is opgelost is nog aitujd zouter dan dat water in die rode bloedcel, dus ik denk toch dat dat word onttroken an die bloedcel $1 \mathrm{~N} 2, \mathrm{pag} .3)$

7 Ik denk zout neemt zelf ook water op en dat trekt ook water aan, dus deardoor zal het ook water onttrekken aain die rocie bloedcel" (N2, pag. 4)

8 "Zout onttrekt, want dat is ook als je bijwoorbeed een winviek in het tafelkleed of zoiets hebt, dan goo je er gelijk zout op en dat trekt dat zout en neent dat dan op, dus dan gat het wit het tafellaken, dus ik denk dat wanneer het blodichampie in het zout is, dat het zout ook het bloed onttrekt aan de bloedcel en dat hij daarom inkrimpt. (N3, pag. 1)

9 "Zout water geeft een grotere druk dan gewoon water" (N3, pag. 3)

10 "Ja maar toch moet die druk van buten groter zinn dan in de cel anders kan hil niet inkrimpen." (N3. pag. 4)

Voor verschillende andere concepries grijpt men terug op metaforen en analogieèn. Zo vindt men herhaaldelijk de metafoor van de ballon woor het awellen van de bloedcel (zie zwellen: concepries ar.: 10, 15) en her elastische karakter van de membraan van de bloedcel. Verder wordt het zwellen van de od geassociecred met een spons (zwellen conceptie nr.: 20). Een zelfde conceptie werd ook door Johnstone en Mahmoud (1980a; 1980b) gevonden. Over het membran van de bloedcel zijn ook rerugkerende voorsteflingen, zoals poreus (awellen: conceptic n. 7, 25) en verder ventiel (zwellen concepries nr.8) an kleppen (zwellen conoeptic nr. 21). "Misschien dat er ook iets van kleppen inzitten, dat het wel erin kan matr nict ctwir kan". (N2, pag. 4)

Voor her verklaren van het zwellen wan de bloedeel worde verder gehruile gemaalat van meer specificke kennis uit de biologie zoals ze deze op school gelect habben. Zoals kennis over de funcrie wan rode bloedlichampjes; namelijk wervore win zuurstof. Deze kennis wordt gebruikt in de zin wan analoog redencren, bijwormbeeld de conceprie die stelt dat rode bloetcellen tot rak hebben om suurswol op te nemen en dat ze dan ook wel tor taak hebben om water op te nemen. (rwellen concepties nr. 12, 23). Tevens worde deze kennis gebruikr voor her vinden van corzaken (zie concepries 3, 4, 5). 
Ik denk eerder dat er niet water in dar bloedlichaampje gaat, maar dat er zuurstof in kont. Omdat dat lichaam, dat heeft zuturstof nodig. Waar laat je die zuurstof dan? Wane ik denk in het lichaam heeft de bloedcel ook de taak om zuurstof op re nemen en te vervoeren en dat die bloedcel dat in water ook wil doen en dar hij dan kapor gaat. (N1, pag. 6)

Verder kenmerken verschillende concepties zich door de vorm warin ze gesteld zijn. Allereerst betreft dit de vorm van teleologische en antropomorfe verklaringen. Een curieus voorbeld vat een releologische verklaring is: (krimpen conceptie n.9) "Wanneer nou iets alleen maar een bepaalde tijd leeft,... ner zoals een vis, die schier kuit en dan gaat hij dood. Misschien is dit herzelfde" (N1, pag.5) Teleologische en antropomorfe verklaringen werden ook frequent door Friedler, Amir en Tamir (1987) gevonden.

Het is voor de beginners moeilijker een wat complexer verklaringsmodel te construeren. Een conceptie waarin een zo'n verklaringsmodel wel enigszins aan bod komr, is de conceptie waarin gesproken wordt van druk. "Ja maar toch moet die druk van buiten groter zijn dan in de cel anders kan hij niet inkrimpen." (N3, pag. 4)

Natast deze overeenkomsten tussen de protocollen is er een variatie aan opwattingen over de oorzaken van het gedrag wan de bloedcel in de twee verschillende condiries.

Wanneer deze concepties wergeleken worden met de beschreven kennisopbouw van osmose, dan vallen de volgende zaken op:

1. Kennis over de materie en over oplossingen worde niet of nauwelijks teruggevonden. Uitzondering is de nadruk op de hygroscopische eigenschappen van zour als verklaring voor de verschijnselen, waarbij men echter voorbij gat aan her feit dat er sprake is van een zoutoplossing. Fén keer vindt men in een protocol een opmerking over de aard van oplossingen: "Ja maar hier staar dat het zout, dat is al in de oplossing, dus er zit al water eigenlijk in het zout, dus her zout lost op in warer, dus her neemt al water op van die oplossing zelf. "(N2, pag. 3). Het begrip concentratie komt men in de protocollen niet tegen.

2. Verwijzingen naar diffusice en welke facroren daabij een rol spelen ontbreken in de protocollen.

3. Concepties over de celmembraan (functies en kenmerken) zijn in de prorocollen uirsuitend te vinden in de zin van analogieën on metaforen.

4. In de concepties voor de verklaringen van het bloedcelprobleem is al geconstateerd dat men onjuiste of onvolledige idecën heeft over de oorzak van osmose.

5. Wat betreft de rehatie van osmose met drukverschijnselen: in slechts één prorocol is er sprake van de introducric van het begrip druk woor de verklaring van de verschijnselen.

Her problecmoplossingsgedrag wan de beginners bij her bloedcelprobleem komt op een aantal punten overeen met wat we weten uit onderzoek naar her leren van 
beginners. Allereerst is er de complexiteir van her probleem. In de protocollen hebben we gezien tot wat voor soort problemoplossingsgedrag dit heeft geleid. Dit rype probleemoplossingsgedrag kan een fixarie op deelaspekten van het probleem tor gevolg hebben, waardoor men de onderliggende mechanismen niet kan herkennen. Een dergelijk problemoplossingsgedrag is kenmerkend voor beginners in vergelijking ror expercs. Her kom overeen met resultaten van onderzoek naar het oplossen wan medisch diagnostische problemen, waarin bleek dat middel marig ervaren medische studenten een beschrijwing van klachren en symptomen van een parièn opdeelden in afzonderlijke klachten en voor elk van de klachten "minitheorierjes" ontwierpen, terwijl experts zochten naar concepten die de klachten in hun onderlinge samenhang konden verktaren (Boshuizen, Schmidr, Coughlin, 1987).

Een ander kenmerk van beginners is dat ze zich vooral op de perceptuele kenmerken van een probleem richten, terwijl experts een probleem representeren op een meer diepgaand en abstract niveau (Chi, Glaser, \& Farr, 1989). Dir gegeven wordt ook weer teruggevonden in de verschillende protocollen. Beginners zijn sterk gericht op de waancembare aspecten aan het rode bloedcelprobleem. Zij zijn sterk gericht op verklaringen voor het zwellen, barsten en krimpen.

De verklaringen die de beginners geven zijn onjuist of onvolledig, met andere woorden we hebben hier te maken met misconcepries. Deze misconcepties zijn echter geconstrueerde misconcepties. Deze misconcepries maken geen deel uit van het kennisbestand van de leerlingen, maar zijn het resultaat van elaboraties. In dit onderzoek bij beginners hebben we te maken met geconstrueerde misconcepties op basis van het aan de leerlingen gepresenteerde bloedcelprobleem.

\section{Concepties van gevorderden}

De gevorderden (oudere vwo leerlingen en hbo studenten) hadden het onderwerp osmose reeds in hun studic gehad. Voor de kwo leerlingen was dat wat korter geleden, voor de hbo studenten was dar beduidend langer geleden. Zij hadden dus systemarische kennis verkregen op her gebied van osmose. Zij moesten nu op basis van het bloedcelprobleem hun kennis omtrent de onderliggencle processen en mechanismen van osmose roepassen.

De verklaringen van de gevorderden zijn anders van karakier dan die van de beginners.

Het volgende gedeelte is afkomstig van een groep gevorderden. 
Proefleder Zou ienand dic kunnen samenvarten?

Proefpersoon: Je hebr te maken met twee tegenover elkar gestelde problemen, her knappen van de bloedcel of het inkrimpen. Dar knappen en inkrimpen van een bloedcel dat gebeurt naar aanleiding van bepalde concentratieverschillen binnen en butiten de cel. Als een bloedeel knapt dan komt dat omdat er binnen de cel een hogere concentratie heerst dan buiten de cel, waardoor door middd van osmose water naar de cel wordt getransporteerd. Bij het andere geval is er sprake van dat er buiten de cel en hogere concentratie is waardoor vanuit de cel warer naar buiten gaat en dan krimpt hij weer ineen"

(G2. pag. 3)

De geworderden passen een oplossingsstrategie toe die eruit bestaat een theorie te construeren die de verschillende fenomenen met behulp van een of twee principes verklaar, zoals in het hierbowen weergegeven fragment.

De verklaringen echer die voor het bloedcelprobleem gegeven worden, zijn hoofdzakelijk op het macroscopisch niveau, terwijl een begrip van de relatie tussen macroscopisch en microscopisch niveau essentieel is voor een goed begrip van osmose (Berkheimer, Anderson, \& Spees, 1988; Kapteyn, 1990; Lijnse, et al., 1990). Typen verklaringen op macroscopisch niveau zijn bijwoorbeeld de verklaring van osmose in termen van concentratiegradiënt (Johnson \& Mahmoud 1980a: 1980b). In bovenstaand fragment vinden we een dergelijke macroscopische verklaring. De protocollen van de groepen met studenten vertonen op veel punten gelijkenis mer de protocollen van de gevorderde vwo-ers. Ze komen sterk overeen mer wat bij de discussies in de groepen met gevorderden te vinden is wat betreft aard en niveau wan verklaringen (nadruk op macroscopisch niveau). Dar de nadruk lige op de macroscopische verklaring blijkt uit verschillende fragmenten van de protocollen van gevorderden. Vooral worde dit duidelijk wanneer er gesproken wordt over diffusie. Dit begrip wordt verduidelijkr door terug te gaan nar een experinent, beschreven in de biologieboeken, waarin een bak met water is en een schor ertussen. "Een grote bak met een schor ertussen en twee verschillende stoffen. Je haalt het schor er weg zodar die stoffen in elkaar kumnen vlocien. "Het volgende fragment illustreert de sterke nadruk op het macroscopische (waarnecmbarc) niveau van verklaring van diffusic.

Maar hoe vindt die diffusie plats?

Dat kan je gemakkelijk zien als je bijwoorbeeld een glas neemt en je giet er hee vomrzichrig wat ranja in en als je dat even laat staan dan zal dar hele glas precies dezelfde kleur kriigen. (G2, pag. 2) 
In de protocollen van de gevorderden zijn verschillende misconcepties vast te stellen. Zo zien we ook bij gevorderden concepties in de vorm van teleologische verklaringen. "Maar hei streven on al die cellen in leven te houden is natuurlijk wel dat die concentraties gelijk zijn en daarom trekr dat naar elkaar toe". Vaak vindr men in de protocollen de verklaring dat het concencratieverschil de oorzaak van osmose is, met daaraan toegevoegd: "en er is een streven om de concentraties gelijk te maken" (Friedler, Amir, \& Tamir, 1987; Amir, Frankl, \& Tamir, 1987).

Perkins en Simons (1988) noemen een drieral zaken waar studenten, die net kennis op een bepaald gebied hebben verworven, problemen mee kunnen hebben. 1 . ongedifferentieerde begrippen en begrippen waarvan het belang onjuist wordt ingeschar; 2. problemen mer vermenging van de net verkregen kennis, en 3. moeilijkheden in de toegankelijkheid van de verkregen kennis. Deze zaken kunnen we in de protocollen van de groepen gevorderden constateren: zo wordt er bijvoorbeeld nier altijd en goed onderscheidr gemakt van begrippen zoals osmose en diffusie (zie ook Friedler, Amir \& Tamir, 1987; Marek, 1986).

In onderstaand fragment uit een protocol van gevorderden staat her onderscheid tussen diffusie en osmose centraal:

$\mathbb{P L}$ Dus er gat alleen maar warer doorheen door dat membraan.

Pp1: Ja, dus is het diffusie

Pp2: Nee, osmose

$\mathrm{Ppl}$ : Bij diffusie is er sprake van een wand

$\mathrm{Pp} 2$ : Nee dat is uitwisseling van stoffen

Pp3: Ja, maar niet door een semi permeabele wand

Osmose is met behulp van een semi permeabele wand.

Pp4: Bij diffusie worden twee stoffen bij elkaar gevoegd

Pp2: Osmose gaat alleen met water dacht ilk.

(Fragment uit G1, pag, 2/3)

Fen begrip waarover in de protocollen ook veel verwarring is te vinden is het begrip concentratic, waarbij de termen zoutconcentratie en waterconcentratie door studenten gebruikt worden (zie ook Amir, Frankl, \& Tamir, 1987; Friedler, Amir, \& Tamir, 1987; Johnsson \& Mahmoud 1980a; 1980b). Her volgende fragment illustreer deze verwarring. 
Ppl. Dan is er juist her tegenovergestelde aan de hand. Dan gaat al het water uir de bloedcel en schrompelt hif ineen.

Pp2. Dus dat berckent dar dic bepalde concentratie van her water veel groter moerzijn.

Pp3. Nee, de concentratie buiren de bloeded is groter dan de concentracie van zour in de rode bloedcel.

PP2. De concentratie van het water ja. De oplossing van zout in het water.

Pp3. De concentratic van het zout dus gewoon.

P2. Nee zout heeft geen concentratie. De concentratie zit in het water.

Pp4. Omdat er zout in zit

Pp3. Het begrip concentratie is ons ook zomaar bijgebrachr. Als ik er goed over nadenk weet ik ook niet zo precies wat concentratie is. Ik zou niet kunnen uitleggen wat concentratie is.

(Fragmenc uit G5, pag.3)

Wa betreft de toegankelijkheid van kennis, deze blijkr onder andere uir de afwewigheid van bepaalde begrippen bij her verklaren van osmose en door het geen relaric kuninen leggen tussen verklaringen op het macro- en microniveau.

ben onjuiste verklaring van het blocedclprobleem, die bij de beginners sterk aanwezig was vinden we ook weer rwec keer terug bij de gevorderden. Dir is de misconceptie die stelt dar de hygroscopische eigenschappen van zour de verklaring zijn woor de verschijnselen van het bloedcelprobleem:

Proefleider: Nou kan jij er wat van zeggen, of Carien of zo?

Pp2: " Ja, ik denk, die rode bloedcel ja, of ja, hier bij dat zout ja, zour heefr gewoon een sterkere osmose of zo, en zout trekt water aan, dus dan gaat dat water wit die cel en dan schrompelt die ineen". (ragment uit protocol G3)

Uit de koppeling van de kennisopbonw van osmose met de informatie uit de protocollen van de gevorderden blijkt onder andere: 1. Kennis van materie (gassen, vlocistuftion en vaste ston), warmebewegingen van deelyes, valn oplossingen en van concentratic word weing of net gebruiki bij de verklaring van osmose. Wanneer her wel gebruikr wordt is her een bron van misconcepres (bijw. hygroscopische eigenschap van zout als verklaring voor het bloedelprobleem); 2. De kennis over dithic bij de studenten is beperkt; valk that men een voorbeeld wit her biologiebock ian. dat men dan nog ecn keer beschrifft. Het blift oppervlakkige kennis, men geboruike wel woorden als diffundeert, maar kan dar nier verder uitleggen. 
Ook zijn er geen verwijzingen naar facroren van invloed op diffusie; 3. De kennis van semipermeabel whies is gedifferentieender. Hier wordt meer het onderscheid gemaakt russen celwand en celmembraan. 4. De kennis van osmose betreft vooral verklaringen in rermen van concentratieverschil, waarbij begrippen als hyper-, hypo, en isotonische oplossingen aan bod komen. 5. Er is meer kennis van drukverschijnselen bij osmose. In de protocollen zijn verwijzingen naar begrippen als turgor, maximale druk en osmorische waarde te winden. In het kader van plantencellen worden deze drukverschijnselen uirgelegd.

Uir de aard van de verklaringen die gevorderden produceren blijkr dar deze, ner als experts meer abstracte principes hanteren om de verschijnselen re verklaren (Chi. Glaser, \& Farr, 1988). Daarbij is het echer de vraag of er een voldoende integratie van kennis heeft platsgevonden tussen de verschillende niveaus van verklaring (macroscopisch versus microscopisch). Doordat men nier direct deze relatie legt. ook niet dan nadat daarop doorgevraagd wordt, is deze kennis blijkbaar nict erg. roegankelijk.

\section{Conclusies}

Doel van dit onderzoek was na te gaan of onderwijsmethode problecmanalyse ook een goede onderzoeksmethode is voor het meer zicht krijgen op de voorkennis en onjuistheden hierin van lerenden. Hierroe werden de verbale protocollen van probleemanalyse bij beginners en gevorderden geanalyseerd op de aanwezige verklaringen. Deze verklaringen als produkten van cognitieve en metacognitieve processen zouden inzicht moeten bieden in de voorkennis. Uit de resultaten van dit onderzoek blijkr dat probleemanalyse stimuleert tot een sterke acrivatic van de voorkennis. Dit blijkt uit het aantal en de grote variatie aan verklaringen dic (vooral bij beginners) worden gegenereerd. Deze verklaringen laten zicn dat heel verschillende kennisgebieden door probleemanalyse worden geacriveerd, variërend van ervaringskennis tor schoolkemis. Naast deze variatie an verklaringen zijn of ook cen aantal overeenkomsten geconstarcerd. Zo blijkr dar ar accurate, matr ook inaccurate verklaringen zijn voor her proces van osmose. Tevens zijn cr overecnkomsten an te geven wat betreft vorm en inhoud van de verklaringen. De inaccurate verklaringen (misconcepties) zijn begrijpelijk bij de beginners angezicn her hier geconstruecrde misconcepties zijn, matar ze komen ook woor bij gevorderde sudenten. Uir de onderzoeksresultaten blijke dat problecmanalyse in ieder geval die misconcepries blootlegt die door andere onderzokers mer verschillende andere onderzoeksmethoden ook worden gesignaleerd (Johnson \& Mahmoud, 1980a; 1980b; Fiedler. Amir, \& Tamir, 1987; Zuckeman, 1994a; 1994b; 1995). Daarnaast echter levert deze onderzoeksmethode zelfsen nicuwe misconceptic op. Het feir dar misconcepties voortduren ondanks onderwijs op dat gebied blijkr ubt de gevonden concepries bij gevorderden. Deze onderzoeksresultaten komen overeen 
mer meer longitudinal georiënteend onderzock door Odom (1995). Samenvattend kan gesteld worden dar uir cleze onderzoeksresultaten blijkt dat probleemanalyse, zelfs bij niet getrainde proefpersonen, als onderzoeksmethode voor her identificeren van (mis) concepties bij lerenden succesvol is. Men mag verwachten dat bij getrainde proefpersonen en docenten die het proces van elaboratie in de groep nog verder kunnen stimuleren deze concepties nog beter te identificeren ziju.

De reden waarom probleemanalyse in de kleine groep succesvol is heef watschijnlijk te maken met her gegeven dar studenten gevraagd wordt in groepswerband te elaboreren. Hef geven van verklaringen in interactie met andere leden wan de groep heeft een aantal cognirieve en metacognirieve processen tor gevolg zoals die in vorig hoofdstuk zijn beschreven. Door interactie in de groep worden niet alleen de misconcepries meer zichtbaar, maar ook meer bewust voor studenten en docent. Interactie russen groepsleden en de kwaliteir daarvan is dus essenticel voor het feir of de methode probleemanalyse in de kleine groep bruikbaar is en meer biedr dan andere methoden wat berreft de identificatie van misconcepties bij lerenden. De methode lijkt vooral vruchtbaar daar waar her probleem zo'n niweau van complexiteit heeft en nieuw is voor lerenden dat er op basis van onvolledige kennis verklaringen geconstrueerd worden en elaboraties tot stand komen. In de prorocollen xiet men bijvoorbeeld bij beginners de misconcepties als her ware "ontstan". 
Hoofdstuk 8

Algemene discussie 


\section{Inleiding}

De studies in dit profschrift hebben als centrale vragstellingen "Wat zin de effecten van probleemanalyse in de kleine groep op het leren wan nicuwe informatic?" en "Welke cognitieve processen vinden er plaats tijdens probleenanalyse?". Probleemanalyse in de keine groep (als onderded van probleemgestuurd leren) heefr als functic her genereren van verklaringen voor bepaalde verschijnselen. Her zelf genereren van verklaringen en dan vooral met behulp wan inceractie in de groep is een belangrijke strategie voor het werkelijk integreren van de nieuwe informarie mer de voorkennis van de lerende (Chi, Bassok, Lewis, Reimann, \& Glaser, 1989; Mayer, 1996; Pressley, Wood, Woloshyn, Martin, King, \& Menke, 1992; Webb \& Sulivan-Palincsar, 1996). De belangrijkste cognitieve verklaring voor de effecten van problemanalyse worde gevonden in de elaboratie theorie (Norman \& Schmide, 1992; Schmidr, 1993). Her leggen van relaties tussen wat men al weer en het nicuwe word elaboreren genoemd.

In dit hoofdstuk worden allereerst de resultaten van deze studies besproken in het licht van de elaboratie theorie. Onderzocht wordt wat deze studies bijdragen aan een empirische ondersteuning van deze theorie en wat de generaliseerbaarheid is van de onderzoksresultaten. Op basis van deze analyse wordt vervolgens aangegeven welk vervolgonderzoek nodig is. "Tenslotte worden de consequenties van deze studies voor de onderwijspraktijlk besproken.

Onderzoek naar effecten van probleemanalyse op het leren van nieuwe intormatie

Het experimenteel onderzoek dat in dit proefschrift is gepresenteerd, veronderstelt cen annall theoretische aanmamen die aan probleemgestuturd leren ten grondslag liggen. Door middel van problemanalyse in de kleine groep elaboreren lerenden op hun voorkennis hetgeen verondersteld words re leiden tor en betere organisatic en bewustwording van die kennis en daardoor to een betere toegankelijklacid en bruikbarheid ervan. Dat zou op zijn beurt een betere verwerking van nicuwe informatie bevorderen, resulterend in een betere geheugenprestarie. Ook het patroon in de reall zou door elaboratic veranderingen vertonen, namelijk een tocname in verklarende proposiries en minder in beschrijvende proposities en een tocname in het aanal inferenties in de recall. In Hoofdscuk 3 is een experiment bescheven, watrin onderzocht werd wat her differentiele effect was van probleenanalyse bij beginners en gevorderden. Uit de resulaten van dir ondernok blijke inderdaad dat problecmanalyse leidt tot het zich beter herinneren van de stadietekst. Ook de recall patroon van de onderzockstesultaren ondersreunt de elaboratierheoric. Over het algemeen genomen is in dit onderzock de claboratie theoric het meest consistent met de gevonden onderzocksresultaten. In het experiment dat beschreven is in Hoofdstuk 4 werd verondersteld dat in de drie groepen van het onderzoek 
(acrivatietaak, individuele probleenanalyse, probleemanalyse in de groep) een toenemende mate van elaboratic aanwexig zou zijn, met als effect een toename in het leren en onthouden van informatie uit de studietekst. De onderzoeksresultaten ondersteunen deze veronderstelling, gezien het lineaire verband wan het effect. Ook het patroon van de recall is consistent met de elaboratie theorie hoewel de verschillen klein en niet significant zijn. Dit onderzoek laat zien dat interactic eenn srimulans kan zijn voor elaboratie, maar wijst tevens op de mogelijk negarieve offecren van interacrie Het onderzoek dat in hoofdstuk 5 beschreven is roonde aan dat probleemanalyse bij een meer ecologisch valide leeromgeving leidde tot een betere geheugenprestarie wat betreft de nieuw geleerde informatie. Her patroon van de recall (onderscheid beschrijwende/verklarende proposities) was echter anders dan verwacht. Ook het aantal inferenties was nier significanr verschillend tussen de condities. Kortom de onderzoeken ondersteunen over het algemeen de elaboratie theorie, maar laten tevens op enkele punten tegenstrijdige onderzoeksresultaten zien vooral. wat betreft het patroon van de recall.

Er is nog weinig onderzoek gedaan naar de wijze waarop probleemgestuurd leren in de kleine groep deze posirieve effecten produceert. Her onderzoek dar in Hoofdstuk $6 \mathrm{en} 7$ is gepresenteerd, geeft meer inzicht in de cognirieve en metacognirieve processen die tijdens probleemanalyse platsvinden. In Hoofdstuk 6 blijkt uir de analyses van de protocollen dar probleemanalyse werkelijk leidt rot het construeren van gëlaboreerde verklaringen. Ook de rol en her belang van interactie in de groep voor zelfgegenereerde elaboraties wordt in dit onderzock verduidelijkt. Zo blijkt in de protocollen van de stimulated recall dat door interactie in de groep tegenstrijdige informatie gegenereerd wordt voor de verschillende verklaringem woor het problem. Deze tegenstrijdige informatie stimuleert tot een sterkere elaboratie. Tevens ontstaat door interactie in de groep een soort gemeenschappelijke verklaring voor het probleem. De protocollen van de stimulated recall illustreren dis verschijnsel mooi, doordat proefpersonen in de stimulated recall verwijzen nat een groepstheorie voor de gegeven verschijnselen. Uit her onderzoek naar do cognitieve processen tijdens probleemanalyse in de groep blijkt verder dar her proces wan conceptuele verandering goed interpreteerbaar is vanut de theorie over conceptuele verandering (Chinn \& Brewer, 1989).

In Hoofdstuk 7 staat het probleem van de accuraatheid van de elaboratic central. Door de verbale interactie te analyseren op de kenmerken van de geproduccerde verklaringen, blek dat zowel bij beginners als bij gevorderde leerlingen tijdens problecmanalyse misconcepties zichobaar worden. Het onderzock naar de misconcepries bij beginners en gevorderde leerlingen rijdens probleemanalyse in de kleine groep slaagde erin misconcepries te signaleren dic ook uit ander onderzoek, warin andere onderzoeksmethoden werd gehanteerd, naar voren kwamen. Ook werd mer behulp van probleemanalyse een nieuwe misconceptie geidentificeerd. 
Het experimentele en het meer kwaliatief gerichte onderzock in dit proefschrift laar echter ook nog vragen open. Een belangrijke vraag is die naar de exreme validireit van dit onderzoek. Het experimenteel onderzoek heef zich bijwoorbeeld beperkt tor een bepuald leerstofgebied en de complexiteir van de leerstof, kenmerken van de proefpersonen/groep en andere ecologisch belangrijke variabelen voor onderzok natar de effectiviteit van deze worm van cooperaniefleren. In hen molgende gedeelte wordt het in dir proefschrift gerapporteerde onderzock geanalyseerd mer betrekking ror de generaliseerbaarheid van de onderzoeksresultaten.

In her onderroek dat in Hoofdsuk 3 is beschreven werd gevonden dar probleemanalyse en groter effect had op het leren van nieuwe informarie bij beginners dan bij gevorderden. Encrzijds worde dit ondersteund in de onderzoeksliteratuur anderzijds is dit strijdig met overzichuen van ander onderzoek naar de effecten van claboraties op het leren van teksten. Sahari (1997) in een metanalyse van onderzoek naar de effecten van elaborarie op her leren van teksten, concludeert bijvoorbeeld dar het hebben van meer voorkennis op een posinicve wijze de elaboratie kan beinvloeden. Dit effect word volgens hem bij toename van voorkennis sterker. Ook Pressley. Wood, Woloshyn, Martin, King en Menke (1992) constateren dax de grootste effecten van elaboratie-activiteiten zich voordoen bij volwassenen, die over meer kennis beschikken. Hoewel de type claboratie-activiteiten in deze onderzoeksoverzichten sterk verschillen van probleemanalyse lijkr nacer onderzoek op dit gebied vereist.

Wat bereft de leerstof en de complexireit daarwan, hier is bijwoorbeeld niet duidelijk of de effecten van elaboratie door middel van problecmanalyse van toepassing zijn op leerstof wan verschillende moeilijkheidsguad. In de eerste rwee experimenten berrof de leerstof osmose. Dit is het moeilijkste onderwerp in het biologieonderwijs op het woortgezer onderwijs. De vraag is of vergelijkbare effecten gevonden zullen worden bij leerstof die door scudenten niet zo moeilijk wordt gevonden. In onderock watrover verslag is gedaan in hoofdstuk 5 , is gebruik gemaakt van een kerstofdomcin (blocddrukregularic) dat complexer is mar op het gebied van de medische kennis niet tor de top behoort van mocilijke basisleerstof (DawsonSitunders, Feltovitch, Coulson, \& Sroward, 1987; De Grave, Boshuizen, \& Snellen-Balchdong. 1994). Het zou kumen xijn dat probleemanalyse geen roegevoegde warde heeft bij de verwerking van meer cenvoudige leerstof, en dus een omslachrige weg is on doelen to bereiken die ook op eenvoudiger wripe bereik kunnen worden. Meer onderzok naar de effecten van probleemanalyse bij verschillende mare wan complexiteit van leerstof is daarom nodig.

Een andere beperking van het onderzoek is dat, om de gekozen onderzoeksvragen en hyporhesen te kunnen beantwoorden, een reducrie heeft platsgevonden van hoe problecmgestuud leren in de prakrijk van her onderwijs ferellijk verioopt. Her onderzock beperkte zich tot de fase van het analyseren van een probleem. In de prakrijk besteden studenten ook veel aandacht aan het formuleren van leerdoe- 
len; vragen die men door zelfstudie wenst te beanrwoorden. Probleemgestuurd leren in de onderwijsgroep voorafgaande an het bestuderen van cen srudierekst is dus een combinatie van verklaringen en vragen genereren. In onderzoek is gebleken dat het genereren van verklaringen cen positief effect heeft op her leerproces (Pressley et al., 1992). Eveneens is in onderzoek gebleken dar zelf geformuleerde wagen voorafgaande aan her leren van reksten het leren hiervan bevorderen 10 sman \& Hannafin, 1994). Pressley er al. (1992) constareren dar onderzoek naar de gecombineerde effecten wan verklaringen genereren en vragen genereren op het lcren van studieteksten een interessant onderzoeksgebied vormt. De vraag is dan naruurlijk of de effecten die geproduceerd worden door het genereren van vragen opgeteld kunnen worden bij de effecten die ontstaan doordat men verklaringen genereert.

De opzer van de verschillende experimenten in dit proefschrift week verder af van de feitelijke wijze waarop probleemgestuurd leren in de prakrijk verloopt, in deze zin dat studenten niet gevraagd werd de geleerde tekst na afloop te verbaliseren. De taakscructuur van probleengestuurd leren is namelijk dar studenren na cen periode van zelfstudie worden geache hun opgedane kennis in de groep onder woorden te brengen. Hoewel verondersteld kan worden dat in het onderzoek, dat beschreven is in Hoofdstuk 5, de geneeskunde studenten van deze verwachting uitgingen is deze instructie niet expliciet vermeld. Uit een overzich van onderzoek nata her leren van teksten concludeerden Pressley en Aflerbach (1995), dat relatief weinig aandacht besteed wordt aan de sociaal-contexuele wariabelen. Zo kan een lerende rijdens het bestuderen wan een tekst gericht zijn op een sociaal criterium, zoals of genoeg geleerd is om deze kennis in een daropwolgende discussie te kunnen gebruiken. Machiels-Bongaerts (1993), zich baserend op de cognitieve setpoint theorie van Schmidt, suggerecrt dat, wanneer een lerende weet dat hij zijn kennis moet presenteren aan anderen dit het set-point niveau doet verhogen als gevolg van sociale druk. Zo bleek bijvoorbeeld in een onderzock van Kingen (1983) warin proefpersonen die een tekst moesten bestuderen, gevangd werden zich voor te bereiden op een groepsdiscussie, op cen mecr diepgaande manier deze tekst bestudeerden. Een dergelijke instructic zou dus cen duidclijker makstructum voor de proefpersonen op kunnen leveren, die nauwer ansluit bij het proces van probleemgestuurd leren in de onderwijsgroep. De veronderstelling is dar met deze instructie erbij claboratie op de nieuwe informatie in sterkere mate zal platsvinden en daamee zal leiden tor cen sterkere integratie van de nicuwe informatic in de reeds a anwezige kennis. Dit zou tot gevolg hebben dat er meer geleerd wordt. Een derde afwijking van de wijze watop probleemgestuurd onderwijs is ingericht berreft het feit dat de free recall toets in de experimenten direcr na de bestudering van de studietekst is afgenomen. In probleemgestuurd leren starten studenten pas na een rijdsinterval met de studie naar aanleiding van de leerdoelen in de onderwijsgroep. Free recall is vooral gevoelig woor het vaststellen van inferenties in de re- 
call (als efect van claborates) na een anzienlijke rijdsinterval. Dit lijkt erop re wijen dat integrate wan kennis een kwestie van wijd is. Norman en Schmidt (1992) vermelden bijvoobed onderzoken mat de offecten wan cursussen die op problecrugerwunde wijze werden gegeven, vergeken mer conventionele cursussen, warin gerapporterd word dat efecren van problemgestuurd leren pas na verloop van tid opreden. Meer ond raok is dus nodig waarbij op meerdere nomenten effectmengen uingevoerd moeten worden. In de sudies is werder gebrukt genalk van free recall, de vaag is echer of de effecten ook te vinden zijn bij andere vomen van toetsing van kemnis, zoals bijwoorbeeld toenen dic vragen om roepassing van de verkregen kenuis.

Tenslotce wijkt de experimente opzet van de ecrte dric onderzoeken af van de reale situatie in de onderwijsgroep wat betreft het feit dat de proefleider als gesprekleider optrad. Deze gesprekleider had specifie instructies hoe te handelen. In probleemgesturd onderwijs is er echter sprake van ean additionele functie, namelijk dic van rutor. De curor (de docent) heef als tak het leerproces te oprimaliseren en darmee ook de elaborate te optimaliseren (Schmidt, 1994 , Schmidr 8 Moust, 1995). Onderzock naar problecmgesuurd leren of andere vormen van cooperatief leren warbij deze variabele berokken wordr is nodig (zie ook Ros, 1992) Verondersted mag worden dat de tutor in het bijzonder bif de verwerking wan moeilijke leerstof en positieve inwloed kan hebben (Schmide 8 Moust, $1905)$

In deze studies nar de effecten van probleemanalyse op hed leren van niewwe informatie moeten meer specificke eisen gesteld worden aan het onderzoeksdesign, om te kunnen onderscheiden ussen de verschillende verklaringen. Bijvoorbeeld on te kunen onderscheiden russen de elaborate en motivatie verklaring (A Jexander, Kulikowich, \& Schulze, 1994; Schraw, Bruning \& Svoboda, 1995). Praktsche overwegingen leggen echter beperkingen op aan dergelike experimenten in meer realistische situaties.

De resultaten van het onderzock natr de cognitieve en metacognitieve processen (Hoofdstuk 6) xijn ook terug te winden in ander onderzok In onderzoek nar de not van interactic voor de leeprocesen wan lerenden wond Roschelle (1992) bijvoorbeld dat de kem van samenwe then her probleem wan convergente is, dat wil zeggen dar cen groep kom tot gedecle kenin is en een convergentie wan betekenis dic an begrippon, ervaringen of verkaringen worden gehecht. Erkens (1997) conchulecr wit analyses van de takuinowng en dialoogvoering van samenwerkende weetallen dat de coördinacie van het proces van informatie-uitwisseling en sannenwerken vooral onderseund wordt door focussing, checken en argumentatic. Bij checken an argumentatie spelen bijvootbeeld regenstrijdige informatie, plausibilicair wande informarie en onderhandekn van betekenis een rol. Her proces van convergantio van berekenis con onderhandeling van betekenis is echter nog onvoldoende duidelike en zal werder onderzocht moeten worden. 
Het onderzoek naar de identificatie van misconcepties met behulp van de methom de probleemanalyse (Hoofdstuk 7) doet de vrang rijzen of xelfgegenereerde elaboraties (ongeacht of deze accuraat of niet zin) een positief effect hebben op het leren van nieuwe informatie of dat zelfgegenereerde elaboraties in de groep zo accurat mogelijk moeten zijn om posirieve effecren re hebben (Schmidr. De Volder. De Grave, Moust, \& Parel, 1989; Pressley, McDaniel, Turnure, Wood \& Ahmad, 1987). Deze vraag is bijvoorbeeld van belang voor de rol van de tutor (begeleider van her probleemgestuurde leerproces). Moet de tutor foutieve denkwikzen tijdens de probleemanalyse laten gaan (zodat ze rijdens zelfsudic kunnen leren wan fouten) of moet hij/zij stimuleren dar studenten bewust worden varn de misconcepties en deze bijstellen, zodat meer accurate elaboraries plaatsvinden voorafgande aan de studie.

\section{Suggesties voor verder onderzoek}

In de analyse van de generaliseerbarheid van de studies zijn reeds cnkele gebieden aangegeven waar mogelijk verwolgonderzoek zou kunnen gebeuren. Samengewar betreffen deze: de kenmerken van het leerstofdomein; de kenmerken van de taakstructuur van probleemgestuurd leren; kenmerken van de roersing van kennis en kenmerken van de facilitatie van problecmanalyse door de docent. Daarnaast zijn een aantal factoren aan re geven die mogelijk de effecriviteir van elaboratie door middel van probleemanalyse in de kleine groep kunnen beinvloeden. Dir zijn bijvoorbeeld de kenmerken van her probleem, als startpunt voor het probleengestuurde leerproces. Her belang van een goed geconstrueerd probleem voor het probleemgestuurd leerproces wordt angegeven in modellen voor probleemgestuud leren (Schmidt \& Moust, 1995). Andere factoren die mogelijk de elaboratie in de groep en daarmee de effectiviteit van probleemanalyse voor het leerproces kunnen beinvloeden zijn kenmerken van de groep. Hierbij kan bijvoorbeeld gedacht worden aan de samenstelling van de groep (bijv. heterogeen/homogeen), de groepsgrootre en kenmerken wan de groepsleden (bijwoorbeeld lecrsiji). Tenslorre lijk raining en oefening, zowel van studenten als docenten, een belangrijke facror te zijn voor het oprimaal laten verlopen van elaboratie rijdens probleemanalyse (Webb \& Sullivan Palinesar, 1996). In theorievorming over coöperatief leren (Slavin, 1991; Webb \& Sullivan Palincsar, 1996) en in theoricvorming over probleemgestuurd leren (Schmidr, 1993; Schmidr \& Moust, 1995) worden deze factoren meer in samenhang weergegeven. Onderzoek naar de effecten van dext faccoren kan en bijdrage leveren aan een verderc empirische onderbouwing van de elaboratietheorie

In de theoric over probleemgestuurd leren wordt er van uitgegaan dat problecmanalyse ook werkelijk leidr ror elaboratie. Kennis over welke denkprocessen feirelijk plaatsvinden tijdens probleemanalyse in de groep is echter beperkt. Dit is een belangrijk hiaat in de theorievorming. Her onderzock waarover in Hoofdstuk 6 is 
gerapporteend, hecf meer kennis opgeleverd over dexe cognitieve processen. Onderzock op dit gebied is noodzakelijk om meer zicht te kriggen op wat effectieve inreractic is vanuir her perspectief van het leerproces van de lerende. Onderzoek naar de cognitieve processen tijdens probleemanalyse is echter niet voldoende. Wat verder ontbreckr is on-line onderzoek naar de cognitieve processen tijdens de zelfstudiefase, zodau kan worden nagegaan wat de invloed van probleemanalyse in de groep is op de cognirieve verwerking van nieuwe informatie. Hierbij kan gedacht worden aan de aard wan de inferenties die worden gegenereerd tijdens de studie en aan de verdeling van aandachtover de verschillende onderdelen van de studierekst. Meer specifieke kennis van dergelijke cognitiewe processen biedt een bredere verklaringsbasis voor de effecten van probleemgestuurd leren zoals die in dir proefschrifr beschreven zijn. Het proces en de voorwaarden van conceptuele verandering kunnen op deze wijze beter in kaart worden gebracht.

In hoofdstuk. 7 is onderzocht hoe effectief probleemanalyse misconcepties van lerenden over de leerstof kan identificeren. Kennis omtrent misconcepties, de oorzaken erwan, en de oorzaken waarom ze ondanks onderwijs op dir gebied voortduren is essentieel in de context van probleemgestuurd leren. Onderzoek naar de rol wan inaccurate elaboraries (misconcepties) tijdens her proces van probleemgestuurd leren zowel tijdens probleemanalyse als tijdens de fase waarin studenten rapporteren over de zelfstudie kan cen bijdrage leveren aan een optimalisering van het proces van probleemgestuurd leren. In dergelijk onderzoek dient ook de rol van de begeleider wan her probleemgestuurde lecrproces (de tutor) voor het veranderen van misconcepties nagegaan te worden.

Implicaties voor het onderwijs

De ervaring met probleemgestuurd leren leert dat de wijze warop probleemanalyse word uitgevocrd niet altijd optimaal is. Srudenten thebben nogal eens de neiging dezx fase op een oppervlakkige en weinig diepgaande manier te behandelen. Dir komt clan onder andere tor uiring in het feir dat srudenten soms slechrs korte tijd besteden aan de discussie en dan snel overgaan naar de fase van leerdoel formulkeren. Op deze wijze zal er minder geëlaboreerd worden. Daardoor worden de beoogde effecten van problexmgestuurd leren (Noman \& Schmidt, 1992) in mindere mate gerealiseerd dan mogelijk is. Het onderzoek dat in dic proefselvrift beschrewen is late zien hoe belangrijk probleemanalyse is voor het leerproces van studenen. Zowel studenten als docenten zal duidelijk moeten worden gemaakt watr dexe fase concreer inhoudt, op welke wijze deze fase optimaal verloopt, en tot welke leereffecten dit leidt. Kennis van proces en funcrie van deze fase is noodzakelijk on de kwaliteir ervan te bewaken. Dit geldo zowel voor studenten als docenten. Concreet betekent dit dat studenten wanneer zij aan her begin van hun studie geinntroduceerd worden in probleemgestuurd leren kennis moeten krijgen van kenmerken en funcrie van deze probleemanalyse. Ook bij de training van docen- 
ren voor de rol wan turor, zal andacht bested moeten worden an kenmerken en functie van deze fase en wat te doen wanneer deze fase nict opeimal werloppr. Een belangrijke reden waarom deze fase in de praktik van probleemgesunted leren in da onderwijsgroep niet alrij optimal verloopt zijn onjuste opvarungen bij studenten en docenten over aard en functie van deze fase. Zo denken studenton vakd dat het er in deze fase alleen om gat alles op te hoesten wat ze weten. Darbij werwarlozen zij het constructieve katakrer wan deze fase. Pas doou het construeren wan verklaringen on redeneringen en het constan bijstellen en veranderen wan deze ontstat werkelijke clabonatie. Daabij kunnen ook verklaringen of denkexperimenten die verder gaan dan wat men "wee" belangripk zin. In zekere zin moet men creatief zijn. In het onderzoek nat het proces van probleenanalyse dac beschrewen is in Hoofdsuk 5 en 6 wordt dit construcrieve karakter wan problemanalyse duidelijk. Ook voor docenten is het van belang om een juiste opwating te hebben wan de constructieve ard van deze Fase. Wanneer studenten bijwoorbeeld slechts wat ideeen ophoesten zal hij of zij hen moeren stimulenen tor het construeren van verkiangen en tot het opbouwen van tedeneringen. Tevens zall dic proces gestimuleed worden wanneer de tutor anomalieen introduceert en andacht besteed aan de voorwarden voor conceptuele verandering. Slechts wanner cr werkelijk elaboratie optreed kan dit van invloed zijn op her verwerken en onthouden van de nieuwe informatie.

Tenslotte is een belangrigke voorwatde voor het op gang komen van claboratie rijdens probleemanalyse her hebben van een goed probleen. In de prakrijk van probleemgestuurd leren echter zijn er soms problemen gemaakt dic helcmal niet raadselachtig of problematiserend zijn en dexe vormen dan ook geen uirdaging om een constructieve denkacriviteit te ontplooien. In het formuleren van goede problemen gatareel denkwerk zituen en dan nog bliff het moeilik om acn probleem goed af re stemmen op de doelgroep. Wanneer en probleem duidelijk ninder stimuleert tot discussie hangt het sterk af van de interventies van de cutor of en constructicf denkproces op gang gebrache worde. Bij hee onrwerpen van con problecm. voor problemgestuurd leren zullen de constructeurs van het problem zich con becld moeten vormen van welke constructieve denkactiviteich zullen ontstan op basis van her probleem. Wanneer de feicelijke denkprocesson te sterk afwijken van wat men verwach, dan zal men rerug moeten gann nar her probiech om dic bij te stellen. 


\section{Samenvatting}

\section{Inleiding}

Probleemgestuurd leren in de kleine groep is een wijze van leren waarin wordt uitgegaan van een constructiviscische benadering van het leerproces en van het belang van interactie voor het leren. In dit proefschrift staat de eerste fase van het proces van probleemgestuurd leren centraal, namelijk de probleemanalyse dic voorafgat aan de feitelijke studie. Probleemanalyse is de fase warin studenten gezamenlijk verklaringen genereren voor een voorgelegd probleem. Her is cen methode om de lerenden te stimuleren nieuw te leren informatie actief te relateren aan wat men reeds weet. Dit wordt ook wel elaboreren genoend. Doel van de studies die in dit proefschrift gepresenteerd worden is een verdere empirische onderbouwing te bieden voor één van de claims van probleemgestuurd leren, namelijk dat probleemgestuurd leren leidt tot het beter leren en onthouden van de nieuwe informatie (Barrows, 1984; Schmidt, 1993). De eerste drie onderzoeken waren experimented van opzet en gericht op het vaststellen van de effecten wan probleemanalyse. In de latste twee onderzoeken werd de techniek van prorocolanalyse gebruikt om na te gaan of, op basis van recente inzichten verkregen in de cognitieve psychologie, een meer gedetailleerde analyse kan plaarsvinden wan het proces van probleemgestuurd leren.

De centrale vragen van dit proefschrifr kunnen als volgt worden geformuleerd:

"Wat zijn de effecten van probleemanalyse in de kleine groep op her leren van nieuwe informatie in een studierekst?" en "Welke cognitieve processen kunnen worden waargenomen rijdens de probleemanalyse?"

\section{Hoofdstuk 2}

In Hoofdsruk 2 zijn allereerst de theorerische vetklaringen voor de rol van voorkennis bij het leren van nieuwe informatie geinwentariscerd. Hierbij is nict alleen nagegaan welke theorieen de effecten van probleemanalyse in de kleine groep kunnen verklaren. Ook is nagegaan of er talkstructuren bestaan die overeenkomsten vertonen mer problecmanalyse en waarnaar empirisch onderzock is gedaan naar de effecten ervan. Deze verwante taakstructuren zijn te vinden in hec ickstverwerkingsonderzoek, her onderzoek naar coöperatief leren (brainstormen), en het misconceprie-onderzoek. Hoewel er een grote variatie is in onderzoeksdesign ondersteunen deze onderzocken over het algemeen de elaboratie theoric. De elaboratie theorie veronderstelt dat door her genereren van verklaringen in de groep cen 
betere organisatie en bewustwording van deze nieuwe kennis ontstat waardoor deac kennis beter roegankelijk en bruikbar is. Mogelijk altematieve verklaringen voor de effecten van probleemanalyse op her leren van nieuwe informatie zijn de selectiene andachushyoubese en de motivatiehyposhese. Directe empirische ondersteuning voor de elaboratic theoric over probleengestuurd leren is te vinden in het onderzoek van Schmidt. Schmidt (1982) heeft in verschillende experimenten de effecten wan probleemanalyse in de groep op her leren van een studietekst onderzoche en wond dar deze onderwjsaanpak inderdaad een positieve invloed op de cognitics van zijn proefpersonen had.

In dit proefschrift wordt voortgebouwd op eerder onderzoek naar de effecten van problecmanalyse op het leren van nieuwe informatic uitgevoerd door Schmidt (1982). Voor het vaststellen van de effecten van probleemanalyse werden als afhankelijke variabelen gebruike het aantal correct berinwerde proposities van de studietekst, maar daarnaast ook variabelen die te maken hebben met her parroon van de rcall, namelijk het onderscheid in beschrijuende en verklarendeproposities en het annal infercmies in de recall.

\section{Hoofdstuk 3}

In Hoofdstuk 3 worde verslag gedaan van een onderzoek naar de effecten van problemanalyse op her leren (recall) van nieuwe informarie bij beginners en bij gevorderde leerlingen. De beginners waren derdejaars leerlingen in het voorbereidend werenschappelijk onderwijs (VWO), en de gevorderden waren viendeklas leerlingen van herzelfde type onderwijs. De nieuwe informatie die de leerlingen moesten bestuderen betrof een biologie onderwerp, namelijk osmose en diffusie. De beginners hadden deze leerstof nog nie besudeerd, de gevorderden hadden het onderwerp kort voor het experiment behandeld. De veronderstelling in dit onderzoek was dat de effecten van probleemanalyse op het leren van nieuwe informarie bij de beginners sterker zou zijn dan bij gevorderden.

Beide groxpen beginners en gevorderden, werden in weeèn verdeeld. De proefpersonen in de experimentele groep kregen het zogenaamde "bloedcelprobleem" voorgelcgd dat zij in de groep moesten analyseren. De proffpersonen in de controle groep kregen cen niet rekvant probleem. De tak was om voor het gegeven probleen verklaringen te genereren. Na alloop van deze probleemanalyse werd de proefpersonen een reksr over osmose en diffusie woorgelegd, die zij gedurende korte rijd moesten bestuderen. Daana werd hen gevraagd zich alles wat zij zich van de tekst herinneren op te schrijven ("free recall"). Verwolgens werd de procfpersonen gevragd ecr aanvultoets in te vullen.

Uit de resultaten van de frec-recall toets bleek dat probleemanalyse het verwerken en herinneren van de rekst aanzienlijk vergemakkelijkt. Hoewel her verschil tussen de experimentele en de controle groep groter bleek te zijn voor de beginners dan woor de gevorderden ondersteunde de afwezigheid van een significant interactie 
effecr de oorspronkelijke weronderstelling dat er meer leren plaatsvindt bij proefpersonen die een grotere discrepantie ervaren russen wat ze weten en wat ze moeten weten over een onderwerp niet. Uir de resultaten bleek verder dar het experimentele effecr, zoals weerspiegeld in de recall, geheel veroorzaakr werd door de betere verwerking en herinnering wan verklarende informatie. Beschrivende informarie werd nier beter herinnerd als gevolg van de analyse van her bloedcelprobleem. Dit laatste effect was sterker voor de gevorderden dan voor de novieten. Uit de anvultoets bleek wel een significant interacrie-effect tussen de aatrd van de akrivarietak en expertise niveau. De beginners hadden significant meer profijt wan de probleemanalyse dan gevorderden.

De resultaten van dit experiment zijn consistent met her idee dat problecmanalyse een faciliterende werking heeft op her leren wan een relevante studietekst. Verder ondersteunen de resulaten de opvatting dat probleemanalyse de cogniticve processen van de lerende beinvloedt. Probleemanalyse heeft blijkbaar de studenten geholpen de aandacht te richten op de verklarende informatie in de tekst en hen gestimuleerd daartussen relaties te leggen en deze te integreren in de voorkennis. De veronderstelling dat movieten meer zouden profiteren van probleemanalyse is gedeeltelijk bevestigd. De resulaten wan de free recall toets laten echter zien dar ook gevorderden profijt kunnen hebben van probleemanalyse in de groep.

\section{Hoofdstuk 4}

Probleemgestuurd leren is een coöperatieve leersituatie, walarin interactic tussen lerenden centraal staat. De achterliggende idee is dat interactie meer stimulecrt tot her genereren wan meer geẻlaborcerde verklaringen dan wanneer er een individuele probleemanalyse plaarsvindt. In Hoofdsuk 4 wordt een experiment beschreven dat de effecten van probleemanalyse in de groep vergeleek met de effecten van een individuele vorm van analyse van het bloedcelprobleem. Daarnaast werd een controlegroep gevraagd naar hun wook kennis over osmose en diffusie. Proefipersonen in dit experiment waren eerstejaars HBO-studenten. De materialen in onderzoeksprocedure kwamen overeen mer her experiment dat beschreven is in Hoofdstuk 3. De eerste veronderstelling die aan dit experiment ten grondslag lag, was dat de mare van elaboratie door middel wan problecmanalyse in de grocp groter is dan individuele probleemanalyse en dat de mate wan elaboratic door middel van individuele probleemanalyse weer groter is dan de simpele vraag naar voorkennis tak. De tweede veronderstelling was dat hoe groter de mate van claboratie, des te sterker de organisarie en bewustwording wan de kennis en daardoor des te groter de toegankelijkheid wan de kennis.

Uit de resultaten van de free recall toets bleck dat er geen significant verschil werd gevonden tussen de drie verschillende groepen wat betrefr de total antal correct herimnerde proposities. Hoewel de rrend overeenkome met de veronderstekde toename aan correct herinnerde proposities zijn de verschillen klein en valt verder 
vooral de grote standaard deviatie op bij de groep problecmanalyse individueel. Verder is er geen significante interactie tussen treament en type propositie. Bij de resultaten van de aanvultoets bleek wel een significant verschil russen de drie groepen wat betreft de totaal aantal correct herinnerde items uit de aanvultoets. De lineaire component in het effect bleek significant te zijn.

Hootdstuk 5

In Hoofdstuk 5 worde verslag gedaan van onderzoek ruaar de effecten van probleemanalyse in een groep in een leerstofdomein dat complexer van aard is, namelijk dat wan de geneeskwnde. In dir onderzoek werd gebruik gemaakt van proefpersonen die getraind zijn in probleemgestuurd leren. De onderzoeksopzer sloot zoved mogelijk aan bij de onderwijssituatie van de studenten, opdat een zo groot mogelijke ecologische validireit gewaarborgd werd. De vraagstelling van dit onderzock was of de effecten van probleemanalyse in de groep op het leren van nieuwe informatie in een dergelijke siruatic ook gevonden konden worden.

In dit experiment kregen eerstejars medische studenten een probleem over de effecton van een bijensteek voorgelegd dar zij in de groep gedurende 30 minuten moesten analyseren. De controlegroep kreeg een niet relevant probleem. Nadat men in de groep onder begeleiding van cen ouderejaarsstudent (die als gesprekleider optrad) verklaringen voor het probleem had gegenereerd, werd ter bestudering cen studietekst over blocddrukregularie voorgelegd.

De free recall toers gaf de volgende resultaten: Er werd een significant verschil gevonden russen de groepen. Hiemee wordt de elaboratie hypothese bevestigd dat relevante probleemanalyse woorafgaande aan de te leren studietekst, ook in een ecologisch valide onderzoek, leidt tor het beter onthouden van informatie uit die rekst. De veronderstelling dat het effect weer vooral bij verklarende en niet bij beschrijwende proposities zou optreden werd niet bevestigd; evenmin werden significante verschillen gevonden tussen de experimentele groep en de controle groep wat bercf het aan al inferenties. Verklaringen voor het ontbreken wan verschillen russen de twee groepen wat berref het aantal inferenties in de recall werd gevonden in de veronderstelling dat dit effect vooral pas zichtbanr worde na verloop van langere rijd (de inferential-reconstruction hypothese).

\section{Hootdstuk 6}

In Hooflstuk 6 wordt een studie beschreven warin de cognitieve en metacognirieve processen tijdens problecmanalyse in de groep onderzoch werden door de verbale communicatie cussen de groepsleden te analyseren en de daarbij optredende denkprocessen. Het doel van dit onderzock was tweeledig, namelijk na te gaan in hoeverte probleemgestuurd leren conceptuele verandering stimuleer, en om een merhode te ontwikkelen die gevoeliggenoeg is om deze verschijnselen in kaart te brengen. 
Proefpersonen waren een groep tweedejaars studenten geneeskunde aan de Unim versiteit Mastricht. Deze studenten hadden de nodige ervaring met de uirvoering van probleemanalyse in de groep. De groep studenten moesten een casus analyseren die vermeld stond in her blok Pijn, dar onderdeel is van her derde curriculumjaar. De groep studenten analyseerden her probleem gedurende 20 minuten. Deze groepsinteractie werd op video opgenomen in een professionele vidcostudio. Direct na de sessic werden wijf identieke kopieèn wan de mastertape met tijdcodes geproduceerd. Denkprocessen werden onderzocht door middel van een "stimulated recall" procedure. Daarbij werden de deelnemers na afloop van de probleemanalyse gevraagd om, gestimuleerd door cen video-opname van de probleemanalyse, alles wat zij tijdens de analyse hadden gedacht te verbaliseren. Verbatim transcripten van zowel de verbale interactie in de groep als de stimulated recall werden geanalyseerd.

De resultaten van dit onderzoek wezen uit dat de verbale interactie in de groep slechts de top toont van de ijsberg van cognitieve en metacognitieve processen waarop het is gebaseerd. De verbale interactie in de groepsdiscussie betrof hoofdzakelijk theorievorming (het geven van verklaringen voor de in her problem beschreven verschijnselen) en in mindere mate data-exploratie en meta-redeneren. Stimulared recall van het denkproces rijdens deze discussie echter leverde meer en ook unieke informarie over hyporhese evaluatie en meta-redeneren. In de prorocollen gestimuleerd door de stimulated recall procedure kon het proces van conceptuele verandering zichtbar gemaakt worden. De manieren waarop met anomalieën werd omgegaan kon worden beschreven evenals de woorwarden die bepalen hoe studenten met deze anomaliè̈n om gaan. Deze resultaten suggereerden dat de methode adequat is woor het in kaart brengen van conceptucle verandering tijdens probleemanalyse.

\section{Hoofostuk 7}

In Hoofdstuk 7 word verslag gedaan van onderzock met behulp wan de modrode wan probleemanalyse nar de aard van misconcepties van beginners en gevorderden op het gebied van osmose. Doel van dit onderzock was na te gaan of mer behulp van de methode probleemanalyse deze misconceptics geidentificerd kunnen worden. Probleemanalyse in de kleine groep vraagt van de studenten op basis van een probleembeschrijving verklaringen te genereren door middel van discussic. De weronderstelling is dat door het construeren van verklaringen in de groep de voorkennis geacriveerd wordr en hierop geelaboreerd word on dat darmee de voorkennis en de kenmerken daarvan explicier gemakt wordt.

Proefpersonen waren een groep derde klassers wwo, cen groep wierde klassers wwo en een groep eerstejaars hbo studenten. Her betrof dezelfde proefpersonen als die deelnamen aan de in Hoofdsuk 3 en Hoofdsruk 4 beschreven experimenten. In keine groepen analyseerden de proefpersonen hee aan hen woorgelegde blocded- 
probleem. Van de verbale interactic tussen de groepsleden werden protocollen gemaakn die de basis vormden voor meer gedetailleerde analyses.

Uit de resultaten wan dit onderzock bleek dat probleemanalyse tor een sterke activarie van de voorken mis stimuleerde. Het aantal verklaringen en de grote variatie daarin (vooral bij beginners) illustreerde dit. Deze zelf gegenereerde verklaringen laten zien dat heel werschillende kennisgebieden door probleemanalyse worden geacriveerd, wariërend van ervaringskennis tot schoolkennis. Naast deze variatie aan verklaringen waren er ook een aantall overeenkomsten. Zo bleek dat er accurate, maar ook regelmatig terugkerende inaccurate verklaringen zijn voor her proces van osmose. In de protocollen waren overeenkomsten aan te geven wat berreft vorm en inhoud van de verklaringen. De inaccurate verklaringen zijn begrijpelijk bij de beginners angezien het hier geconstrueerde misconcepties zijn, maar ze komen ook voor bij gevorderde studenten. Uit de onderzoeksresultaren bleek dat probleemanalyse in ieder geval die misconcepties blootlegt die andere onderzoekers met verschillende andere onderzoeksmethoden ook hadden gesignaleerd. Daarnast liet deze onderzoeksmethode nog een nieuwe misconceptie zien. Het feit dat misconcepties voorturen ondanks onderwijs op dat gebied bleek uit de gevonden misconcepties bij gevorderden.

\section{Hoofdstuk 8}

In dit laatste hoofdstuk worden de resultaten van de studies in dir proefschrif geinterpreteerd wanuit de eerder gegeven elaboratietheorie. De beperkingen van dit onderzock betreffen vootal de generalisecrbaarheid van de onderzoeksresultaten en de beperkingen van het onderzoeksdesign. Er worden suggesties voor verder onderzock gegeven. Deze hebben onder andere betrekking op onderzoek naar de cogninieve processen tijdens het probleemgestuurd leerproces. Verder worden er suggesties gedaan tot verbetering van het onderzoeksdesign om nog beter aan te sluiten bij het problecmgestuurde leerproces. Anderzijds wordt gesuggereerd om na te gaan of de onderzoeksresulaten generaliseerbaar zijn bij leerstof van verschillonde mate van complexiteit voor lerenden en bij leerlingen en studenten uit verschillende srudisiaren.

Tenslote worden de implicaties van deze seudies voor het onderwijs besproken. Dere implicaries hebben vooral berekking op her oprimaliseren wan deze fase van problemgestuurd leren. Verschillende factoren worden genoemd, zoals de rol van de tutor woor her realiseren van voldoende elaboratie tijdens de probleemanalyse en de kwalitcit wan de problemen, die als startpunt voor een probleengestuurd lcerproces dienen. 


\section{Summary}

\section{Introduction}

Problem-based learning in small groups is a learning method based on a construcrivist approach to the leaming process and on the importance of interaction to promote learning. This dissertation focuses on the initial stage of problem-based learning, the problem analys stage, which precedes the actual study stage. Prob$1 \mathrm{~m}$ analysis is a stage in which students jointly generate explanations for a problem presented to them. This is a merhod, which stimulates learners to acrively relare any new information to be learne to the knowledge they already have. This is also called elaborating. The aim of the sudics in this dissertation is to provide a empirical support for the basic claim made with respect to problem-based leaming, i.e. that problem-based learning leads to more effective learning and remembering of new information (Barrows, 1984; Schmid, 1993). The first three studies had an experimental secup and focused on deternining the effects of problem analysis. The last two studies used the technique of protocol analysis to find out whether insights recently acquired in cognitive psychology could be used to make a more detailed analysis of the process of problem-based learning.

This dissertation deals with the following key questions: "What are the effects of problem analysis in a small group on learning new information in a study text?" and "Which cognirive processes can be observed during problem analysis?"

\section{Chapter 2}

Chapter 2 makes an irventory of the rheorerical explanations of the rolc of prior knowledge in learning new information. This yiclds the elaboration theory as the primary theory to explain the effeces of generating explanations in small groups on learning new information. Not only was it investigated which theory could best explain the effects of problem based learning in small groups. It was also investigated if rasks and cask seructures could be identified that are related oo problem analysis and if research in these domains could support our theories pertaining to the effects of problem analysis. Such related task strucures can be found in text processing studies, research of comperative leaming (brainstorming), and misconception research. Although the design of these studies varies greatly, the studies generally support the elaboration theory. The elaboration weory assumes that generating explanations in a group creates an onhanced organisation and awareness of new knowledge, making the latrer more accessible and applicable. Possible alter- 
native explanations for the effecrs of problem analysis on leaning new information include the selective atuention bypowesis and the motivation bypothesis.

Direcr empirical support for the theory of problem-based learning can be found in the research done by Schmidt. Schmidr (1982) has carried out a number of experiments to study the effects of problem analysis in groups on learning a study text. He found that this educational approach in fact has a positive effect on cognition in test subjects.

This dissertarion elaborates on earlier research of the effecrs of problem analysis on learning new information carried out by Schmidt (1982). To determine the effects of problem analysis, the dependent variables used included the number of correctly remembered propositions of the study text, but also wariables relating to the recall pattern i.e., the difference between decriptive and explanatory propositions and the number of inferences in the recall.

\section{Chapter 3}

Chaprer 3 contains a report of research concerning the effects of problem analysis on learning (recall) of new information in novices and in advanced subjects. Novices were third-year pupils of pre-university education (PUE), while the advanced subjects were fourth-year pupils of the same type of education. The new information that the pupils were expected to study concerned a topic from the field of biology: osmosis and diffusion. The nowices had not studied this topic before, whereas the advanced subjects had dealt with this topic not long before the experiment. "The supposition in this study was that the effects of problem analysis on leaming new information in nowices would be greater than in the advanced subjecrs.

During the experiment, the subjects in the experimental group were given the soalled "blood cell problem" to analyse in the group. The subjects in the control group were given an irrelevant problem. The task ser was to generate explanations for the problem presented. Afrer this problem analysis stage, subjecrs were given a texc on osmosis and diffusion, which they had to study for a short rime. They were then asked ro write down all they could remember of this text ("free recall"). Subsequently, the subjects were asked to fill in a completion rest.

The results of the free-tecall rest showed that problem analysis greatly enhanced the processing and remembering of the text. Although the difference berween the experimental group and the control group appeared to be greater among the novices than among the advanced subjects, the absence of an interaction effect did not support the origina! supposition that more learning rakes place in test subjects who experience a greater discrepancy between what they lknow and what they should know. The results also showed that the experimental effect, as reflected in the recall, was caused envirely by the processing and remembering of explanatory information. Descriptize information was not remembered any better as a result of 
the analysis of the blood cell problem. The latter effecr was grearer in the advanced subjects than in the novices. The completion test, however, showed a significant interaction effect between the nature of the activation task and the level of expertise. The novices benefited significanty more from problem analysis than the advanced subjects did.

The results of this experiment are consistent with the idea that problem analysis has a facilitating effect on learning a study text that is relevant for the problem. The results also support the idea that problem analysis affects the cognicive processes of learners. Problem analysis apparently helped the pupils to focus on the explanatory information in the text and helped them create relationships berween different parts and to integrate the information in the existing knowledge. The supposition that novices would benefit more from problem analysis was confirmed to some extent. The results of the free-recall test, however, show that advanced subjects may also benefit from problem analysis in groups.

\section{Chapter 4.}

Problem-based learning is a co-operative learning situation, based on the interaction between learners. The idea behind this is that interacrion promotes the generation of more elaborated explanations than would be the case in individual problem analysis. Chapter 4 describes an experiment which compared the effects of problem analysis in a group with the effects of an individual form of analysis of the blood cell problem. Ar the same time an other control group was asked after its previous knowledge of osmosis and diffusion. The test subjects in this experiment were first-year HVE students. The materials and study procedures used corresponded with those used in the experiment described in Chapter 3. The first suppasition on which this experiment was based, was that the degree of elaboration by means of problem analysis in a group would be greater than in the case of individual problem analysis, and that the degree of elaboration by means of individual problem analysis in turn would be greater than a mere question as to previous knowledge. The second supposition was that the greater the degree of claboration, the stronger the organisation and awateness of the knowledge would be. and hence the greater the accessibility of this knowledge.

The results of the free-recall test showed that there was no significant difference berween the three different groups as to the total number of correctly remembered propositions. Although the trend corresponds to the increase of the number of correctly remembered propositions assumed on the basis of the elaboration hypothesis, the differences are small, and a striking aspect is the large standard deviation in the group who performed individual problem analysis. In addirion, there was no significant interaction berween treatment and type of proposition. The results of the completion rest, on the other hand, showed a significant difference be- 
ween the thee groups as to the not number of correcty remembered items in the complerion rest. The linear component in this ffect proved significant.

\section{Chapter 5}

Chapter 5 contains a repor of research done into the effect of problem analysis in a group within a subject field which is more complex, i.e. from the field of Medicine. In this study, use was made of test subjects who had been trained in the application of problem based learning. The serup of the study corresponded as much as possible to the learning situation of the student, so as to guarantee the greatest possible cological walidey. The question dealt with in this study was whether the effects of problem analysis in a group on learning new information could also be observed in such a siruation. The supposition was drat effecs of problem analysis should occur because the fact that the subjects were rained should lead to enhanced interacrion beween the sudents, and hence to greater elaboration.

In this experiment, first-ycar sudents of Medicine were given a problem on the effects of a beesting, which they were asked to analyse in the group for a period of 30 minutes. The control group was given a non-relevant problem. After explanations for the problem had been generated in the group, under the supervision of a sentor student (who acted as discussion leader), a text on blood pressure regularion was presented, which the subjects had to sudy.

The frec-recall rest yielded the following results: a significanc difference was found between the group dealing with the bee sting problem and the one dealing with the concrol problem as to the rotal number of correctly remembered proposicions. This confirms the elaboration hypothesis that problem analysis prior to learning the study text also leads to better remembering of the information from the text in an ecologically valid study. The supposition that the effect would occur primarily in the explanatory and not in the descriptive propositions, was not confirmed; neither were any significant differences found berween the experimental group and the control group as to the number of inferences. Explanations for the absence of differences beiween the wo groups with respect to the number of inferences during recill were found in the inferental reconstruction hyporhesis.

\section{Chapter 6}

Chaprer 6 describes a study in which the cognitive and metacognirive processes during problem analysis in the group were investigated by analysing both the verbal communications between members of the group and the corresponding mental processes. The aim of this study was rwofold: to find out to what extent problem-hased learning promores conceptual changes, and ro develop a method which is sensitive enough to reord such phenomena.

Test subjecs came from a group of second-year students of Medicine of the University of Marstriche. These students had considerable experience in the area of 
problem anallysis in groups. The group of students was asked to analyse a case presented in the study block Pain, which is part of the third year of the study of Medicine. The group of studenrs analysed the problem for a period of 20 minutes. This group interaction was recorded on videotape in a professional recording studio. Immediately after the session, five identical copies of the master tape were produced with rime codes. Mental processes were studied using a "stimulated recall" procedure. This meant that the parricipants were asked after the problem analysis stage ro watch the video recording as a stimulus for stating every thing they remembered to have thought. Verbatim transcripts, both of the verbal inceraction in the groups and of the stimulated recall, were analysed.

The results of this study proved that the verbal interaction in the group only shows the rip of the iceberg of the cognitive and metacognitive processes on which it is based. The verbal interacrion in the group discussion mainly concerned the forming of theories (giving explamarions for the phenomena described in the problem), and to a lesser extent data exploration and merareasoning. Stimulated recall of the mental process during this discussion, however, yielded more as well as unique information conceming hypothesis evaluation and metareasoning. In the protocols prompted by the stimulated recall procedure, the process of conceptual change could be made visible. The way in which anomalies were dealt with could be described, as well as the conditions that determine how students deal with such anomalies. These results suggested that the method can in fact be used to register conceptual changes during problem analysis.

\section{Chapter 7}

Chapter 7 reports on a study of the nacure of misconceptions in novices and advanced subjects in the field of osmosis, using the method of problem analysis. The aim of this srudy was to determine whether it was possible to use the method of problem analysis to identify these misconceptions. Problem analysis in small. groups demands that students generate explanations on the basis of a problem description by means of discussion. The supposition is that constructing explanacions in the group activates prior knowledge and that subjects daborate on this, rhus making explicit this prior knowledge and its characteristics.

The test subjects were a group of third-year pupils of PUt, a group of fourth-ycar pupils of PUE, and group of first-year HVE students. These were the same lest subjecrs who also parricipared in the experiments described in Chapters 3 and 4 . In small groups, the subjects analysed the blood cell problem presented to them. The verbal interaction berween the group members was recorted in protocols, which constituted the basis for more derailed analyses.

The results of this study showed that problem analysis triggered a powerful activat tion of prior knowledge. The number and the great varicty of explanations illustrate this (in particular in novices). The self-generated explanations show that 
problem analysis activates a wide variety of knowledge areas, from practical experience vo school knowledge. In addirion to this waration, there were also a number of similarities. It appeared that there were accurate, but also regula rly recurring inaccurare explanations for the process of osmosis. It was also possible to point to similarities regarding the form and contents of the explanations. The inaccurate explanations are understandable in the novices, because these are construed misconceptions, but they also occur in advanced subjects. The test results showed that problem analysis identifies at least those misconceptions that other researchers, using differen research methods, had also observed. In addition, this research method also yielded a new misconception. The fact that misconceptions persevere in spite of education in this area, appeared from the misconceptions in the advanced subjecrs.

\section{Chapter 8}

In the last chapter, the results of the studies in this dissertation are interpreted on the basis of the above-mentioned elaboration theory. The limitations of this study concerned in particular the ability to generalise the study results and the restrictions of the study setup. Suggestions are made for furcher research. These include additional research of the cognitive processes during the problem-based learning process. Suggestions are also presented for improvement of the sudy setup to adape more to the problem-based learning process. On the other hand, it is proposed to investigate wheher the study results can be generalised in the case of subject matter of varying degrees of complexity for learners and in pupils and students from different study years.

Lastly, the implications of these studies for education are discussed. These implications concern in parricular the optimisation of this stage of problem-based learning. Various factors ate mentioned, including the role of the rutor in bringing abour sufficien elaborarion during problem analysis and the quality of the probtems used as the starting points for a problem-based learning process. 


\section{Literatuur}

Alba, I. W.. \& Hasher, L. (1983). Is memory schematic. Pychologial Bulerm, 932), 203-231. Alexander, P. A.. Kulikawich, J.M. \& Schulze. S.K. (1994). How subject-manter knowledge affects recall and inreresr. American Edwrational Researd fonpal, 312), 313-337.

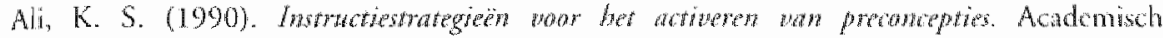
Proefschrife Katholicke Universineit Braban, Helmond: Wabra

Alvermann, D. E., \& Hagne, S.A. (1989). Comprehension of comnterintuive seience text: Effects of prior knowledge and text structure. Jowmal of Edhational Resand? $82(4)$, $197-202$.

Alvermann, D. E., \& Moore, D. W. (1991). Secondaty sthool reading. In R. Barr, K. M. Kamil. P.B. Mosenthal, 8. P.D. Pearson (Eds), Handbook of reading wermb (Vol. 11. pp. 95 I-983). New York: Longman.

Amir, R. Frank1, D.R., \& Tamir, P. (1987). Justifications of answers a mulciple choice iachns as a means for idencifying misconceprions. In J. Novak (Ed), Procedings of ilke scond incemational seminar "Misconceptions and educational stategies in science and mathemarics: Vol. I. (pp. 15-25), Ithaca: Comell University.

Anderson, R. C. (1977). The notion of schemata and the educarionat enterprise: Genetal discussion of the conference. In R. C. Anderson, R.). Spiro, $\alpha$ W.E Montague, (Eds.). Schooling and the acquisition of knowledge. Hillsdate. NJ: Erlbaum.

Anderson, R. C., \& Pearson, P.D. (1984). A schema-heorevic view of basic processes in reading comprehension. In P. D. Pearson (Ed), Handbook of reading restarch (pp. 255-294), New York: Longman.

Anderson, R. C. (1984). Some reflections on the acquasition of knowledge. Edrational Researcher, $13,5-10$.

Barrows, H. S., \& Tamblya. R. (1980). Problen based leaming: An appraded to whedral eduation. New York: Springer.

Barrows. H. S. (1984). A specific problembased, self-directed loarsing method designed to wath medical problem-solving skilk, and enhance knowledge retomion and reall. In: H.C.

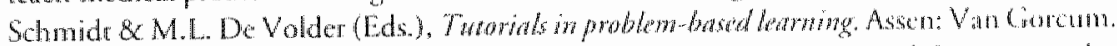

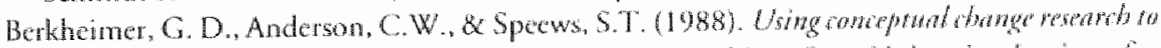

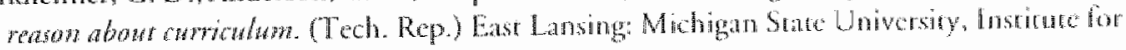
Rescarch on Teaching.

Beryme, D. E. (1978), Curiosity and learning. Motwaton and Emoth\%, 2, 97-175.

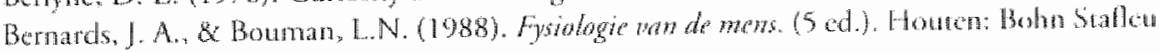
Van Loghum.

Berne. R. M. \& Levy, M.N. (1992). Cardionacular Jhysology (6 ad.) St Louis: Mosby.

Biclacayc, K, Pirolli, P.L., \& Brown. A.L. (1995). Trabing in sulfexplanation and self-regulation stategies: Investigaring the effects of knowledge acquision activities on problem solving. Cogrition and Instraction, $13(2), 221252$.

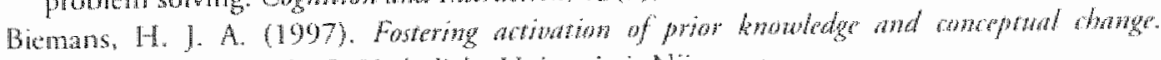
Academisch proffelurife, Katholicke Universitcit Najmegen. 


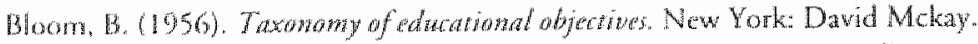

Boshuzen. H. P. A., Schmidr, H.G. \& Coughin, L.D. (1987). On-Line representation of a

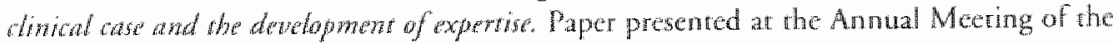
Educational Research Asseciatom. Washington, DC.

Bransford, ]. D., \& Johnson, M.K. (1972). Contextual prerequisites for undersanding: Some

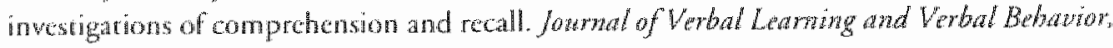
$11,717-726$.

Brent Gallupe, R., Bastanutr, L.M. \& Cooper, W.H. (1991). Unblocking brainstoms.

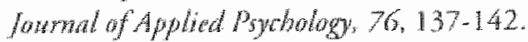

Brower, W. F, \& Nakamura, G.V. (1984). The nature and funcrions of schemas. In R. S. Wyer

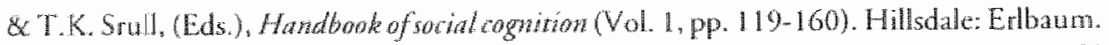

Brower, W. F. (1987). Schemas versus menal modeds in human memory. In P. Morris (Ed.), Modeling Cogrivion (pp. 187-197). London: John Wiley.

Bromage, B. K., \& Mayer, R.E. (1981). Relationstrip between what is remembered and crearive problem solving performance in science leaming. foumal of Edwational Pyothology, 73(4). 453-461.

Brown, A. L., B Pancsar. A.S. (1989). Guided, cooperative learning and individual knowledge acquisition. In L. B. Resnick (Ed). Knowing leaning and instuction (pp. 393-451). Hillsdalle, MJ: Entbaum.

Champagne, A. B., Klopfer, L.E., \& Gunstone, R.F. (1982). Cognitive research and the design of scicnce instruction. Edactitural Pychologist, 17(1), $31-53$.

Champangne, A. B., Gubstone. R.F., \& Klopfer, L. E. (1985). Instructional consequences of students' lenowledge about physical phemomena. In L. West \& L. Pines, (Eds), Cagwitive

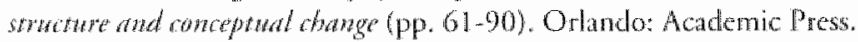

Champagnc, A. B. \& Bunce, D.M. (1991). Learning-theory-based science teaching. In S. M. Gilyn, R.H. Yeany, \& B.K. Bricuon (Eds.), The pychology of leamaing soiener (pp. 21-41). Hillsdale, N]: Erlbaum.

Chi, M. T. H. Glase, R. \& Fiarr, M.J. (1989). The nafwe of expertie. Hillsdale, NJ: Erlbaum.

Chi, M. T. H. Bassols, M. Lewis, M.W. Reimann, P., B Glaser, R. (1989). Selfexplanations: How students study and use cxamples in learning to solve problens. Cognitive Science, 13, $145-182$.

Chicsi. H. L., Spitich, G.J., \& Voss, J.F. (1979). Acquisition of domain-related information in

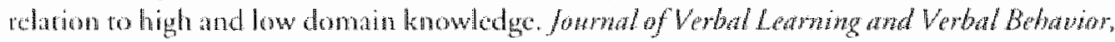
$18,257 \cdot 273$.

Chimn, C. A., Berewer, W.F. (1993). The rolo of anomalous dara in knowledge acquisition: A theoretical fomaworte and implications for science instrucrion. Rewion of Edwational Resend $63,1-40$.

Clement. I. (1989). Leaming wa nodal anstruction and cricism. In J.A. Glover, R.R. Ronnin, 8 C.R. Reynolds (Eds). Handbook of Cratity (pp. 341-382). New York: Plenum Press.

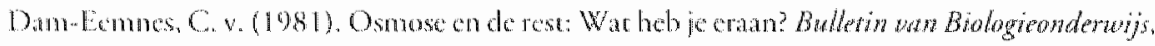
31. 48.53 .

Dawsm Sanders, B. K. Fotowitch, P.J., Couslon, R.L. \& Steward, D. (1987). The curren "top 20 "hirs: Biomedical concepts all medical seudenes need to understand. Paper presented wt the Annual Mecting of the Anerican Educational Rescarch Association, Washington, D.C. 


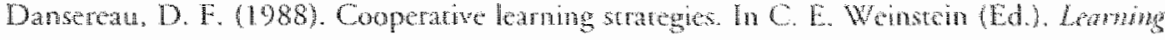

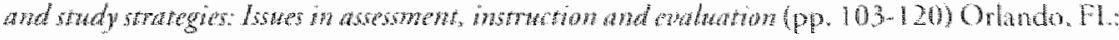
Academic Press.

De Grave, W. S., Schmidr, H.G. Belien, J.J., Mous, JH.C., De Walder, M.L.. \& Konkhots.

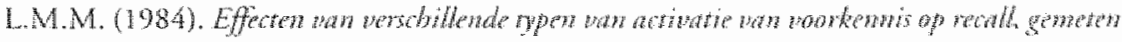
met en adnuthors. Paper gepresencerd op de Onderwis Rescanth Dagen. Tilburg.

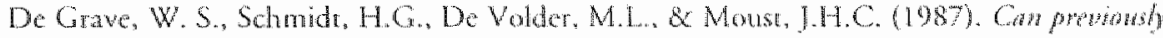

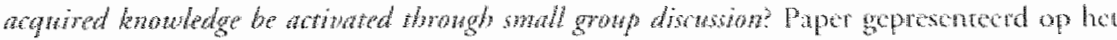
jadrlijks congres van de American Educaromal Research Asociation. Wakingron, DC. April. Educarional Resontces Information Center(ERIC), ED 321712.

De Grave, W. S. \& Frins, P. (1993). Schematiseren als studichardigheid bi problemgesturd leren. Velon Tidsorift waor Lemen Opleiders, $15(1), 42-47$.

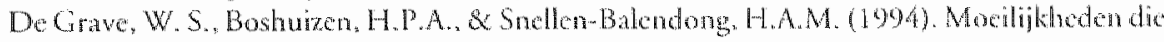

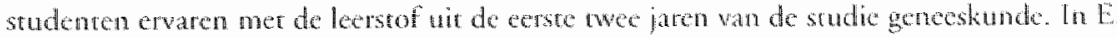

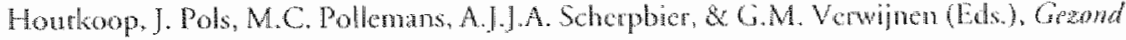
Onderwijs Congres $3(p p .261-267)$, s Gravenhage: Havbeck.

De Grave, W. S. Boshuizen, H.P.A., \& Schmide, H.G. (1996. Problem based leaming.

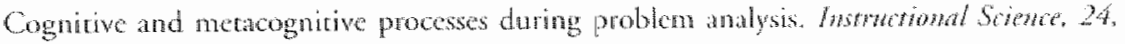
$321-341$

Dieh, M., \& Sroebe, W. (1987). Productivicy loss in brainstorming groups: Towards a

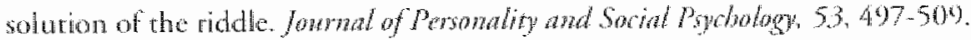

Dreyfus, A. \& Jungwirth, E. (1988). "The cell concept of torh graders. Curricular expectantins

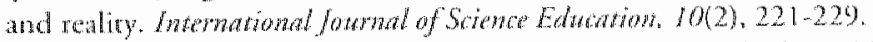

Dreyfus, A., Jungwirch, E.. \& Eliovitch, R. (1990). Applying the "cognitive conthice" stratrgy

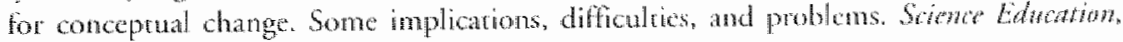
$74(5), 555-569$.

Driver, R., Guesne, E, \& Tiberghien, A. (1985). Some feartues of children's deas and their

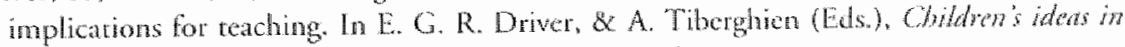
science (pp 193-201). Philladelphia: Open University Press.

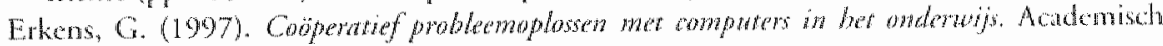
Proelschrift. Rijksnniveriteit Utrednt. Uerechr: Brouwer.

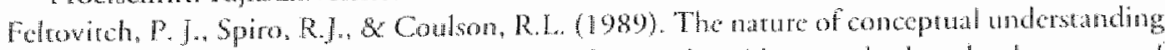
in bomedicine: The decp strucenre of complex idcas and the dewelopment of

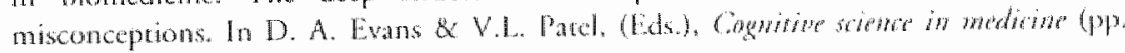
113-172). Cambridge MA: MIT Press.

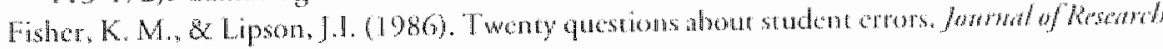
in Scance Thathing, 2369, 783-803.

Friedler. Y., Amir. R., \& Tamir, P. (1987). High selyool stedentedificulace in understanding

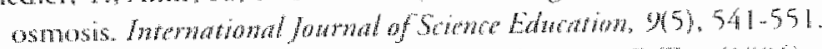

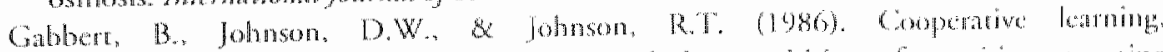

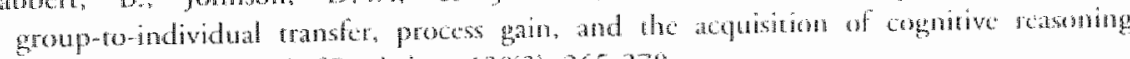

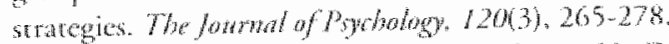

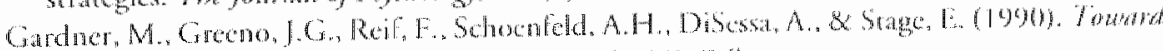

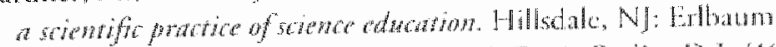

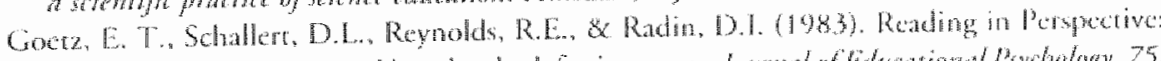

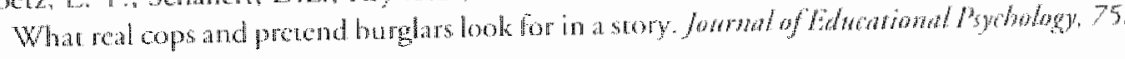
$500-510$. 
Gunstone, R. F. (1989). Learmers in science educaton. In F. Fensham (Ed), Development and dilewnas in science eduation (pp.73-95). London: The ralmer Press.

Guyton, A. C. (1991). Medical Physiology. (8 ed). Philadelphia: Saunders.

Guzari, B. J., Snyder, T.E. Glass, G.V., \& Gamas, W. 5. (1993). Promoring concepual change in science: A comparative meta-analysis of instructional interventions from reading education and science education. Reading Resterth Qtudrerly, 28(2), 117-159.

Hamiton, $\mathbb{R}$ (1989). The effers of leamer-generated elaborations on concept lcaming from prose. Jourwal of Experimemal Edacation, $205-216$.

Hashwch. M. (1986). Toward an explanation of conceprual change. European Jownal of Scince Education, 8(3), $229-249$.

Hashweh, M. (1988). Descriprive studies of scudencs conceptions in science. Jownd of Resedxds in Science Teaching 25(2), 121-134.

Hassebrock, F., \& Pretula, M.J. (1992). A protocol-based coding scheme for the analysis of medical reasoning. Whernational Joumal of Man-Mactine Studies, 37, 613-652.

Hill, G. W. (1982). Group wersus individual performance: Are $\mathrm{N}+1$ heads berter than one? Pyolowlogical Buldetin. 9/(3),517-539.

Johnson, D. W., \& Johnson, R.T. (1989). Cooperation and competision. Edina: Interaction Boor Company.

Johnstone, A. H. \& Mathmoud. N.A. (1980a). Isolaring ropics of high-perceived difficulty in school biology. Jourmal of Biological Edacation, 142), 163-166.

Johnsronc, A. H., \& Matmoud, N.A. (1980b). Pupil's problalems with water potental. Jourmat of Biological Education, 14(4), 325-328.

Kanselaar, C., Linden, J.L. van der, \& Erkens, G. (1997). Samenwerkend leren in hee studiehuis. In Studiebsis in de stexgers, 3. Tilburg: Meso Consult B.V.

Kapreyn, M. (1990). The function of organizational levels in biology for describing and planning biology education. In P. L. Lijnse, P. Lichc, W. de Vos, \& A.J. Waarloo, (Eds.),

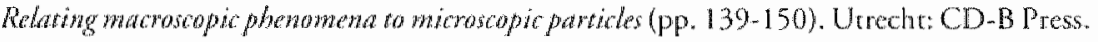

King, A. (1992). Faciliating elaborative learning through guided student-generated questioning Eatuational Psychologist, 27(1), 11.1-126.

King, A. (1994). Guiding knowledge construction in the classroom: Efects of teaching children how to question and how ro explain. Anerican Edacational Research Jommal, 31(2), 338-368.

Kintgen, E. R. (1983). The preneptron of poery. Bloomington: Indiana University Press.

Kintsch, E., \& Kintsch, W. (1995). Strategies to promote acrive leaming from texte Individual differences in background lanowledge. Swiss jownt of Psyobalogy, 54(2), 141-151.

Kinsch, W. (1993). Information accretion and reduction in text processing: Inferences. Discouse trocesser, 16, 193-202.

Kintsch, W. (1994). Tex comprehension, memory, and tearning. American Pyobologist, 49(4), 2944303

Lamberigrs, R. J. A. G., Verhagen, E.J., Gerris, J.R.M., \& Campbell, H.W. (1986). Cooperanieve lecrgroepen in perspectic van onderzock. Pedagogische Studien, 63, 262-274.

Lamm. H., \& Trommedort, G. (1973). Group versus individual performanoe on tasks requiring ideational proficiency brainstoming): A review. Enropean foumal of Sacial Pyolotoge, 3(4), 361-388.

Langer. J. A (1981). From thoory to practice fournal of Reading, 25, 152-156.

Langer, J. A. (1984). Examining background knowledge and text comprehension. Reading Reand Qunterly. 19(4), 468-481. 
Levin, 1. R. (1988). Elaboracion-based leaming strategies: Powerful theory = pownth application. Comemporary Edrational Pybology, 13,191-205.

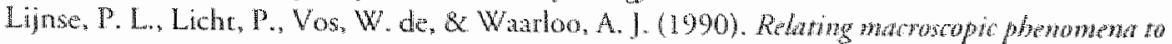
microscopic partides: A cental problem in secondary science edwation Uneche CD B Press.

Linden, J. L. wan der (1987), Samenwetken en leren in her onderwijs. In: J.H. Boontman. \& J.L.

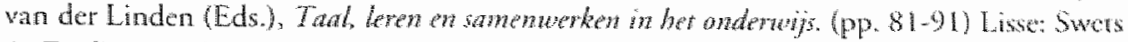
\&. Zeitlinger B.V.

Linn, M. C. (1986). Science. Cognhrian and Thatmion, 155-204.

Loewenstein, G. (1994) The psychology of curiosity: A review and reinteprecation. Poydological Bullewh, 116,75-98.

Machicts-Bongaers. M. (1993). Moblizing prior knowledge in text pracensing. Academisch Proetschrife, Universiteit van Limburg. Masstricht.

Marek, E. (1986). Understandingx and misunderstandings of biology concepts. The Amerom Biology Teabler, 48(1), 3740 .

Mayer, R. E. (1980). Elaboration rechniques that incrase the meaningfulness of technical text: An experimental test of the learning strategy bypotheses. fouchat of Edtuctional Psychology. $72(6), 770-784$.

Mayer, R. E. (1985a). How to analyze science prose. In B. K. Briton \& I.B. Back (Eds), Underatandisg expository texo (pp. 305-313). Hillsdale, N): Erlbaum.

Mayer, R. E. (1985b). Strucumal analysis of science prose: Can we increaso problem-solving performance? In B. K. Britron \& J. B. Black (Eds), Undersanding exposithy tex (pp. 65-87). Hillsdale, NJ: Erlbaum.

Mayer, R. E. (1987). Instructional variables that inthence cognitive processes in teading, In B. K. Briton \& S.M. Glynn (Eds.), Executine commol processes in reading (pp. 201-216). Hillsdale, NI: Erlbaum.

Mayer, R. E. (1989a). Models for undersanding. Revitw of Edtatatonal Reserwo, $59(1), 43-64$,

Mayer, R. E. (1989b). Systemanic thinking fostered by illustrations in seicntific text. formal of Edwcational Psyctology, 81(2), 240-246.

Mayer, R. E. (1995). A second look at increasing the understandability of scientifec text. The Journal of Compater Doctmontation, 19(3),45-50.

Mayer, R. E. (1996). Learning strasegies for making sense out of exposirory rext: The SOI model for guiding three cognirive processes in knowledge construction. Edwationt Pyotology Revieu, 8(4), 357-371.

Madostey, M. (1983). Nave theorics of morion. In D. Gontner \& A. Stcwens (Ed.). Mental models (pp. 299-324). Hillsdale, NI: Eribaum.

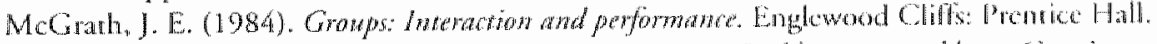

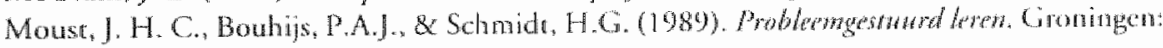
Wolters Noxdhoff.

Mullen, B., Johnson, C. \& Salas, E. (1991). Producrivity loss in lbranstoming groups: A meta analycic integration. Busic and Applied Soctal fsychology, 12(1), 3-23.

Murray, D. L. (1983). Misconceprions of ormosis. In H.Hetm \& J. D. Nowak (Eds). Procectings of the international seminar "Misconceprions in science and mathematics" (p. $428-433)$. Irhaca. NY: Conell University.

Norman, G. R. S., \& Schmide, H.G. (1992). The psychological basis of problicm based lcarning: A review of the evidence. Acadernis Medicine, $67,557.565$

Odom. A. L. (1995). Secondary \& college biology sudents' misconceptions about differion \&

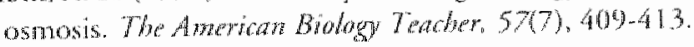


O'Donndl, A. W. \& O Kelly. J. (1994). Leaning from pers: Beyond the rhetoric of posinwe

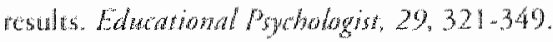

ODonnd1, A. M. D., \& Danserau, D.E. (1992). Scripted choperarion in sruden dyads A mothod for analyong and enhancing academic learning and performance. In $R$

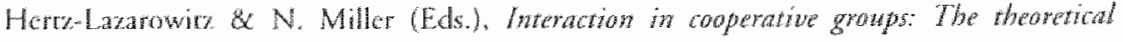
analomy of group lowning (pp. 120-144). New York: Cambridge University Press.

Osborn, A. F. (1957). Applied Mnagindtion. New York: Charles Sribner and Sons.

Osman, M. E. \& Hannafin, M.J. (1994). Effects of adwance quesrioning and prion knowledge

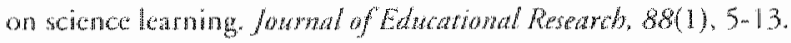

Peck, I. (1982a). Wffects of mobilizarion of prior knowledge on free recall. Jourrat of Experimental Pychology. $8(6), 608-612$.

Peckl, J, Bosch, A.B. van den, \& Kreupeling, W. ). (1982b). Effect of mobiliaing prior knowledge on learning from rext. fowm of Ldacational pychology. $74(5), 771-777$.

Perferi, C. (1985). Readabilty and leaming from wext. (Tech. Rep.) Pictsburgh: Larning Research and Dewelopment Center.

Pekkins, D. N. \& Simmons, R. (1988). Pacterns of misunderstanding: An integrative model for scionce, math and programming. Reyiew of Educatonal Resertech, 58(3), 303-326.

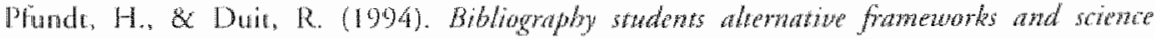
edenatom. (4 ed.). Kicl; Insticur für dic Pidagogik der Naturwissenschafen.

Pichert. J. W. \& Anderson, R.C. (1977). Taking differen perspecrives on a srory. Journal of Edritional Mydhology, 69, 309-315.

Prawat, R. (1989). Promoting access to knowledge, strategy and disposition in studentes: A research synthesis. Review of Eduational Reserd, $59(1), 1-41$

Pressley, M.. MeDantel, M.A., Turnure, J.E., Wood, E., \& Ahmad, M. (1987). Gencration and precision of elaboration: Effects on intentional and incidental learning. Joumal of

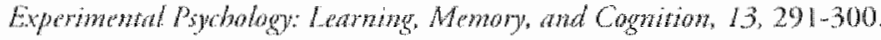

I'ressley, M., Tanembann, R. McDaniel, M.A., \& Wood, E. (1990). What happens when university students try to answer prequestions that accompany textbook material?

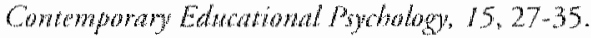

Pressley, M. Wood, E. Woloshyn, V.E., Marnion, V., King, A., \& Menke, D. (1902). Encouraging mindful use of prior knowledge: Atrempting to construct explanatory answers

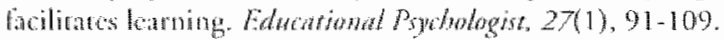

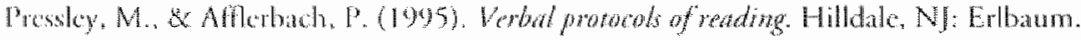

Reder, L. M. (1980). The role of chaboration in the comprehension and retencion of process $A$

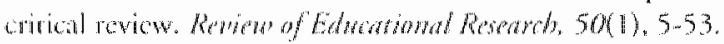

Redter. L. M. (1985). Techniques avalible to suthor, teacher and reader to improwe retention of

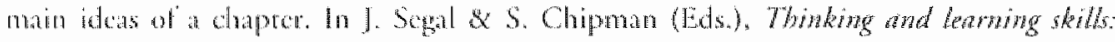

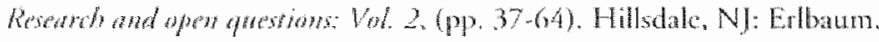

Reter, L. M. Charney. D.H. \& Morgan. K.I. (1986). The role of elabotacions in leaning at

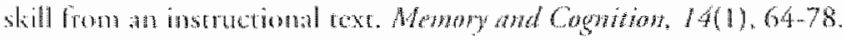

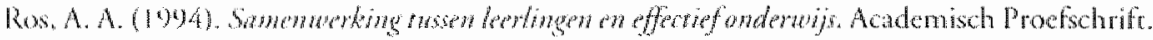
Unoweriteir Ginomingen: RION.

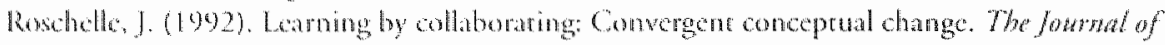

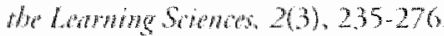

Rothkopf. E. Z. \& Ballingon. M.) (1974). Coal guided teaning for rext: Inferring a descriptive processing model from inspection rimes and cye movements. Joupal of Edhotional Fischolegy. $71,310-327$. 
Rumelhart, D. E. \& Noman, D.A. (1978), Accretion, aning, and restrucuring "Thre mades

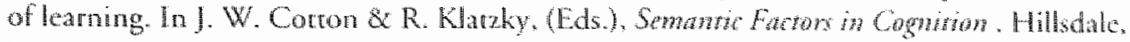
NJ: Ertbaum.

Rumethare, D. E. (1984). Schemara and the cognirve system. In R. S. Wyer \& T.K. Srull, (Eds.), Handbook of rocial cognition (pp. 161-188). Hillsdale: Erilsam.

Sahari. M. (1997) Elaborarion as a rexe-processing stategy: A meramalytic neviow. Rational English Language Cever Jownal, 28, $15-27$.

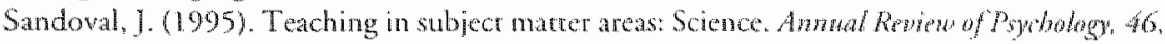
$355-374$.

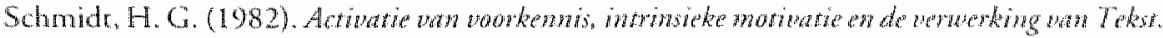
Academisch Proetschrift Universiteir Limburg, Apeldoorn: Van Walraven.

Schmide. H. G. (1983). Problem based learning: Rationale and descriprion. Medion Edantion. $17,11-16$.

Schmid, H. G. (1984). Activanic wan woorken nis en tekswerwerking Noderands Tijdobrift wor de Psychologits, 39, 335-347.

Schmidr, H. G., Spay, G., \& Grave, de W.S. (1988). Opsporen van misconceptics bij middelbare scholicten. Tijdschrift wer Onderwijsmeard, 13, 129-140.

Schmidt, H. G., De Volder, M.L., Grave, W.S. da, Mousc, J.H.C., \& Patd, V.L. (19)89). Explanarory modeds in the Processing of Science Text. The role of Prior Knowledge Activation Through Small-Group Discussion. foromal of Edhorionat Pydrology. \&/(4), 610.619

Schmidt, H. G. (1993). Foundations of problem based laming: Some explanatory nores. Medial Education, $27,422-432$.

Schmide, H. G. (1994). Resolving inconsistencies in turor expertise researdt: Docs lack of structure cause students to seek rutor guidance. Academic Modiche, 69(8), 656-662.

Schmid, H. G., Moust, J.H.C. (1995). What makes a tutor effective. A scructiral-equations modeling approach to leaning in problem-based curricula Acadonic Medisine $70(8)$, $708-714$

Schraw, G., Bruning, R. \& Svoboda, C. (1995). Sources of siruational interest. Jormat of Reading Behation, 27(1), 1-17.

Shucll, T. I. (1986). Cognitive conceprions of learning. Rewiew of Educationat Reseath. 56 (4), $411-436$.

Slavin, R. F. (1991). When and why docs cooperarive learning inclease acticventent? Theorerical and empirical perspectives. In $\mathbb{R}$. Herc-lidarowitz, \& $N$. Miller (lids.\},

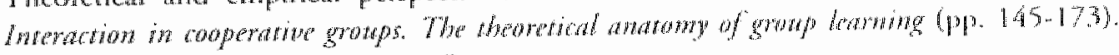
Cambridge: Cambridge University Press.

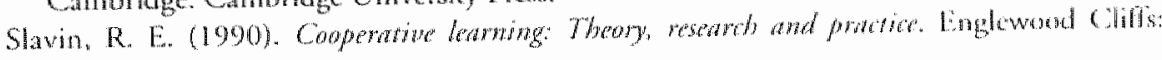
Prenrice Hatl.

Smith, J. P"., Dibessa, A.A., \& Roschelle, J. (1994). Misconceptions reconterved: A

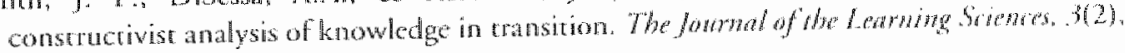
115-164.

Snow, R. E. \& Lohman, D.F. (1984). Toward a dueory of cognivive apticude for learning form instruction. Joumat of Eduational Pyohology, $760(3), 347-376$.

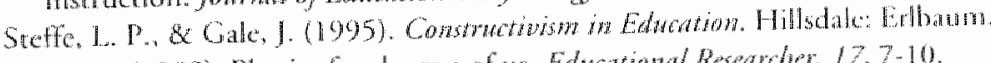

Strilcy, 1. (1988). Physics for the rest of us. Edwatromal Resermes, 17,7-10. 
Strodbe, W. \& Dich. M. (1994) Why groups are less efective than their members. On producriviy losses in idea-generaing groups. In. W. Srrobe \& $\mathrm{M}$. Hewsone (Eds.)

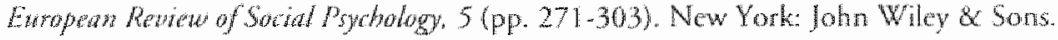

Thency, R. J., \& Cunningham, J. W. (1.984). Research on reaching reading comprchension. In P. D. Pearson (Ed.), Handbok of reading researh (pp. 609-655). New York Longman.

Van den Brokk, P., Flether C.R. \& Risden, K. (1993). Inwearigarions of inferential proceses in reading: A theoretical and methodological integration. Discows Processes, 16, 169-180.

Van Difk, T, A. \& Kintsch, W. (1984). Strategies of discourse compresonvon. New York. Academic Press.

Vedder. P. (1085). Cooperative Learning: A study on processes and effects of woperation benuech primary sobol childreth. "s Gravenhage: Stichring voor Onderzock van her Onderwijs.

Vosnadou, 5., B Brewer. W.F. (1987). Theories of knowledge resmuctung in dewdopment. Reviow of Eduational Rowath, 57,51-67.

Webb, N. M. (1989). Peer interaction and learning in small groups. Ihtemational jowmal of Edturatonal Reseated, 13, 21-41.

Webb, N. M. (1991). Task-related verbal interaction and mathematics leaning in small groups. Journal for Research in Mathematics Eduction, 22(5), 366-389.

Wobb, N. M. (1992). Tesring a theoretical model of student interaction and learning in small groups. In R. Herc-Laxarowizz \& N. Miller (Ed.), Interation in cooperation groups: The theortical anamy of groupleaming (pp. 102-120). New York: Cambridge Universivy Press.

Webb, N. M., Troper, J.D. \& Fall, R. (1995). Constructive activity and learning in collabonative groups. Jowryal of Edweational Psychology, $87(3), 406-423$.

Webb, N. M., \& Sulliwan-Palincsar, A. (1996). Group processes in the dassroom. In D. C. Berliner, \& R.C. Calloe (Gds), Handbook of educationat psychology (pp. 841-873). New York: Simon \& Schuster Macmillan.

Weinstcin, C. E., \& Mayer, R.E. (1986). The teaching of learning strategies. In M. C. Witurock (Ed). Handbook of reatuch on reaching (pp. 315-327). New York: Macmillan.

White, R. \& Gunstone, R. (1992). Probing suderstanding London: Falmer Press.

Wilson, P. T., \& Anderson, R.C. (1986). What they don "it know will hur them: The role of prior knowledge in comprehension. In $\mathrm{J}$. Orasana (Ed.), Reading comprebemion: From research to pratice (pp. 31-48). Hillsdale, N): Erlbaum.

Wong, E, D. (1993). Self-generated analogis as a rool for constucting and cvaluating

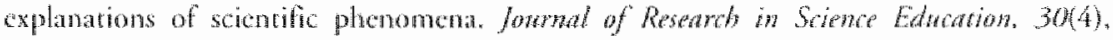
$367-380$.

Yinges, R. J. (1986). Examining thotght in acrion: A theorerical and methodological critique of

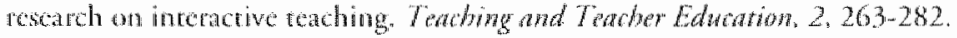

Znckerman, 1. T. (1994). Accurate and inacourate conceptions abour osmosis that accompanicd manuing ful problem solving. School Science and Marbematies. 94(5), 226234.

Zukcerman, J. T. (1994). Problem solvers conceptions about osmosits. The American Bralogy Thather, 56(1), 22-25.

Zuckerman, J. T. (1995). Une of inappropriate and inacenate concepual knowledge to solve an

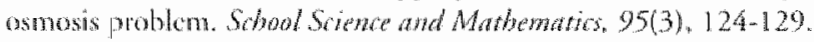




\section{Osmose en diffusie}

Osmose is her verschijnsel waarbij een sterkere oplossing water antrekt uir cen zwakkere oplossing, wanneer deze oplossingen gescheiden zijn door een half-doorlaatbare wand. Her Griekse woord 'osmos' betekent aanzuiging. De aanzuiging van watermoleculen kan tot stand komen door middel van diffusie (diffundere betekent uitbreiden).

Diffusie is een proces waarbij moleculen bewegen van een plaats met een hoge concentratie van die moleculen naar een plaats met een lage concentratie.

Stoffen xijn opgebouwd uit moleculen. De moleculen zijn niet statisch in de stof verankerd maar zijn steeds in beweging. In een vaste stof zitten de moleculen dichr op elkaar en kunnen daarom alleen op hun plaats heen en weer bewegen. In gassen en vloeistoffen zitten de moleculen zo ver van elkaar af dat ze vrijelijk, kriskras door elkaar heen kunnen bewegen. Ze botsen daarbij voorturend tegen elkat en tegen de wand van de ruimte waarin het gas of de vloeistof zich bevindt.

Diffusie in een gas treedt op wanneer zich op cen bepaalde plaats in een ruimte minder gasmoleculen bevinden dan op een andere plaats in die ruimte. Voorbeeld: in het scheikundelokaal van de school raakt een cilinder met waterstofsulfidegas lek, gas dat naar rotre eieren ruikt. Korte tijd daana stinkt de hele school. De moleculen die zich in grote getale in het scheikundelokaal bevonden op her tijdstip watrop de cilinder lek rakte, hebben zich door hun grote beweeglijkheid binnen korte rij over de hele school verspreid. Dexe verspreiding gaat zolang door roudar zich overal in de school dezelfde hoevecheid waterstofsulfide-moleculen bevinden (cussen de luchumoleculen in). In vloeisroffen zitten de molcalen nicr zo ver van elkaar als in gassen, maar kunnen zich toch door de hele vlocistof verplatsen. De moleculen in een vloeistol zitten zover van elkaar af dat andere moleculen 'ertussen kunnen kruipen'. We zeggen dan dat die moleculen in die vlocistofoplossen. Wanneer men suiker in water oplost, kruipen de suikermoleculen tussen de watermoleculen en er ontstaar een suikeroplossing. Her stukerklonge dat annvankelijk nog zich tbaar is, verdwijn na verloop wan tijd. De suikermoleculen bewegen van de bodem van het glas, waar ze in grote concencraric anwezig zijn, narar de rest van het water (lage concentratie). Dir gaat zolang door totdat zich overal in her water een gelijke hoevectheid suikermoleculen bevind; de suiker is nu homogeen over het warer verdeeld. 
We nemen aan dat we een bak hebben met in het midden een cussenschot; rechrs laten we er een suikeroplossing inlopen die op elke 98 moleculen water 2 moleculen suiker bevat, links een oplossing die op 90 moleculen water 10 moleculen suiker bevar. Als vervolgens het russenschor wordr verwijderd, zijn beide oplossingen nict meer gescheiden en kunnen er moleculen van links naar rechts en omgekeerd bewegen. In het grenswak zullen meer watermoleculen van rechts naar links bewegen (omdar er rechrs meer zijn) dan omgekeerd en meer suikermoleculen van links naair rechts dan omgekeerd. Na enige tijd is er rechts meer suiker en minder water gekomen en links ongekeed. Dit gaat zolang door totdat er rechts en links evenved watermoleculen en evenved suikermoleculen zijn, dus 94 moleculen water op 6 moleculen suiker. Dan gaan er van beide soorten moleculen evenveel naar rechts als naar links; er is evenwichr ingerreden, maar de moleculen blijven bewegen. Door diffusie zijn er gemiddeld meer suikermoleculen wan links naar rechts bewogen en moer watermoleculen van rechts naar links.

Diffusie komt dus tor stand vanwege het feit dat moleculen, en ook ionen, vrij in een vlocistof of in een gas kunnen bewegen. De energie voor deze beweging wordt geleverd door de moleculen of ionen zelf. Diffusie verloopt echter sneller naarmate: $a$. De temperatuur hoger wordt; als de temperatuur hoger wordt gaan de moleculen sneller bewegen, $b$. het concentratieverschil groter is; als het concentratieverschil groter wordr, bewegen er meer moleculen van de hoger naar de lagere concentratic, $c$ het oppervlak waal doorheen de molecullen diffunderen groter wordt; er kunnen meer moleculen per tijdseenheid van de hogere naar cle lagere concentratie diffunderen, $d$. de afstand watrover de moleculen moeten bewegen kleiner is: wanneer die afstand klein is wordt de evenwichtstoestand eerder bereikt. De diffusiesnelheid is bovendien nog afhankelijk van de aard van de moleculen, o.a. cle grootte van de moleculen; hoe groter het molecuul, hoe langzamer her diffundeert. De snelheid waarmee de evenwichtstoestand bereikr wordt, is afhankelijk van her feit of diffusic in een gas of in een vloeistof plaarsvindr. In een gas is die snetheid over het algemeen groter.

Diffusie speele bijna altijd een rol bij de opname of afgifte van stoffen, hetzij op het niveau wan de cel, hetzij op het niveau van het organisme. Bij cencellige organismen vindr opname van zuurst of en afgifte van kooldioxyde plaats door middel van diffusie. Datzelfde geldt ook voor meercellige organismen.

De half-doortatbare of semi-permeabele wand, die de begrenzing wormt van alle cellen, laat gewoonlijk alleen warer doot; stoffen die in dar water zijn opgelost kunnen her membran niet zonder meer passeren. De semi-permeabele membraan stat mer andere woorden dus van oplossingen alleen de vrije diffusie yan water toe. Stoffen die buten de cel in de oplossing aanwezig zijn kunnen niet in de cel mee diffunderen.

Als zich nu aan weerszijden van een semi-permeabele membraan verschillend geconcentreerde oplossingen van een stof in water bevinden, rreed ther volgende ver- 
schijnsel op: En diffundeert gemiddeld meer water van de kan wan de oplossing met de laagste concentratie wan opgeloste stoflen naar de kant van de oplossing mer de hoogste concentrarie dan omgekeed, doordat de waterconcentratie in de zwakste oplossing hoger is dan de waterconcentrarie in de sterkste oplossing. Daar de opgeloste stof niet mee kan diffunderen, wordt de sterke oplossing geleidelijk verdund en neemt deze in volume toe; de zwakke oplossing wordt stecds meer geconcentreed en neeme in volume af. Dit verschijnsel zer zich voort rordat beide oplossingen een gelijke concentratie hebben. We noemen dit asmose. Osmose kunnen we dus definiëren als de diffusic van water door enn semi-permeabele wand van een zwakkere naar een sterkere oplossing. We kunnen her verschijnsel op de volgende manier verklaren: Stel dat aan beide zijden wan een semi-permeabele wand een verschillende hoeveelheid suiker in water is opgelost. In de sterke oplossing is dar 20 suikermoleculen per 80 waremoleculen: in de zwakke oplossing is dat 5 suikermoleculen per 95 watermoleculen. Omdar moleculen alrijd in beweging zijn, zullen er steeds moleculen regen de semi-permeabole wand botsen. Van de 100 moleculen die aan de ene kant regen die wand botsen kunnen er maar 80 door die wand heen (namelijk de watermoleculen), wan de 100 moleculen die aan de andere wand tegen die wand botsen kunnen er echrer 95 doorheen. Er gaan dus in de uiterst korte tijd dat er aan weerszijden 100 moleculen borsen 15 moleculen meer van de zwakke nar de sterke oplossing dan er van de sterke naar de zwakke oplossing gaan. Dit osmotisch proces gat door tot beide oplossingen even sterk zijn, dat wil zeggen tor wan beide zijden evenveel watermoleculen door de wand gaan. Er is dan een evenwich bereikt. De volume toename die bij osmose optreed in de sterkste oplossing gaat gepaard met het opbouwen wan een bepaalde druk. Deze druk wordt osmotische druk genoemd. Deze druk is het gevolg van het verschil in waterconcentratie cussen de voeistoffen aan weerszijden van de membraan. De osmotische druk kan gemeten worden met behulp wan een zogenaamde osmometer. Dexe bestat wit een ruinre omgeven door een semi-permeabele membraan - de wand van een varksushlaas wordi hicrvoor gebruik - waarop cen stijgbuis is angesloten. Wannecr binnen de membran een stertke suikeroplossing gebrache wordt en de osmometer in een batkje me cen zwakke suikeroplossing gezet wordt, gaat de oplossing in de buis omhoog, omdar ic oplossing water anzungt. Dit opzuigen gaat niet eindeloos door want de vlocistofkolem in de buis oclent cen druk uit waardoor watemoleculen uit de varkensblas geperst woten. Ir ontstaat een evenwicht wanneer de anzuigende ktacht van do oplossing in de varkensblaas gelijk is an de tegendruk wan de wocistofkolom. De anaruigende kracho wan de sterkere oplossing kan nu uirged ruke worden in een bekende kracht, namelijk de druk van de vlociscolkolom. De druk van de vlocistofkolom is dus gelijk atan de aanzuigende of osmorische druk wan de sterkere oplossing. De ommotische druk wan een bepalde oplossing is maximal wanneer deze door eer semi-permeabete wand gescheiden is van zuiver water. Dere maximale osmotische druk wan de op- 
lossing wordr osmotische waarde genoemd. De osmotische waarde van een oplossing 1 ewenredig met de verhouding van het aantal opgeloste moleculen en/of ionen ten opzichte van het aantal watermoleculen.

Als twee oplossingen dezelfde osmotische waarde hebben, kan er geen osmose tussen deze oplossingen platsvinden; men noemt ze isotonisch ten opzichte van elkaar. (iso = gelijk, tonos = spanning). Als twee oplossingen een verschillende osmorische waarde hebben, dan is de oplossing mer de hoogste osmorische waarde hypertonisch ten opzichte van die met de laagste osmotische waarde, die hypotonisch is. (hyper = over, bovenuit, hypo = onder). Osmose vindt dan plaats van de hypotonische naar de hyperronische oplossing, mer andere woorden de hypertonische oplossing zuigt water aan uit de hypotonische oplossing.

Een cel bestaat uir een hoeveel heid vloeistof, het cytoplasma, warin zich een aantal celonderdelen, de celorganellen, bevinden. Het voornaamste celorganel is de kern, die noodzakelijk is voor her voorrbestaan van een cel. De cel wordr omgeven door een semi-permeabele wand, de membraan, ook wel cytoplasma genoemd. Een cel die zich in zuiver water bevind neemt door osmose water op. Het plasma binnen de cel is namelijk hypertonisch ten oprichre van her uirwendig milieu van de cel, in dit geval zuiver water. In het cytoplasma bevinden zich zouten en eiwitten dic de celinhoud een bepaalde osmotische warde verlenen. De cel zwelt tengevolge van de wateropname en zou daardoor kapor kunnen knappen. Bij planraardige cellen wordt dit woorkomen doordat deze cellen een celwand bezitten. De celwand is volledig doorlaten (permeabel) voor water en de daarin opgeloste stoffen. Andere cellen hebben ro'n wand soms nicr.

Een plantecel bevat tevens een speciaal celorganel, de vakuole. In deze vakuole zijn zouten, reservestoffen, afvalstoffen, zuren en kleurstoffen opgelost, waardoor de plantecel die osmorische waarde heefr. Wanneer een plantecel zich in een hypotonisch milieu (hypotonisch ten opzichte van de vakuole) bevind zal er door osmose water uit her milieu worden angezogen. Het water komt in de vakuole terecht en deze awelt daardoor. Omdar de vakuole groter worde is er in de cel minder plaats voor her cytoplasma en de overige celorganellen. Het cytoplasma mer de daarin zwevende celorganellen wordt steeds meer tegen de membean en daardoor ook steeds meer tegen de celwand angedrukt. Deze druk van de inhoud van de cel op de celwand wordt turgor genoemd. Naarmate er meer water door de cel wordt aangerogen, neeme de vakuole in grootte toe en neemt ook de druk waarmee het cytoplasma tegen de celwand aangeduwd wordt steeds meer toe. De celwand is enigszins elastisch en kan door de toenemende druk van binnen uir de cel enigswzins uitrekken. De totale cel wordt dan ook groter. De toename vindt voornamelijk in de lengterichting plaats. Op cen gegeven moment kan de celwand niet meer verder uitrekken. De osmotische waarde wan de cel is nog steeds zo hoog dat de vakuole-inhoud nog steeds hypertonisch is ten opzichte van her uirwendig milicu. De wateropname bliff dus doorgaan en de vakuole neemt nog meer in omvang 
toe. De druk op de celwand, uitgeoefend door de vakuole en her cytoplasma. neemt eveneens nog toe. Doordat de celwand niet verder kan uirrekken oefent deze een tegendruk uit, de zgn. wanddruk. De cel neemt dus nier meer in groorte toe wanneer de osmotische warde (warmee warer de of binnentreedt) even groot is als de wanddruk (waarmee water de cel wordt uitgedrukt). De spanning van de celwand als gevolg wan de turgor geeft de plantecel grote stevigheid. De stevigheid wan kruidachrige planten berust vrijwel geheel op de turgor.

Plantecellen zijn alleen in turgor zolang het vakuolevocht en het cytoplasma hypertonisch zijn ten opzichte van de oplossing buiten de cel. Deze oplossing kan de plant geheel omringen (waterplanter) of bevindr zich in de bodem (landplanten). De oplossing bevindt zich om elke cel doordat de poreuze, permeabele celwanden er geheel mee doordrenkt zijn. Als plantecellen door verdamping warer verliezen, wordt dit door osmose weer aangevuld. Bij landplanten gebeurd dit wanu it de worrels en bij warerplanten ook direct in de stengel en bladeren.

Wanneer het vakuolevocht door bijzondere omsrandigheden isoronisch zou zijn ten opzichte van her milieu warrin de cel zich bevindt, vindt er geen wateropname plaars en ontstaat ef geen surgor en daardoor ook geen wanddruk. De cel verlicst zijn stevigheid en wordr slag en kleiner omdat de celwand nier uitgerekr is.

Komt de cel in een hypertonisch milieu dan word er geen water uir het milieu aangezogen door de cel, mar wordt er door her milieu water angezogen uit de cel. De cel krimpt daardoor nog verder. De wakuole wordt zo klein dat het cytoplasma niet meer tegen de celwand aangedrukr wordt. Wordt de vakuole nog kleiner dan laat her cyroplasma los van de celwand (plasmolyse). De vakuole mer daaromheen het cyroplasma lige nu geheel los van de celwand en de cel heefi alle stevigheid verloren. Deze toestand kan weer ongedaan gemaakt worden door de cel weer in een hypotonisch milieu te brengen (zuiver water) mits de plasmolyse niet al te lang duurt. 



\section{Regulatie van de bloeddruk}

De primaire functie van her circulatiesysteem is de voorzieningen te leveren voor weefsel metabolisme en groei on de producten van metabolisme te verwijderon. On te verklaren hoe het hare en de bloedvaten deze funcrie dienen is her noodzakelijk om het systeen morfologisch en funcrioneel te analyseren en de mechanismen van de component delen in hun bijdrage tor her handhaven van adequate weefseldoorbloeding onder verschillende fysiologische condities. Wanneer de functies van de verschillende onderdelen zijn begrepen is het essenticel dat hun interrelaties in de algemene rol van her circulatiesysteem worden beschouwd. Weefseldoorbloeding is afhankelijk van arteriele druk en locale vasculaire weerstand en arceriële druk is weer aflankelijk van hartminuurvolume en torale perifere weerstand. Arteriële druk wordt gehandhaafd binnen een relatief kleine reikwijdte in het normale individu, een kenmerk dat wordt bereik door de wedekerige veranderingen in harminuurolume en totale perifere weerstand. Hartminuatvolume en perifere weerstand worden echter elk beinvloedt door een aantal factoren en her is de wisselwerking tussen deze factoren die het nivo van deze twee variabelen bepaald. Her autonome zenuwstelsel en de baroreceptoren spelen de sleutcliol in het reguleren van de bloeddruk. Echter vanuit het standpunt van de lange termijn is de controle van vloeistof-evenwicht door de nier, adrenale cortex en centrial zenuwsysteem, met daarbij het handhaven van een consant bloed volume van het grootste belang.

In deze tekst worden achterecnvolgens de volgende onderdelen wan her circulaticsysteem behandeld. Allereerst worde dieper ingegaan op de verschillende componenten van her vaatstelsel. Vervolgens wordt ingegaan op de factoren dic her hartminuurvolume bepalen. Daarna kome de regularie wan de bloeddruk aan de orde waabij voon ingegan wordt op de korte temijn regulatic. Tenslotre wordt anafylactische shock behandeld.

Druk en stroming in het vaatstelsel; hemodynamica

Het bloed stroomt in het vaatselsel onder invloed van een drukverschil. Dit drukverschil $(\Delta P$ ) word hoofdzakelik door de werking van her hart maar ook door krachren van extra carcliale oorsprong gethandhaafd. Bloed stroome nar cen plaats 
met cen lagere druk. Om de stroomsncheid (F) te kumen bepalen met men echter weten wat de weerstand $(R)$ is wartegen het bloed in moet stromen. De wolgende formulc is hicrop van roepassing:

$$
F=\frac{\Delta P}{R}
$$

De weerstand wordt bepaald door de factoren:

1. viscositerit van de vloèst of. As de viscositeit van de vloeistof groter is dan ondervind de stromende vloeistof meer weerstand.

2. De wijde van de vaten. Hoe wijder de vaten des te lager de weerstand. In het vaatstelcel is de wand elastisch, d.w.z. door verhoging van de druk in her vat kan de diameter vergroot worden.

Het volume van de vlocistof in het vatstelsel behoeft dus nier alrijd dezelfde te zijn; en groter volume bloed kan in het vatstelsel opgeslagen worden door de wand wir re rekken. (compliance/rekbaarheid: de mate van volumeroeneming bij) een bepaalde drukstijging).

\section{Drukverval in het vaatstelsel}

De eigenschappen van artericu, capillairen en venen zijn onderling sterk verschillend. Men kan het vaatstelsel opgebouwd zien uit 3 in serie geschakelde compartimenten: arterieel deel, weefselcompartiment en veneus deel. De weerstand die dit vaatstelsel biedt aan thet stromende bloed noemt men de perifere weerstand. De druk en stromingsverhoudingen in deze drie comparrimenten verschillen van $\mathrm{el}$ kaar.

\section{Compartument 1: arterieel stelsel}

Her arterielle stelsel kan men woorstellen als cen grote rekbare buis, het analogon van aorta cn grotc anterièn. Deze buis heef aan haar ene einde het hart, dat bloed in de buis pompt, an thet andere cinde bevindt zich een vernauwing, die in feite gevorma wordt door de gezamenlije arteriolen; de weerstand die dere vernauwing bied atan het uit de buis stromende bloed vormt de belangrijkste component van de perifere weerstand.

De antericle bloedstroom: Gedurende cen korte tijd wordt er pulsarief door het harr cen hoeve theid bloed (slagvolume $=\mathrm{ca} .80 \mathrm{ml}$ ) in her arterelle stelsel gepompr. Door de rekking wan de vatwand kan het inwendig volume zodanig vergroor worden dar het gehele slagvolume in het artericel deel opgeslagen zou kumen worden. In werkelikheid zal dir nier gebeuren ondat dar nijdens de ejecriefase alle arteriolen gestoton zouden moeten zijn. Er zal steeds een uitstroming van bloed zijn die veel gelijlimatiger is dan de instroom. Dour de rekbarheid van het arterièle stelsel wordt de discontinue instroming omgezer in ex continue uitstroming. 
De instroming van bloed rijdens de ventrikelsystole veroorzakt een rekking van het arteriäle warstelsel waardoor de spanning in de wand wan de arteric roeneemt. Hierdoor srijgt de druk in dit deel van her watsrelsel. De hoogse druk die hierbij optreedr is de systolische druk. Tijdens de diastole van de ventrikel stroomt geleidelijk bloed af door de perifere vatern. Her volume van her arreriële stelsel worde kleiner, daardoor neeme de rekking en daarmee de spanning wan de wand af. De druk in het arterielle stelsel is her laagst vlak voor het moment dat er cen nicuw volume bloed ingepompt wordt. Dir is de diastolishe druk. In rust is de systolische druk $120 \mathrm{~mm} \mathrm{Hg}$ en de diastolische druk $80 \mathrm{~mm} \mathrm{Hg}$. Het verschil in syscolische druk en diastoliche druk wordt polsdrukgenoemd. De hoogre van de sysrolische en diastolische druk is afhankelijk van een aantal factoren. Voor de lunktie van her arteriële stelsel als distriburieapparaat van bloed voor de verschillende lichaamndelen is echter de gemiddelde druk belangrijker dan de maximum (systolische) en minimum (diastolische) waarde.

De hoevelheid bloed die per tijdseenheid, bijv. per minuut het anteriele stelsel binnenkomt is het product van slagvolume en frequentie: het $x$ g. minuurvolume. De thoogte van de gemiddelde arteriële bloeddruk is afhankelijk van hot minutvolume en de perifere weerstand. De perifere weerstand kan gedefinicerd worden als de weerstand die her bloed ondervind bij de stroming door her vatstelsel; 75 $\%$ hiervan wordt geleverd door de arteriolen $(50 \%)$ en capillairen (25\%). Capillairen zijn over het algemeen niet in serie, maar in parallel geschakelde dententen.

De totale weerstand van parallel geschakelde elementen is alcijd lager dan wan een van de componenten.

Facroren die de bloeddruk bepalen: Factoren die de systolische en diastische druk bepalen zijn:

a. Slagvolume: Naarmate het slagvolume stijgr worde bet verschil uissen diastolische en systolische druk groter.

b. Frequentie: As de frequicntie stiggt, neemt de diastolische druk roe ondat er minder tijd woor is voor her wegstromen van bloed uit de groteaterien. Her effect op de systolische druk hange af van de verandering dic he slagvolume cegelijkerrijd heef ondergan.

c. Snetheid van de ejectie (duur ejecricfase): Als de snctheid worde vergroor zonder dat her slagvolume roeneemt, treedt een verscherping van de polsgoll op, wandoor de systolische druk srigg en de dialstolische druk datatu.

d. Perifere weerstand: Verhoging van de perifere weerstand verhoog de diastolische en systolische druk in gelijke mate.

e. Rekbaarheid van het arterièle varstelsel: Als gevolg van het ouder worden neemt de rekbaarheid van het artericel srelsel af. Lenzelfde volume vergrowing geef dardoor een stenkere druksrijging, de systolische druk word daardoner werhoggd. De snellere afstroming naar het capillare stelsel dic hierwan het gevolg is, zal kun- 
nen voeren tot een verlaagde diastolische druk. In elk geval neemt de polsdruk sterk toe.

f. Vulling wan her arteriele vatstelsel: Verhoging van de wulling van her gehele vaarselsel heef vele gevolgen die op gecompliceerde wijze de bloeddruk beïnloeden. In principe geefr verhoging van de vulling een toeneming van zowel diastolische als syscolische druk in de arteriën. Een grotere vulling van het vaarstelsel zal echter doorgaans gepaard gaan met een groter slagvolume; de combinatie van beide matakt dat systolische en diastolische druk beide stiggen, maar de systolische druk meer dan de diastolische.

g. Viscositeit wan het bloed: Verhoging van de viscositeir van het bloed veroorzaakt en een hogere perifere weerstand.

Deze factoren zullen slechts zelden geisolleerd optreden. Bloeddrukverandering is daarom her product van een aancal. samenwerkende factoren.

Compartiment 2: Microcirculatie.

Onder microcirculatie verstat men het gedeelte van de bloedsomloop dat niet met her ongewapende oog zichtbaar is. In dit gebied vindt de uirwisseling plats van stoffen en warmte tussen bloed en weefselvocht.

De microcirculatie wordt gewormd door een sterk verakkend netwerk van zeer dunne vaajes (arteriolen, voorkeurskanalen, capillairen, wenulen). De totale doorsnede van thet vatstelsel wordt naar de periferie steeds groter. Dit maakt dat de stroomsnelheid over korte afstand zeer sterk afneemt. In de capillairen is deze snelheid zeer klein, zodat voldoende tijd voor cen redelijke mate van uitwisseling is. "Tijdens de passage door de microcirculatie is er slechts een gering drukverval, omdat als gevolg van de vele parallelschakelingen de totale weerstand gering is.

Compartiment 3: Veneus deel.

Het vencuze stelsel is anzienlijk groter wan wolume dan het arteriele stelsel, de venen bevarten onder normale omstandigheden ca. $75 \%$ van her toraal circulerend bloedvolume. Devenen vormen her belangrijkste bloeddepot. Omdar ook de venen gladde spiervezels bevatten die $\alpha$-adrenerg geinnerveerd zijn, kan een wernauwing van de venen opreden: venocontrictie. Dit heeft tot gevolg dat meer bloed beschikbar komt voor het arterièle en capillaire deel van de circulatie.

Vencuxe terugstroming: De stroming van het bloed in de venen is slechts gedeeltelijk her gevolg van de werking van het hart; daarnaast zijn verschillende extracardiale faktroren onmisbaar om een terugstroom wan bloed natar het hart, de veneuze terugstroom tot stand te brengen, die sterk genoeg is. 


\section{Regeling van de hartprestatie}

(factoren die de rwee determinanten van harminuurolume, harfrequentic en slagvolume bepalen,

De belangrijkste mat voor de harprestatic in vivo is her minuurvolume, de hoeveeheid bloed die rijdens een minur door een sentrikel wordt uirgepompt. Het slagvolume is de hoevectheid bloed die per slag door een wentrikel word uitgepompt. Het minuruolume is dus her product van her gemiddelde slagvolume en de harrfrequencie, uitgedruk in slagen per minuur.

De harffrequentie word geregeld door intrinsicke mechanismen en extrinsieke mechanismen. Onder intrinsieke mechanismen worden mechanismen verstan die nier onder invloed van hormonen of zenuwen platswinden. Onder extrinsieke verandering verstaat men een verandering van de hartrequentic die tor stand komt als gevolgr van een gebeurtenis elders in het lichaam. De exrrinsieke regulering geschiedt op rwee verschillende wijzen:

a. Nerveus: Via de zenuwen die onderdeel uirmaken wan her vegenatieve zenuwstelsel, gaan impulsen naar her har die, afhankelijk van de herkomsr van de vezels, de frequentie in negatieve dan wel in posicieve zin lsumen beimvlocden. Een negarieve invloed, d.w.z. en frequentieverlaging wordo tot stand gobracht door het parasympatische deel van her vegeatieve zenuwstelsel via de nn.vagi. Een posirieve invloed, d.w.z. cen frequentieverhoging komt tor stand door hret orthosymparische deel van het autonome zenuwstelselvia de mn. accelerantes.

b. Door middel van in het bloed voorkomende stoffer kan de hartrequentie worden beinvloed: Dit betref vooral hormonen, in het bijzonder adrenaline uir de bïniermerg.

De tweede variabele die de harrvolume bepaald is her slagyolume. Tijelens contractie ledigen de ventrikels zichzelf nooir volledig van bloed. Daarom kan een meer krachrige contractie cen toename in stagvolume produceren.

Veranderingen in contracriekrach kunnen worden geproducect door en vorscheidenheid aan factoren mar er zijn twee dominan onder de meeste fysiologische condities:

1. veranderingen in het einddiastolische volume, dat wil reggen het wolemen van bloed in de ventrikels juist voor de contractic. (intrinsick mechanisme) on

2. veranderingen in de groote var sympatische zenuwstelsel input in de ventrikels (extrinsick mechanisme).

Wat her cerste punc betreft: Door bijwoorbeetd wergrote veneuze toevoer stigg de druk in de atria en ventrikels sneller tijdens de diastole; de cinddiastolische druk in het hart is dardoor hoger. Hierdoor zal het hart an het cind van de dasmole meer gevuld zijn, dus meer gerekt. De spiervezels hebben een grotere voorspanning (eng.: preload) gekregen waardoor de lengte is toegenomen. Doon de grotere vezel- 
lengte is de contractiekracht vergroot en wordi dus meer uitgepompt (slagvolume). War het rweede punt betreft:

Ook door sympatische activiteit verhoogt de contracriliteit (gedefinieerd als de sterkte van contractic bij elk gegeven einddiastolisch volume). Verder verhoogr ook adrenaline de contractiliteir wan het hart.

\section{Korte termijn regulatie van de bloeddruk}

In de medulla oblongata (formatio rericularis) bevinden zich de centra voor de regulatic van hart en vaten. Her orthosympatisch zenuwstelsel heeft een bloeddrukverhogende werking, de n.vagus (parasymparisch) heeft een bloeddrukverlagende werking. Vanuit de centra wordt de activiteit van de sympaticus en de parasympaticus bepaald. In rust zijn zowel de sympaticus als de parasympaticus acrief: er heerst een zekere sympaticotonus en een vagotonus. In rust overheerst de invloed van de n. wagus op het hart, de vaten worden uitsluitend sympatisch geïnnerveerd. De centra ontvangen continu informarie over de hoogte van de bloeddruk uit de barosensoren. De barosensoren bevinden zich in de wand van de aorra en de a. carotis (sinus aorricus en sinus caroticus). Deze sensoren zijn gevoelig woor rek van de vaatwand en worden dus gestimuleerd bij verhoging van de bloeddruk De acrieporentialen lopen via afferente vezels, de n. glossopharyngeus en de n. vagus. Deze hebben een remmende werking op de centra. Hierdoor neemt de vagotonus woe en de symparicotonus af. De centra bepalen dus door verandering in de vagoen sympaticotonus de hoogte van de bloeddruk op geleide van de barosensoren. Bij een plotselinge bloeddrukverlaging (bijw. opstan) neemt de remming op de centra af. Hierdoor neemt de vagotonus af en de sympaticotonus toe. De gevolgen voor het vaatsysteem kunnen van boven naar beneden worden afgelezen:

i. de hartfrequentie en contractiliteit nemen toe zodat het harminuturvolume. stiiggt.

2. er ontstatat arteriolenconstrictie zodat de perifere weerstand roeneemt.

3. door venoconstrictie verplaarst her bloed zich naar de arterièn.

4. de bloeddepots verkleinen zodat het circulerend volume toeneemt. Dere reflexen worden gededtelijk ondersteund doordat ook het bijniermerg worde gestimuleerd tot adrenaline secretie. Door al deze facroren wordt de bloeddrukdaling ongedaan gemaakt. De werking via zenuwen (snel) maakt dit systeem bij uitstek geschikr om snclle bloeddrukveranderingen het hoofd te bieden. Het feedbacksysteem voor de bloeddrukregulatie is dus opgebouwd uit de volgen de basiscomponenten:

1. barosensoren: vertaling van de bloeddruk in neurale activiteir.

2. afferente wezels: geleiding van de neurale activiteit naar de centra.

3. de centra: de heersende waarde wordt vergeleken met de gewenste waarde (instelwaarde). 
4. de efferente vezels: geleiding van her correcriesignaal.

5. effectororgaan: uivoering van de cortectie door hart en vaten.

Via dit systeem word in rust een gemiddelde bloeddruk van ongeveer $100 \mathrm{mmHg}$ gehandhaafd. Bij arbeid en emories word de instelwarde van her blocddrukregualriesysteem gewijzigd zodat gestreefd worde naar een hoger bloeddruknivo. Deze invloed komt rot stand wia hogere hersencentra: cortex cerebri, limbisch systecm en hypothalamus.

Daarnaast zijn er ook invloeden wan chemosensoren: de perifere bevinden zich in de wand van de aorra en a. carotis, de centrale liggen aan de ventrale zijde van de medulla oblongata. Ze zijn gevoelig voor een stijging van de $\mathrm{pCO}_{2}$ of een daling van de $\mathrm{pO}_{2}$ of van de $\mathrm{pH}$. Door deze veranderingen worden de centra gestimuleerd en stijgt de bloeddruk.

\section{Anafylactische shock}

Anafylactische shock is een allergische conditie warin het hartminuurvolume en de arteriële bloeddruk sterk verminderen. Een anafylactische shock kan bijwoorbeeld ontstaan na een bijensteek. Anafylactische shock is het gevolg van een immunologische reactie (antigeen-antilichaam) waarbij basofielen in het bloed en de mestcellen in de pericapillaire weefsels histamine vrij maken. Histamine veroorzaakt:

1. Veneuze dilatatie en daardoor een vergroting van de vasculaire capaciteit.

2. Dilatatie van de arteriolen met alls gevolg een sterk verlaagde arrericle bloeddruk.

3. Sterk verhoogde capillaire permeabiliteit met een snel verlies aan vocht en eiwitten naar de interstitiële ruimten.

4. Een toxische werking op de hartspier.

Her totaal effect van shock is een sterke reducric van de veneuze terugstroming waardoor hartminutwolume en arteriële bloeddruk verlagen. Shock kan zo'n enstige bloeddrukdaling ror gevolg hebben dat de dood crop volgt. Bij anafylacrische shock staat infusiecherapie voorop: in de initiêle fase kunnen intraveneus adrenaline en antihistaminica worden toegediend. 



\section{Dankwoord}

Dit proefschrift is voortgekomen uit mijn deehame an het COMOFA-project. Dit onderzoeksproject onderzocht de cognitieve en motivationele aspecten van probleemgesruurd leren. In dir project participeerden verder Jan Belièn, Jos Moust, Maurice de Volder, Henk Schmidr en Bere Kerkhoffs. In dit project is mijn interesse in her probleengestuurd leerproces en het onderzoek daarvan gewekt. Door de jaren heen is deze interesse toegenomen. Uireindelijk heeft dir geresulteerd in een proefschrift. Mijn dank gaar dan ook allereerst uit naar de participanten van dit onderzoeksproject.

Het realiseren van een proefschrift is her resultat van samenwerking cussen velen. lk wil hier dan ook mijn dank betonen aan de personen warmee ik heb samengewerkt.

Allereerst wil ik Henk Schmidt en Els Boshuizen, respectievelijk mijn promoror en co-promotor, bedanken voor hun begeleiding bij het tot stand komen van dit proefschrift. Hun adviezen en correcties waren zeer waardevol. Tk heb ved wan hen geleerd.

De experimenten en andere onderzoeken in dit proefsclurift zijn uitgevoerd in nauwe samenwerking mer een aantal studentassistenten en studenten. Zonder degenern die nier genoemd zijn te kort re willen doen wil ik voor de plezierige en goede samenwerking vooral bedanken: Petra van der Berg, Klaas Boonstra, Leon Dingelstad. Hedy Folkersma, Branca Grotenhuis, Iris Höppener, Helen Koch, Ronald Linden, Lidwien Maas, Yronne te Riele, Anne-fileur van Rootselaar en Dankert Woutersen.

Een stimulerende werkomgeving is een belangrijke voorwarde voor her pealiseren van cen proefschrift. Ik wil dan ook mijn collega"s van de vakgrocp Onderwijsontwikkeling en Onderwijsresearch bedanken voor het creeren van zo'n goede werkomgeving. In het bijzonder gelde dit voor de collega's die werkzan zijin woor de Faculreit Geneeskunde.

Tenslorte wil ik mijn gezin noemen. Er is niets stimulerender dan een herrijk gezin. Ondanks de soms hectische toestanden was her cen oase van rust, relativering en inspiratie. Dineke bedankt voor je geduld en ondat je her mij mogelijk maakte om aan het proefschrift re werken. Linda, Laura, Joris, Niels en Lars ik ben trors op jullie.

Willem de Grave

Juni 1998 



\section{Curriculum vitae}

Willem Simon de Grave werd geboren op 19 augusrus 1949 te Leeuwarden.

$\mathrm{Na}$ her afsluiten van de ULO studeerde hij aan de Pedagogische Academic "Marienburg" te Leeuwarden, waar hij in 1971 zijin diploma volledig bevoegd onderwijzer behaalde. In 1972 startte hij met de studie Onderwijskunde an de Rijksuniversiteit Gromingen. Gedurende de doctoraalfase werkte hij enige cijd als studentassistent wetenschapsfilosofie ten behoeve van het studieprogramma Onderwijskunde. In 1979 behaalde hij het docroraal diploma Onderwijskunde (cum laude). Daarna werkte hij als wetenschappelijk medewerker aan het Research Instituut voor het Onderwijs van het Noorden (RION) te Haren (Gr.). Vanaf 1981 is hij als universiair docent werkaam bij de valkgroep Onderwijsontwikkeling en Onderwijsresearch van de Universiteit Maastricht. Tot 1983 was hij werkzaam voor de toen startende Faculteit der Gezondheidswetenschappen, daarna voor de Faculteit Geneeskunde. Zijn speciale aandachtsgebied is de professionalisering wan docenten. 